\title{
Development of a Dedicated Ethanol Ultra-Low Emission Vehicle (ULEV)-Phase 2 Report
}

L.G. Dodge

G. Bourn

T.J. Callahan

D.W. Naegeli

K.R. Shouse

L.R. Smith

K.A. Whitney

Southwest Research Institute

San Antonio, Texas

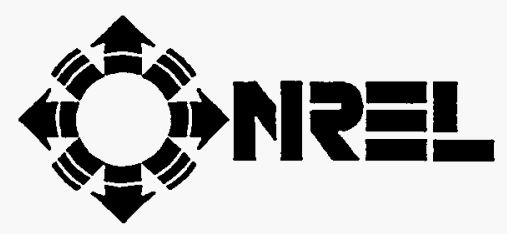

National Renewable Energy Laboratory 1617 Cole Boulevard

Golden, Colorado 80401-3393

A national laboratory of the U.S. Department of Energy Managed by Midwest Research Institute for the U.S. Department of Energy

Under Contract No. DE-AC36-83CH10093 


\section{NOTICE}

This report was prepared as an account of work sponsored by an agency of the United States govemment. Neither the United States government nor any agency thereof, nor any of their employees, makes any warranty, express or implied, or assumes any legal liability or responsibility for the accuracy, completeness, or usefulness of any information, apparatus, product, or process disclosed, or represents that its use would not infringe privately owned rights. Reference herein to any specific commercial product, process, or service by trade name, trademark, manufacturer, or otherwise does not necessarily constitute or imply its endorsement, recommendation, or favoring by the United States govemment or any agency thereof. The views and opinions of authors expressed herein do not necessarily state or reflect those of the United States government or any agency thereof.

Available to DOE and DOE contractors from:

Office of Scientific and Technical Information (OSTI)

P.O. Box 62

Oak Ridge, TN 37831

Prices available by calling (615) $576-8401$

Available to the public from:

National Technical Information Service (NTIS)

U.S. Department of Commerce

5285 Port Royal Road

Springfield, VA 22161

(703) $487-4650$ 


\section{Development of a Dedicated Ethanol Ultra-Low Emission Vehicle ULEV-Phase 2 Report}

L.G. Dodge

G. Bourn

T.J. Callahan

D.W. Naegeli

K.R. Shouse

L.R. Smith

K.A. Whitney

Southwest Research Institute

San Antonio, Texas

NREL technical monitor: C. Colucci

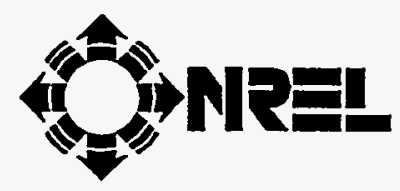

National Renewable Energy Laboratory 1617 Cole Boulevard Golden, Colorado 80401-3393

A national laboratory of the U.S. Department of Energy Managed by the Midwest Research Institute for the U.S. Department of Energy

Under Contract No. DE-AC36-83CH10093

Prepared under Subcontract Number YAW-3-12243-01

September 1995

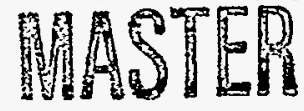




\section{Preface}

This work was conducted by Southwest Research Institute (SwRI), San Antonio, Texas, under Subcontract No. YAW-3-12243-01, SwRI project number 03-5901 for the U.S. Department of Energy (DOE) in Washington, D.C., and the National Renewable Energy Laboratory (NREL) in Golden, Colorado. The contributions of technical monitors Christopher P. Colucci and Brent K. Bailey of NREL, John A. Russell and John Garbak of DOE, and subcontract administrators Ernest G. Oster and Brian Rieper of NREL are gratefully acknowledged. The expertise of Ms. Jo Ann Brown in preparing this report is also greatly appreciated.

The objective of this 3.5-year project is to develop a commercially competitive vehicle powered by ethanol (or an ethanol blend) that can meet California's ultra-low emission vehicle (ULEV) standards and equivalent corporate average fuel economy (CAFE) energy efficiency for a light-duty passenger car application. The definition of commercially competitive is independent of fuel cost, but does include technical requirements for competitive power, performance, refueling times, vehicle range, driveability, fuel handling safety, and overall emissions performance.

This report summarizes the second phase of this project, which lasted 12 months. This report documents two baseline vehicles, the engine modifications made to the original equipment manufacturer (OEM) engines, advanced aftertreatment testing, and various fuel tests to evaluate the flammability, lubricity, and material compatibility of the ethanol fuel blends. 


\section{Executive Summary}

Ethanol is attractive as an alternative fuel for spark-ignition engines for a variety of reasons. First, it is a renewable fuel, derivable from biomaterials. Many alternative fuels are derived from petroleum, and their long-term potential is therefore limited by the availability of petroleum. Second, ethanol has an average octane number $((\mathrm{R}+\mathrm{M}) / 2)$ of about 106 , compared to about 87 for regular grades of gasoline. The higher octane number implies greater resistance to knock, which allows for higher compression ratios that produce greater cycle (and therefore fuel) efficiency. Third, because ethanol is derived from biofuels, there is arguably no net increase in greenhouse gases. This is in sharp contrast to petroleum-fueled vehicles, and especially natural gas-powered vehicles that typically have low nonmethane hydrocarbon emissions, but high emissions of methane, a significant greenhouse gas. Fourth, ethanol is nontoxic, unless toxins are added to prevent human consumption. Fifth, the fuel is naturally low in evaporative emissions, although in practice this potential advantage is offset with the addition of gasoline additives to increase the vapor pressure for starting and fuel tank safety. Sixth, the reactivity factor (potential for exhaust products to form ozone) for ethanol is significantly less than for gasoline, with preliminary estimates being about 0.68 (Marshall 1994) that of standard gasoline. Seventh, the principal emissions are unburned ethanol and acetaldehyde, formed in the first oxidation step of ethanol, which make a simpler mix of gases that must be treated in the exhaust catalyst than those produced by gasoline combustion.

Ethanol also presents engineering challenges that are present with any new fuel. For ethanol, lowtemperature cold-starting and fuel tank flammability are problems. The energy content of ethanol is about $63 \%$ that of gasoline, which decreases range or increases fuel tank size. Current ethanol costs are high enough to make it noncompetitive with gasoline, although encouraging cost reductions are being obtained.

Southwest Research Institute has been contracted by DOE and NREL to develop a dedicated ethanol- or ethanol-blend-fueled ULEV. This vehicle must be competitive with conventional gasoline-powered vehicles in cost, reliability, and performance, but not in fuel cost.

Southwest Research Institute proposed to make changes in the engine and aftertreatment systems of a standard OEM production vehicle to increase its efficiency and simultaneously reduce its emissions to ULEV standards. The vehicle platform selected for these modifications was the 1993 Ford Taurus flexible fuel vehicle (FFV) designed to operate on M85 and gasoline, and equipped with the 3.0-liter Vulcan engine. Selecting a vehicle that had materials compatible with both methanol and gasoline resulted in no material compatibility problems with ethanol fuels. The Ford FFV was the only U.S.-made FFV readily available when the vehicles were purchased. Two vehicles were purchased so that simultaneous testing of the engine modifications and the advanced aftertreatment devices could be conducted.

Three major changes to the engine were described by Bourn et al. (1994), and all three have been completed in Phase 2. These include increasing the compression ratio of the engine from 9.3 to 11.0 to take advantage of the high octane number of ethanol blend fuels, changing the fuel injectors to fine-spray air-assist injectors, and using a SwRI rapid prototype engine control system engine controller (RPECS) to provide more precise air-fuel ratio control and to control the aftertreatment system.

Although several advanced aftertreatment devices will be evaluated during this project, only electrically heated catalysts (EHCs) were scheduled for preliminary evaluation during Phase 2. Although the baseline vehicle emissions were quite low, adding the EHC to the standard unmodified OEM vehicle further reduced exhaust emissions. All tests were conducted with a vehicle mileage of about 4,000 miles, with the catalysts aged as described in this report. Carbon monoxide was reduced about $53 \%$ from the baseline vehicle to 
vehicle to $0.80 \mathrm{~g} / \mathrm{mi}$, about one-half the ULEV standard of $1.7 \mathrm{~g} / \mathrm{mi}$ at 50,000 miles. Nitric oxide was reduced about $12 \%$ from the baseline vehicle to $0.068 \mathrm{~g} / \mathrm{mi}$, or less than one-half the ULEV standard of $0.2 \mathrm{~g} / \mathrm{mi}$ at 50,000 miles. Nonmethane organic gases (NMOGs) estimated from hydrocarbons were reduced $49 \%$ from the baseline vehicle to about $0.052 \mathrm{~g} / \mathrm{mi}$, close to, but higher than the $0.040 \mathrm{~g} / \mathrm{mi}$ NMOG standard. Catalyst aging factors are not available for this aftertreatment system, but emissions measured at 4,000 miles are presumably significantly less than the ULEV standards for 50,000 miles to account for catalyst degradation.

During Phase 3, the engine control system will be developed sufficiently to provide reliable lowtemperature cold starts and produce very low engine-out emissions. Also during Phase 3, other advanced aftertreatment systems will be evaluated. 


\section{List of Abbreviations}

\section{Abbreviation Description}

\begin{tabular}{|c|c|}
\hline AMA & Automobile Manufacturers Association \\
\hline ASTM & American Society for Testing and Materials \\
\hline BOCLE & Ball on Cylinder Lubrication Evaluator \\
\hline CAFE & corporate average fuel economy \\
\hline DOE & U.S. Department of Energy \\
\hline DSP & digital signal processor \\
\hline ECU & engine control unit \\
\hline $\mathrm{EHC}$ & electrically heated catalyst \\
\hline FID & flame ionization detector (for hydrocarbons) \\
\hline FIDHC & hydrocarbons measured by flame ionization detector \\
\hline FIDRCH 4 & FID response factor for methane \\
\hline FIDRETH & FID response factor for ethanol \\
\hline FFV & flexible fuel vehicle \\
\hline FTP & U.S. federal test procedure (light-duty, for emissions testing) \\
\hline IMEP & indicated mean effective pressure \\
\hline LEV & low-emission vehicle \\
\hline LFE & laminar flow element \\
\hline MAF & mass air flow \\
\hline MBT & minimum timing advance for best torque \\
\hline $\mathrm{ms}$ & milliseconds \\
\hline NMHC & hydrocarbons excluding methane \\
\hline NMOG & nonmethane organic gases \\
\hline NREL & National Renewable Energy Laboratories \\
\hline OEM & original equipment manufacturer \\
\hline PEI & Petroleum Equipment Institute \\
\hline PW & pulse width \\
\hline RAF & reactivity factor \\
\hline RPECS & rapid prototyping engine control system \\
\hline RVP & Reid vapor pressure (at $100^{\circ} \mathrm{F}$ ) \\
\hline SMD & Sauter mean diameter \\
\hline SwRI & Southwest Research Institute \\
\hline TDC & top-dead-center \\
\hline TESS & Trajectory and Evaporation of Spray Systems \\
\hline TLEV & transitional low emission vehicle \\
\hline ULEV & ultra-low emission vehicle \\
\hline UNLG & unleaded gasoline \\
\hline$\mu$ & crom \\
\hline
\end{tabular}




\section{Overall Project}

This report summarizes progress made toward developing an ethanol-fueled ULEV. The effort was divided into six tasks, and the progress is reported separately for each task. However, a few items were not specific to one task and are discussed in this section.

\section{Vehicle Platform Choice}

As discussed by Bourn et al. (1994), a 1993 Ford Taurus FFV was chosen for modification to meet ULEV standards. The logic for choosing this vehicle was as follows. First, a significant amount of work has gone into developing materials suitable for use with alcohol fuels. This is especially true for fuel tanks, fuel pumps, fuel lines, and fuel injectors, all of which are typically of different materials than for many standard gasoline-fueled vehicles. Instead of working to redevelop these materials, the decision was made to choose a vehicle designed to be operated on alcohol fuels. In the U.S., production vehicles designed to operate on alcohol are all designed as FFVs, or vehicles that operate on methanol/gasoline blends in the range from $85 \%$ methanol $/ 15 \%$ gasoline to $100 \%$ gasoline. Recently some FFVs have been designed to run on ethanol rather than methanol.

Having chosen an FFV for the beginning platform, a particular manufacturer needed to be chosen. Because this work was funded by DOE, the vehicle had to be produced by a U.S.-based manufacturer. At the time the choice was made, GM had decided to stop producing FFVs, although there were many 3.1-liter Chevrolet Lumina vehicles in fleets. Chrysler was switching between vehicles and engines for its FFVs. Therefore, the Ford Taurus FFV with the 3.0-liter Vulcan engine was chosen as the starting platform. An advantage of this choice was that the vehicle had low emissions to start with, meeting transitional low-emission vehicle (TLEV) standards. A disadvantage was the relatively old engine design, a push-rod, two-valve per cylinder engine with a "bathtub" combustion chamber.

Because work was being conducted on the engine and the aftertreatment systems simultaneously, two 1993 Ford Taurus FFVs were obtained. The first was used in the standard production form but with various advanced aftertreatment systems. The second was used for engine development, and the engine was removed and placed in an engine test cell in a refrigerated chamber. Results from both these efforts shall be combined in one demonstrator vehicle.

\section{Accelerated Schedule}

At NREL's and DOE's request, SwRI submitted a proposal to accelerate the project from the originally proposed 42 months to 32 months. That proposal was approved after the end of Phase 2. That proposal included the development of a digital signal processor (DSP) based engine controller, the development and application of model-based controls with the help of consultant Robert Weeks, consulting by Mr. David Gardiner concerning low-temperature cold-start, and increased efforts in managing the overall project and incorporating technologies developed at NREL and other laboratories.

\section{Technical Papers}

Two technical papers were written and the accompanying presentations given concerning this project. A technical paper and presentation were prepared for the 1994 Annual Automotive Technology Development Contractors' Coordination Meeting in Detroit. A paper was also presented at the SAE Congress in February 1995. This second paper described estimates of fuel evaporation rates using the trajectory and evaporation of spray systems (TESS) code. The calculations included estimates for bench tests, where 
high-quality data for drop sizes and fuel vaporization rate were available for comparison with calculated results, and in-cylinder computations, where there is little knowledge about evaporation rates. The capability for in-cylinder calculations was developed on a previous NREL/DOE project, and the incylinder calculations were for the Ford 3.0-liter high-compression engine being developed for this project. 


\section{Table of Contents}

$\underline{\text { Page }}$

Task 1 Fuel Blending and Testing $\ldots \ldots \ldots \ldots \ldots \ldots \ldots \ldots \ldots \ldots \ldots \ldots \ldots$

Objective $\ldots \ldots \ldots \ldots \ldots \ldots \ldots \ldots \ldots \ldots \ldots \ldots \ldots \ldots \ldots \ldots \ldots \ldots \ldots \ldots \ldots \ldots$

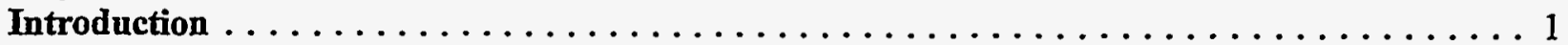

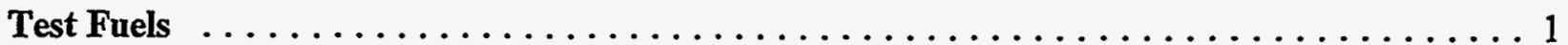

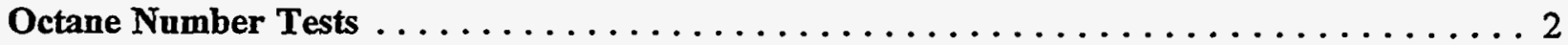

American Society for Testing \& Material Standards for Ethanol Fuel Blends . . . . . . . 2

Vapor Pressure Measurements and Correlations $\ldots \ldots \ldots \ldots \ldots \ldots \ldots \ldots \ldots \ldots \ldots$

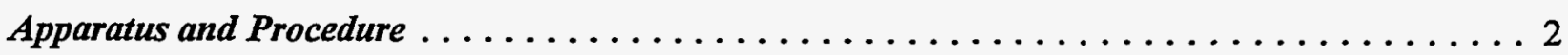

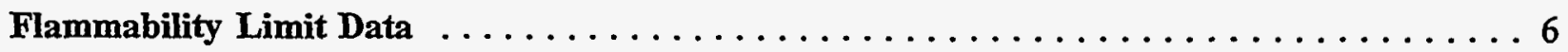

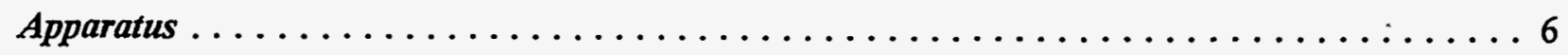

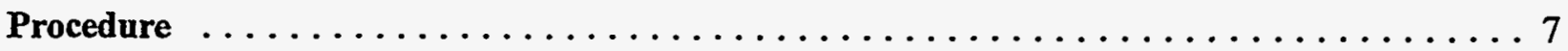

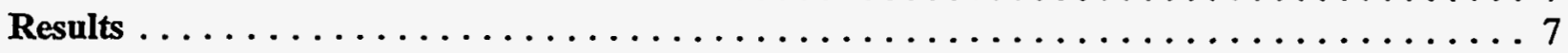

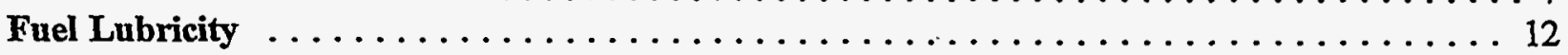

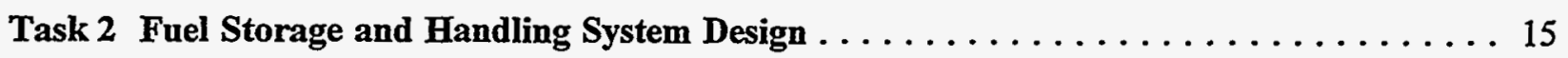

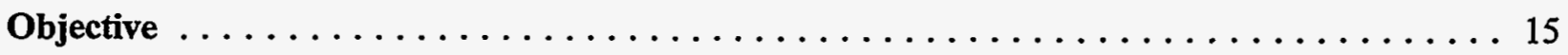

Discussion of Material Compatibility Issues $\ldots \ldots \ldots \ldots \ldots \ldots \ldots \ldots \ldots \ldots \ldots \ldots \ldots$

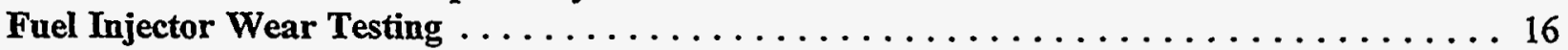

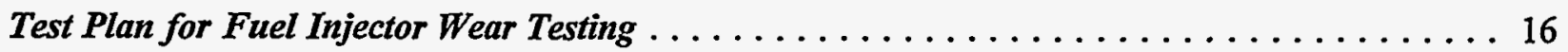

Alternative Fuels Refueling Conference and Trade Show $\ldots \ldots \ldots \ldots \ldots \ldots$

Task 3 Engine System Assembly and Testing $\ldots \ldots \ldots \ldots \ldots \ldots \ldots \ldots \ldots \ldots \ldots$

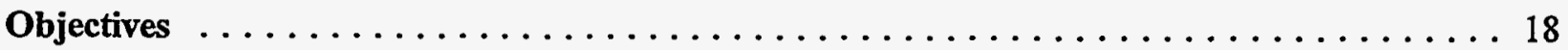

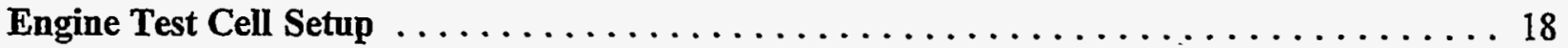

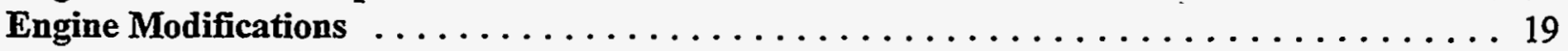

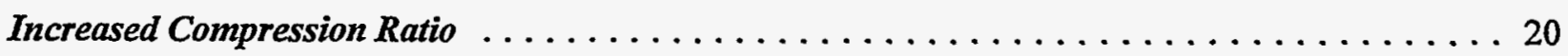

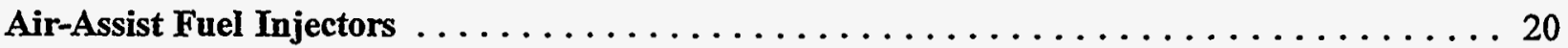

Rapid Prototyping Engine Control System (RPECS) Engine Controller . . . . . . . . . . 24

Task 4 Emissions Control System Development and Testing ............. 25

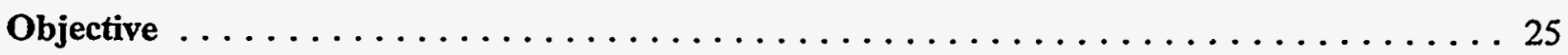

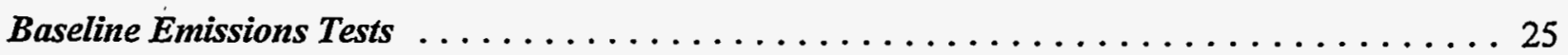




\section{Table of Contents (Cont'd)}

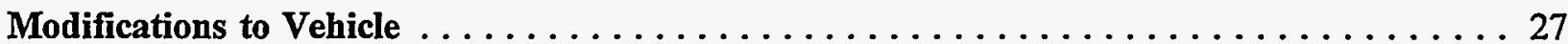

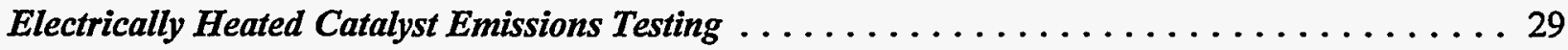

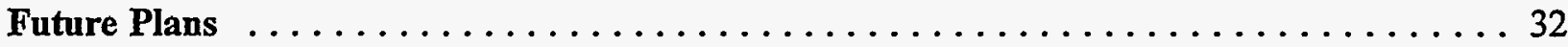

Task 5 Fuel/Engine/Vehicle System Integration $\ldots \ldots \ldots \ldots \ldots \ldots \ldots \ldots \ldots \ldots$

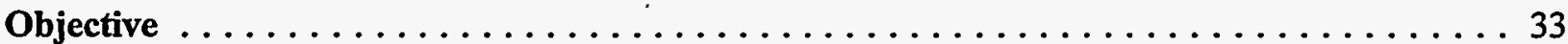

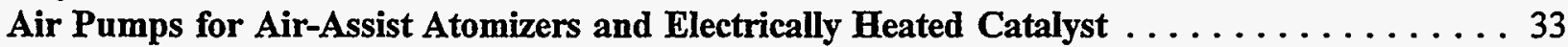

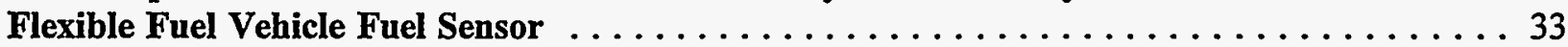

Task 6 Integrated Fuel/Engine System Optimization $\ldots \ldots \ldots \ldots \ldots \ldots \ldots$

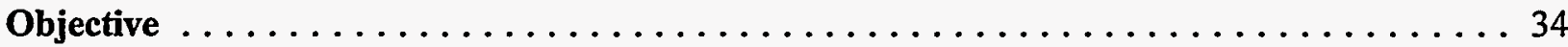

Rapid Prototyping Engine Control System Engine Controller Hardware . . . . . . . . . . 34

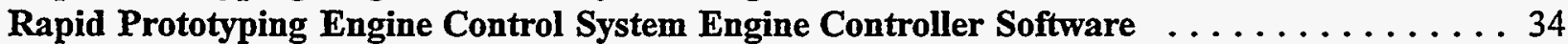

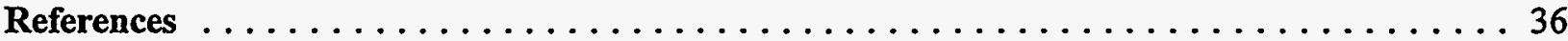

Appendices

A Standard Specification for Fuel Ethanol (Ed85-Ed75)

for Automotive Spark-Ignition Engines (Draft ASTM Standard)

B SAE J1832 - SAE Recommended Practice for Gasoline Fuel Injector 


\section{List of Figures}

Figure

Page

1-1 Effect of temperature on vapor pressure of ethanol/unleaded gasoline blends. . . . . 3

1-2 Effect of temperature on vapor pressure of E95 blends. $\ldots \ldots \ldots \ldots \ldots \ldots$

1-3 Effect of temperature on vapor pressure of $\mathbf{E 8 5}$ blends. $\ldots \ldots \ldots \ldots \ldots \ldots$

1-4 Flammability test apparatus. $\ldots \ldots \ldots \ldots \ldots \ldots \ldots \ldots \ldots \ldots \ldots \ldots$

1-5 Temperature limits of flammability of ethanol blends

containing $5 \%$ and $15 \%$ fuel additive. $\ldots \ldots \ldots \ldots \ldots \ldots \ldots \ldots$

3-1 Piston and combustion chamber for Ford Taurus 3.0 -liter V-6. . . . . . . . 22

3-2 Southwest Research Institute internal-mix air-assist injectors. . . . . . . . 23

3-3 Effect of atomizing air pressure on average drop as represented by Sauter Mean Diameter $\left(\mathrm{D}_{32}\right.$, standard Taurus 3.0-liter flexible fuel injector and fuel-air mixing cap with $1-\mathrm{mm}$ exit hole. $\ldots \ldots \ldots \ldots \ldots \ldots \ldots \ldots \ldots \ldots \ldots$

4-1 Schematic of standard original equipment manufacturer exhaust system and Southwest Research Institute experimental exhaust system $\ldots \ldots \ldots \ldots \ldots \ldots$

6-1 The PC-based controller for engine test cell. . . . . . . . . . . . . 35 


\section{List of Tables}

Table

$\underline{\text { Page }}$

1-1 Octane Measurements for E80 (Ed85) (80\% Ethanol, $20 \%$ Unleaded Gasoline).

1-2 Ethanol and Ethanol Blend Vapor Pressures as a Function of Temperature . . . . . . 4

1-3 Correlating Parameters for Vapor Pressure Expressions:

$\mathbf{L n}(\mathbf{P})=\mathbf{A}+\mathbf{B} / \mathbf{T}+\mathbf{C} / \mathbf{T}^{2}$, Units: $\mathbf{P}$ in $\mathbf{k P a}$, $\mathbf{T}$ in Degrees $\mathbf{K} . \ldots \ldots \ldots \ldots$

1-4 Ethanol/Ethanol Blends Flammability Test Results. $\ldots \ldots \ldots \ldots \ldots \ldots \ldots$

1-5 Comparison of Calculated with Measured Temperature Limits of Flammability. . . . 11

1-6 Fuel Lubricity Determined from Wear Tests with the Ball on Cylinder

Lubrication Evaluator. . . . . . . . . . . . . . . . . . . . . . . 13

1-7 Ball on Cylinder Lubrication Evaluator Tests on Alcohols and Oxygen. . . . . . . . 13

3-1 Ford 3.0-liter Flexible Fuel Vehicle - Cylinder Modifications. . . . . . . . . . 20

4-1 Baseline Federal Test Procedure Exhaust Emissions from Ford Flexible

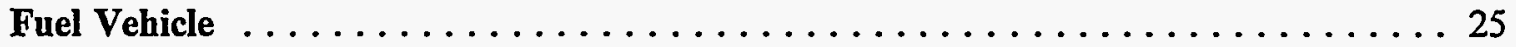

4-2 Weighted Baseline Federal Test Procedure Exhaust Emissions for Ford

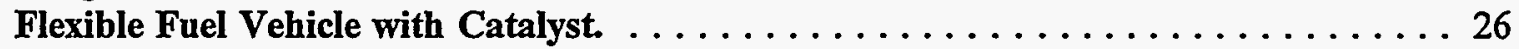

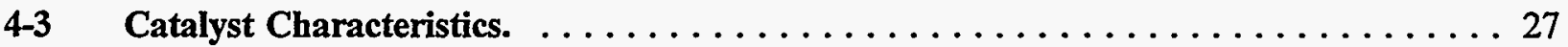

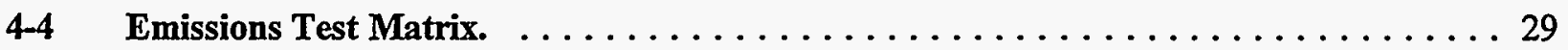

4-5 Federal Test Procedure Exhaust Emissions from Flexible Fuel Vehicle

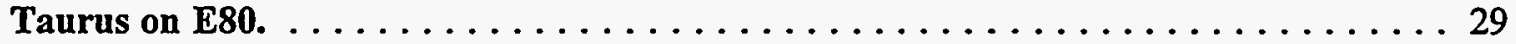

4-6 Federal Test Procedure Exhaust Emissions from Ford Flexible Fuel Vehicle. . . . . . 30

4-7 Weighted Federal Test Procedure Exhaust Emissions - Electrically Heated

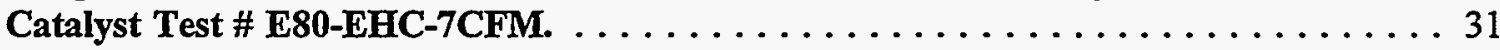




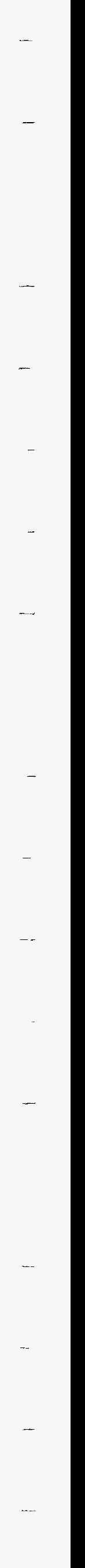




\section{Task 1 Fuel Blending and Testing}

\section{Objective}

The objective of Task 1 was to determine the effects of ethanol fuel-additives on fuel tank flammability, cold startability, corrosion, wear, and lubricity.

\section{Introduction}

Fuel tank flammability is a safety concern that has been sometimes overlooked because very few (if any) fire-related accidents in automobiles have been attributed to explosions within the fuel tank. Most accidents involving fire are caused by fuel tank rupture. Spilled gasoline is the worst of fire hazards because its vapors quickly envelop the vehicle causing a tumultuous deflagration. Other fire hazards involve fuel leaks in the engine compartment where the hot exhaust manifold and corona discharge around ignition wires are potential ignition sources.

At temperatures above $-10^{\circ} \mathrm{C}\left(14^{\circ} \mathrm{F}\right)$, the concentration of gasoline fumes in the vapor space of an automotive fuel tank is above the rich flammability limit (Goodger 1980). When the fuel temperature is below $\approx-40^{\circ} \mathrm{C}\left(\approx-40^{\circ} \mathrm{F}\right)$ the vapor concentration falls below the lean flammability limit. Between $-10^{\circ} \mathrm{C}$ $\left(14^{\circ} \mathrm{F}\right)$ and $-40^{\circ} \mathrm{C}\left(-40^{\circ} \mathrm{F}\right)$, the vapors are flammable and could be ignited if subjected to a sufficiently strong ignition source. Temperatures that define the flammable range of the fuel vapor are termed the upper and lower temperature limits of flammability. Temperature limits of flammability are affected by Reid vapor pressure (RVP) and fuel composition.

A primary objective in Task 1 was to develop correlations of vapor pressure with temperature that could be used to predict temperature limits of flammability and cold startability. Cold start depends on the rate at which fuel can evaporate at low temperatures. Vapor phase equilibrium plays an important role in the evaporation of fuel droplets. The results of Task 1 will give important information for evaporation models used to predict cold start in ethanol fueled engines.

Combustion associated corrosion and wear were discussed in Phase 1 (Bourn et al. 1994). Fuel lubricity, which is important to fuel pump and fuel injector wear, is a topic of the present report. It is measured in terms of a wear pattern produced as the result of rubbing two metal surfaces together in the presence of the fuel. Experience has shown that oxygenated fuels have lubricating properties similar to gasolines. However, alcohols absorb water, which degrades fuel lubricity.

In Task 1, measurements of vapor pressure, temperature limits of flammability, and fuel lubricity were made on E100 (neat ethanol), Ed85 (85\% denatured ethanol, 15\% gasoline), and various blends of neat ethanol and blending stocks. The effects of water absorption and dissolved oxygen on fuel lubricity are addressed. 


\section{Test Fuels}

The fuels included E100, gasoline, a baseline fuel Ed85, six blends of neat ethanol that contained $15 \%$ unleaded gasoline, butane, pentane, isopentane, $\mathrm{C}_{5} / \mathrm{C}_{6}$ isomerate, and diethyl ether. In addition, six similar blends that contained $5 \%$ of the same additives were made. The baseline fuel Ed85 is also referred to as E80 because the denatured ethanol is often 5\% gasoline. Hence, the terms Ed85 and E80 are interchangeable in this report.

\section{Octane Number Tests}

An outside lab determined octane numbers on the Ed85 (or E80) fuel with the results shown in Table 1-1. These results suggest a blending octane number $(R+M) / 2$ for the neat ethanol was 105.7 . That is, the gasoline lowers the $(\mathrm{R}+\mathrm{M}) / 2$ octane number of neat ethanol from about 105.7 to 102.1 , which is significantly higher than the highest octane motor gasolines. For an Ed85 dedicated vehicle as opposed to the flexible fuel type, the higher octane number would permit a higher compression ratio and improved cycle efficiency.

Table 1-1. Octane Measurements for E80 (Ed85) (80\% Ethanol, 20\% Unleaded Gasoline).

\begin{tabular}{cc}
\hline Method & Octane Number \\
\hline Research (R) & 104.8 \\
Motor (M) & 99.3 \\
$(\mathrm{R}+\mathrm{M}) / 2$ & 102.1 \\
\hline
\end{tabular}

Because water affects the octane number and the miscibility of ethanol in gasoline, the fuel blends were prepared with anhydrous ethanol. Desiccant breathers were installed on all opened fuel drums to prevent water from contaminating the fuel. The air breather tubes were closed when the fuels were not in use.

\section{American Society for Testing Materials Standards for Ethanol Fuel Blends}

American Society for Testing Material (ASTM) Committee D-2 on Petroleum Products and Lubricants is currently working on a new Standard Specification for Fuel Ethanol (Ed85-Ed70) for Automotive SparkIgnition Engines. This specification defines different volatility classes for ethanol fuels throughout the U.S. based on geographic location and month of the year. The approach recognizes that the RVP of gasoline used in blending E80 should be increased to prevent problems with cold starting and driveability in cold weather. Southwest Research Institute is not directly involved in the ASTM effort, but the results of the study are important in the present project to define the fuel characteristics required for different cold-start conditions. This project may result in hardware that might reduce the fuel volatility requirement, but much work remains before that can be fully assessed. A draft copy of the proposed standard is attached as Appendix A. 


\section{Vapor Pressure Measurements and Correlations}

\section{Apparatus and Procedure}

Vapor pressures were measured with a Grabner model CCA-VPS and a Grabner model CCA-VP equipped with Peltier cooler. A separate fluid cooling apparatus was used to help the Peltier cooler reach temperatures below $-1^{\circ} \mathrm{C}\left(30^{\circ} \mathrm{F}\right)$. The instruments were calibrated with 2,2-dimethyl butane and $\mathrm{n}$ pentane standards. Fresh blends of $5 \%$ and $15 \%$ by volume of $n$-butane, n-pentane, i-pentane, isomerate, diethyl ether, and UNLG with ethanol were prepared. Their vapor pressures were determined at $-14.4^{\circ} \mathrm{C}$ $\left(6^{\circ} \mathrm{F}\right),-1.1^{\circ} \mathrm{C}\left(30^{\circ} \mathrm{F}\right), 21.1^{\circ} \mathrm{C}\left(70^{\circ} \mathrm{F}\right), 37.7^{\circ} \mathrm{C}\left(100^{\circ} \mathrm{F}\right)$, and $54.4^{\circ} \mathrm{C}\left(130^{\circ} \mathrm{F}\right)$. The results of these vapor pressure measurements are shown in Table 1-2.

Figures 1-1 through 1-3 show Clapeyron-Clausius plots of the vapor pressure data for the ethanol blends in Table 1-2. Significant curvature is observed in most of the plots. For each fuel, the data were correlated according to the expression,

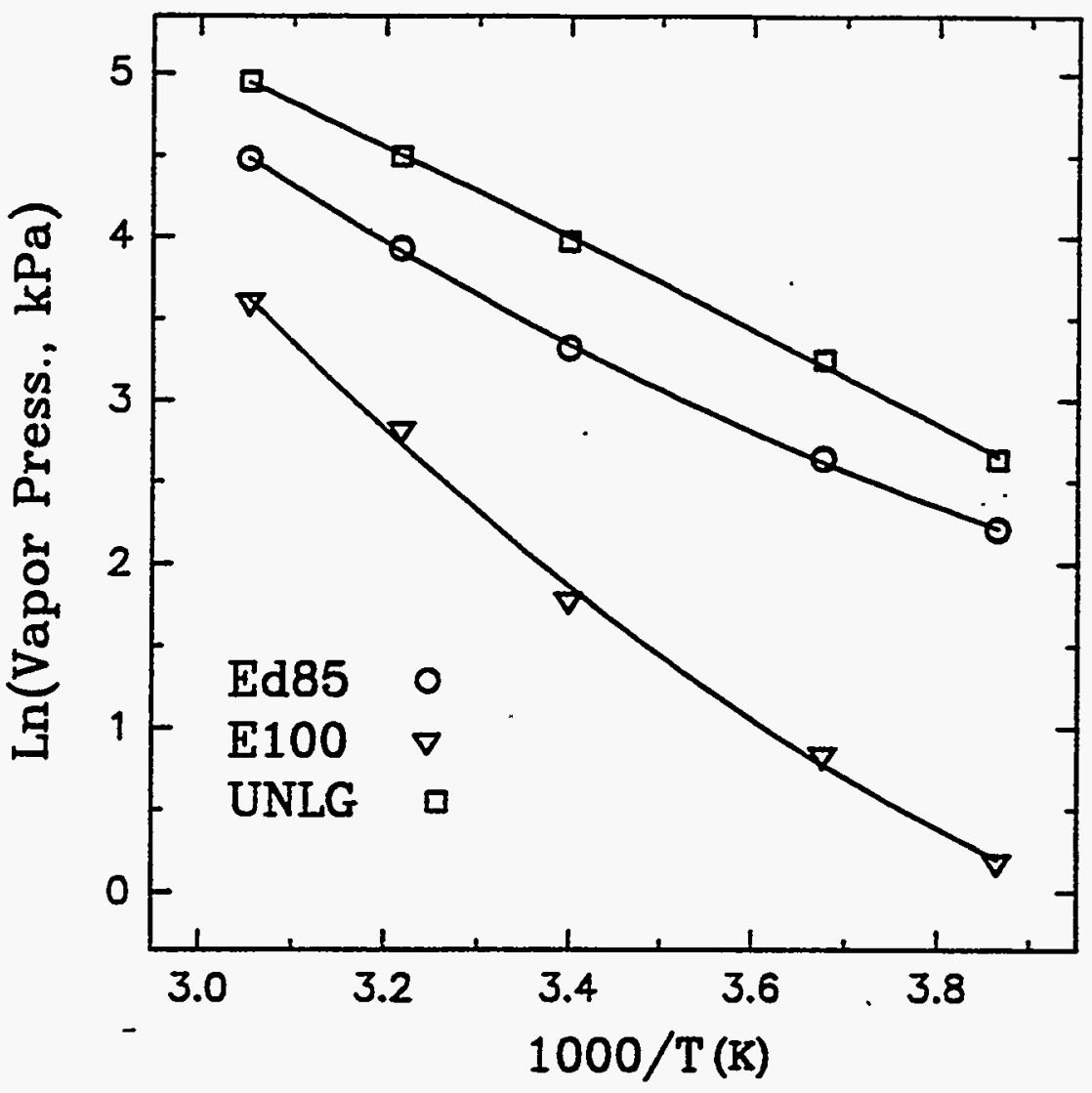

Figure 1-1. Effect of temperature on vapor pressure of ethanol/unleaded gasoline blends. 


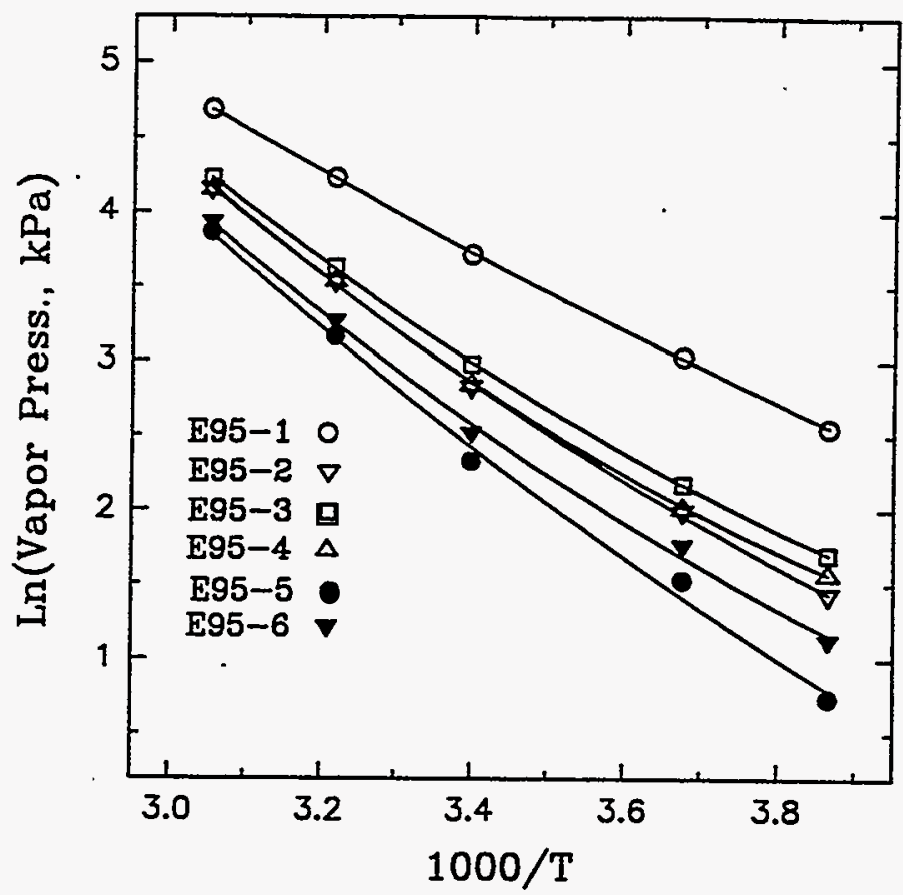

Figure 1-2. Effect of temperature on vapor pressure of E95 blends.

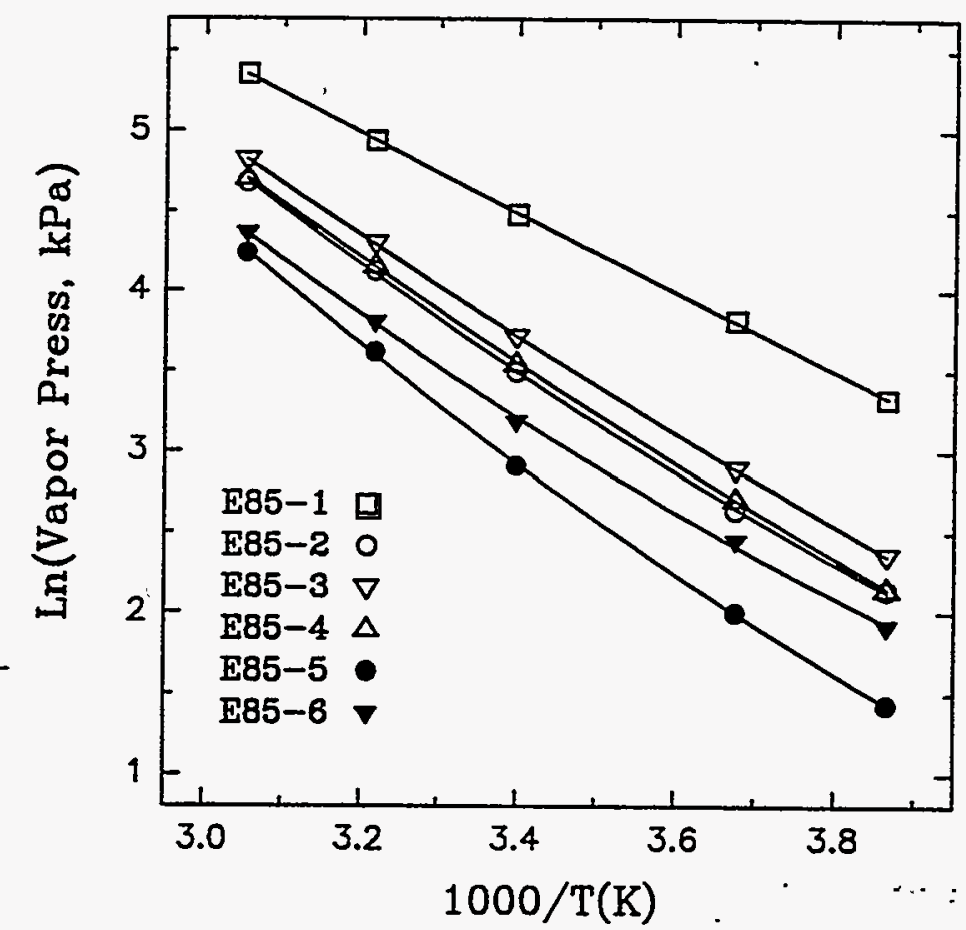

Figure 1-3. Effect of temperature on vapor pressure of E85 blends. 
Table 1-2. Ethanol and Ethanol Blend Vapor Pressures as a Function of Temperature.

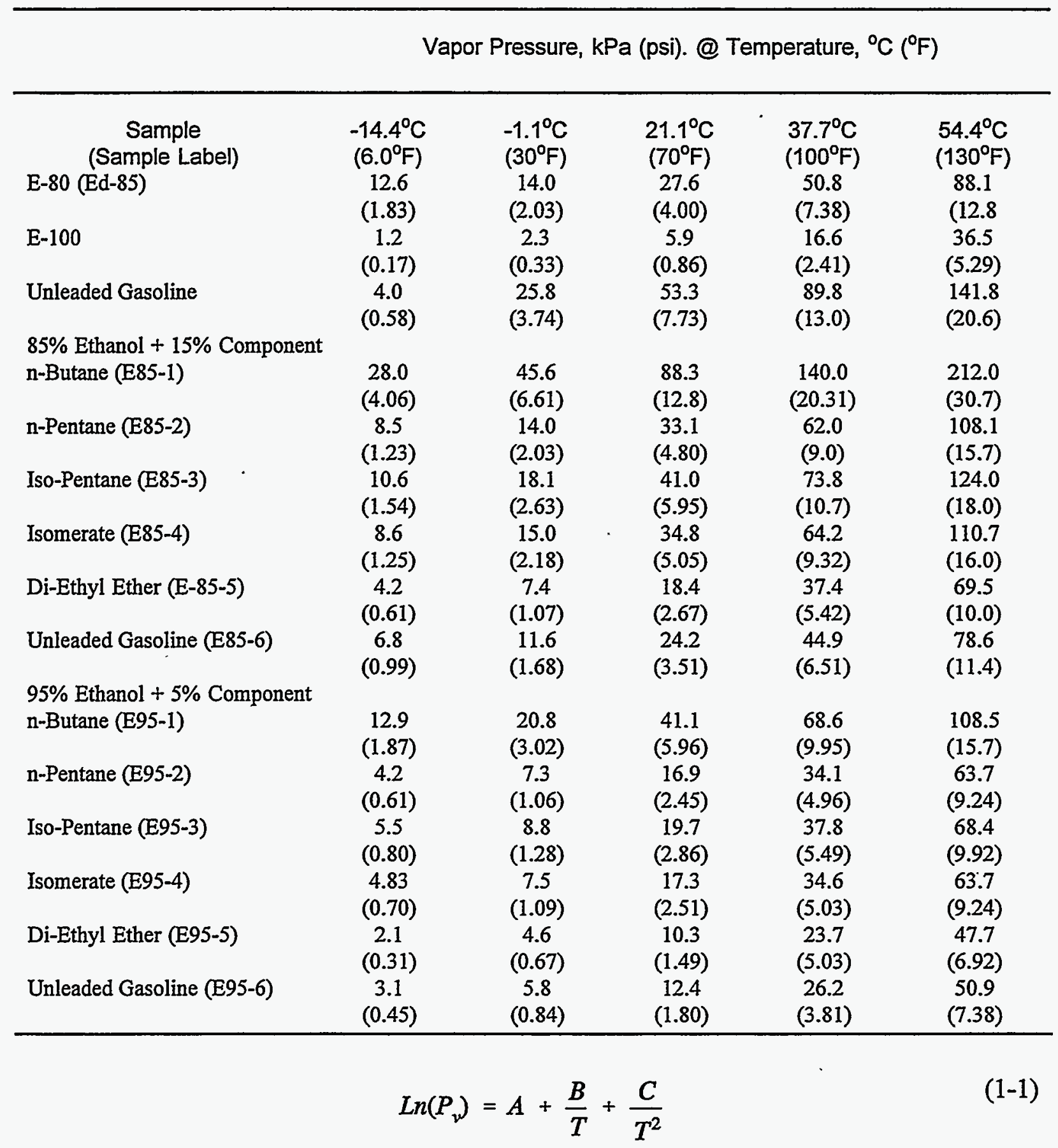

where $\mathrm{P}_{\mathrm{v}}$ is the vapor pressure, $\mathrm{T}$ is the absolute temperature, and $\mathrm{A}, \mathrm{B}$, and $\mathrm{C}$ are fuel dependent constants. Equation 1-1 is an extension of the Clapeyron-Clausius equation where the term, $C / T^{2}$, was added to account for the nonlinearity of the curves shown in Figures 1-1 through 1-3. Table 1-3 lists the parameters $\mathrm{A}, \mathrm{B}$, and $\mathrm{C}$ for the various fuels that have been examined. 
Table 1-3. Correlating Parameters for Vapor Pressure Expressions: $\operatorname{Ln}(P)=A+B / T+C / T^{2}$, Units: $P$ in $\mathrm{kPa}, \mathrm{T}$ in Degrees $\mathrm{K}$.

\begin{tabular}{lcccc}
\hline \multicolumn{1}{c}{ Fuel Description } & Code Name & A & B & C \\
\hline Unleaded Gasoline & UNLG & 11.34 & $-1,520.0$ & $-1.878 \times 10^{5}$ \\
Neat Ethanol & E100 & 38.36 & $-17,040.0$ & $1.855 \times 10^{6}$ \\
Ethanol - 20\% UNLG & E80 & 37.98 & $-17,660.0$ & $2.193 \times 10^{6}$ \\
Ethanol - 15\% n-Butane & E85-1 & 13.29 & $-2,692.0$ & $3.050 \times 10^{4}$ \\
Ethanol - 15\% n-Pentane & E85-2 & 21.81 & $-7,541.0$ & $6.340 \times 10^{5}$ \\
Ethanol - 15\% iso-Pentane & E85-3 & 18.06 & $-5,365.0$ & $3.368 \times 10^{5}$ \\
Ethanol - 15\% C $/ C_{6}$ Isomerate & E85-4 & 18.87 & $-5,817.0$ & $3.856 \times 10^{5}$ \\
Ethanol - 15\% Diethyl Ether & E85-5 & 23.88 & $-8,768.0$ & $7.661 \times 10^{5}$ \\
Ethanol - 15\% UNLG & E85-6 & 21.61 & $-7,751.0$ & $6.879 \times 10^{5}$ \\
Ethanol - 5\% n-Butane & E95-1 & 16.49 & $-4,853.0$ & $3.236 \times 10^{5}$ \\
Ethanol - 5\% n-Pentane & E95-2 & 25.21 & $-9,701.0$ & $9.190 \times 10^{5}$ \\
Ethanol - 5\% iso-Pentane & E95-3 & 25.68 & $-10,110.0$ & $1.012 \times 10^{6}$ \\
Ethanol- 5\% C /C 6 Isomerate & E95-4 & 28.55 & $-11,760.0$ & $1.237 \times 10^{6}$ \\
Ethanol - 5\% Diethyl Ether & E95-5 & 24.45 & $-9,099.0$ & $7.708 \times 10^{5}$ \\
Ethanol - 5\% UNLG & E95-6 & 26.57 & $-10,600.0$ & $1.041 \times 10^{6}$ \\
\hline
\end{tabular}

Curvature is caused by changes in the heat of vaporization with temperature and the effect of temperature on the solubility of the additive in ethanol. At lower temperatures, the nonpolar hydrocarbon additives become less miscible in ethanol so their vapor pressure dependence on concentration becomes more nonideal. Nonideal solutions have higher vapor pressures because the components act more independently to produce the observed vapor pressure. All ethanol-hydrocarbon solutions are nonideal, so lowering the temperature tends enhance that effect (make the solutions more nonideal). In contrast, the E95-5 and E855 blends of ethanol and diethyl ether have much lower vapor pressures than the ethanol-hydrocarbon blends because diethyl ether forms a nearly ideal solution with ethanol.

However, a more detailed analysis of the data involving parameters such as equivalence ratio, fuel-air ratio, and measured flammability limits was desired. The vapor pressure temperature correlations represented by Equation 1-1 are used with literature data on flammability limits to predict the upper temperature limits of flammability given in the next section. 


\section{Flammability Limit Data}

\section{Apparatus}

The apparatus used in this study was similar to those used by Fanick et al. (1990) and Lawson et al. (1987) to measure flammability limits of fuel vapors. The combustion vessel shown in Figure 1-4 was a $500-\mathrm{mL}$ three-neck round-bottom pyrex flask. The flask dimensions were sufficient to preclude wallquenching effects on the flammability limits (Zabertakis 1952; Coward and Jones 1952). The electrodes for ignition and the thermocouples for measuring fuel temperature were mourited in rubber stoppers that were placed in ports of the round bottom flask. The igniter electrodes consisted of two 10$\mathrm{cm}$ lengths of 14-gauge copper wire mounted in parallel $12.7-\mathrm{mm}$ apart in the stopper. The copper electrodes were sharpened to a point and bent at the ends to form a $2.5-\mathrm{mm}$ spark-gap at the center of the flask. The electrodes were insulated with a polyethylene sheath up to where they were bent to form the spark-gap. An automotive spark coil capable of producing a continuous $400-\mathrm{Hz}$ oscillating arc discharge was used to ignite the fuel vapors.

In fuel tanks, one ignition source of concern is a spark created by a triboelectric source charge accumulation in the fuel. Another source is a person charged with static electricity standing next to an open fuel tank. van Dolah et al. (1963) gave an interesting example; if an average-sized man with a capacitance of $300 \mathrm{pF}$ builds up a charge of 10,000 volts, a discharge with an energy of $15 \mathrm{~mJ}$ could be initiated. From this standpoint, the automotive spark coil igniter, which produced a highly visible arc between the electrodes, was assumed to be an overwhelming ignition source.

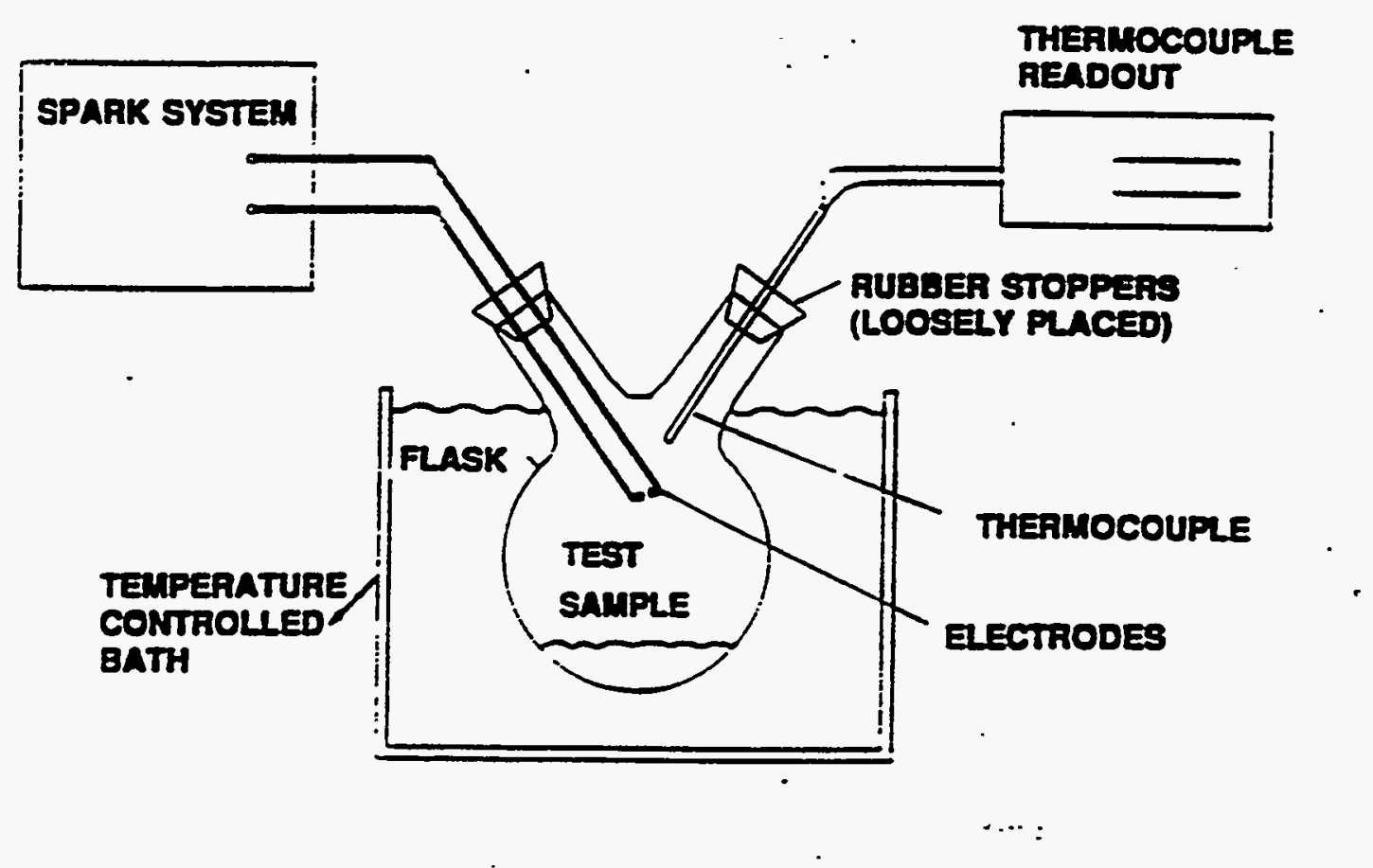

Figure 1-4. Flammability test apparatus. 


\section{Procedure}

The combustion vessel was filled with $25 \mathrm{~mL}$ of test fuel. It was agitated to wet the walls of the flask so the fuel would evaporate and mix with the air. The flask was immersed in a constant temperature isopropanol/water bath controlled to within $0.5^{\circ} \mathrm{C}$. It required about 30 minutes for the liquid fuel and bath temperatures to equilibrate. An attempt was made to ignite the fuel-air mixture about 20 minutes after the liquid fuel and bath temperatures reached equilibrium. The temperature limits of flammability were determined by trial and error.

At the start of testing, a presumed bath temperature was chosen. If ignition occurred at the chosen temperature, it would be characterized as weak, medium, or strong, depending on the aural (visual) intensity of the explosion. If the explosion was weak, the conditions were very close to the temperature limit of flammability. Therefore, in the next test the bath temperature would be raised just a few degrees. If no ignition occurred, the temperature limit was within a few degrees of the bath temperature in the last test. Once the temperature limit of flammability was bracketed to within a few degrees, tests were performed in $1^{\circ} \mathrm{C}$ increments to achieve accuracy to within $1^{\circ} \mathrm{C}$.

\section{Results}

Rich and lean flammability limits were measured, and are presented in Table 1-4. Figure 1-5 shows the flammability results from Table 1-4 plotted versus the RVP, which is the vapor pressure measured at $37.7^{\circ} \mathrm{C}\left(100^{\circ} \mathrm{F}\right)$, from Table $1-2$. The flammability limits correlate with the RVP, except those data that are tagged with labels. The labels in Figure 1-5 correspond with those defined in Table 1-2. The flammability limits may be predicted from the Reid vapor pressures except for the mixtures with n-butane, diethyl ether, and neat ethanol.

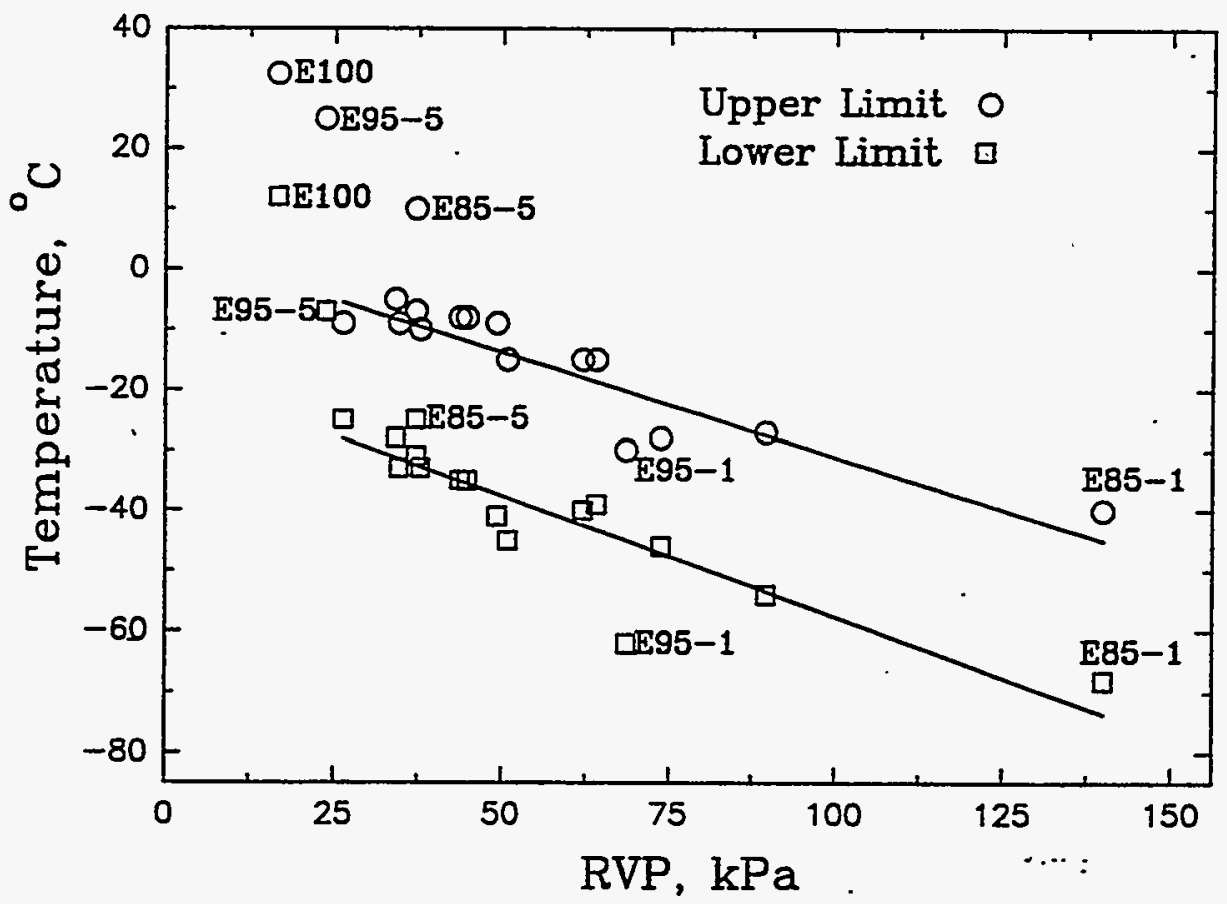

Figure 1-5. Temperature limits of flammability of ethanol blends containing $5 \%$ and $15 \%$ fuel additive. 
The relationship between fuel vapor pressure and flammability limits was investigated further to determine how the flammability limits may be accurately predicted from the vapor pressures. This is important in estimating both engine cold startability and fuel tank flammability. N-butane shows a different flammability versus vapor pressure than the other mixtures because it forms a less ideal solution with ethanol; i.e., it does not follow Raoult's law for vapor pressures of mixtures. In contrast, the di-ethyl ether and ethanol form a relatively ideal mixture, which explains why ether blends do not show the same correlation of flammability limits versus RVP as the other blends. For the ethanol blends, much of the flammability is due to the hydrocarbon fractions.

For neat ethanol, only the ethanol vapors are available for combustion. Because of the different stoichiometry for ethanol combustion, more fuel vapor is required, which increases the temperature limit for flammable mixtures above that of the ethanol blends. The E100 and blends that contain n-butane and diethyl ether presumably deviate from the general dependence of temperature limit versus RVP because of differences in stoichiometry. As an example, the air-fuel ratio for stoichiometric combustion of gasoline is about 14.6 , but ethanol is 9.01 . The lean flammability limits for both materials are roughly at an equivalence ratio of 0.5 , but this is an air-fuel ratio of about 29 for gasoline/air and 18 for ethanol/air mixtures.

Table 1-4. Ethanol/Ethanol Blends Flammability Test Results.

\begin{tabular}{ccc}
\hline Sample & \multicolumn{2}{c}{ Flammability Limits } \\
E80 & Upper ${ }^{\circ} \mathrm{C}$ (Rich) & Lower ${ }^{\circ} \mathrm{C}$ (Lean) \\
E100 & -15 & -45 \\
Unleaded Gasoline & 33 & 12 \\
$85 \%$ ETOH + 15\% n-Butane & -27 & -54 \\
$85 \%$ ETOH + 15\% n-Pentane & -40 & -69 \\
$85 \%$ ETOH + 15\% Iso-Pentane & -15 & -40 \\
$85 \%$ ETOH +15\% Isomerate & -20 & -46 \\
$85 \%$ ETOH + 15\% Di-Ethyl Ether & -15 & -39 \\
$85 \%$ ETOH + 15\% Unleaded Gasoline & -10 & -25 \\
$95 \%$ ETOH + 5\% n-Butane & -8 & -35 \\
$95 \%$ ETOH + 5\% n-Pentane & -30 & -62 \\
$95 \%$ ETOH + 5\% Iso-Pentane & -5 & -28 \\
$95 \%$ ETOH +5\% Isomerate & -10 & -33 \\
$95 \%$ ETOH + 5\% Di-Ethyl Ether & -9 & -33 \\
$95 \%$ ETOH + 5\% Unleaded Gasoline & 25 & -7 \\
\hline
\end{tabular}


To account for variations in fuel composition, a simple computer model was written to use the vapor pressure measurements of the blends to estimate the molar ratios of ethanol and the additive, and then compute the equivalence ratio for the blends, accounting for the different fuel-air ratios required for the components. A computer code was written to calculate the upper and lower temperature limits of flammability from the vapor pressure and flammability limit data.

The calculations were performed by assuming that the partial pressure of ethanol, $\mathrm{P}_{\mathrm{E}}$, in the fuel blend is equal to,

$$
P_{E}=X_{E} P_{N}
$$

where $X_{E}$ is the mole fraction of ethanol in the liquid phase, and $P_{N}$ is the vapor pressure of neat ethanol. The partial pressure, $\mathrm{P}_{\mathrm{A}}$, of the fuel additive, e.g., butane, pentane, etc., was determined as,

$$
P_{A}=P_{F B}-P_{E}
$$

where $\mathrm{P}_{\mathrm{FB}}$ is the vapor pressure of the fuel blend. The mole $\%$ of ethanol vapor, $\mathrm{C}_{\mathrm{E}}$, and additive vapor, $\mathrm{C}_{\mathrm{A}}$, were expressed as,

$$
C_{E}=100 \frac{P_{E}}{P_{t}}
$$

and,

$$
C_{A}=100 \frac{P_{A}}{P_{t}}
$$

where $P_{t}$ is the total pressure, e.g., the atmospheric pressure.

Flammability limit data for neat ethanol and the pure components, n-butane, n-pentane, i-pentane, and diethyl ether were obtained from the literature (Hodgman 1957). The flammability limits of the vapors from unleaded gasoline were weighted about $70 \%$ butane and $30 \%$ pentane. The vapors from the isomerate were weighted about $70 \%$ pentane and $30 \%$ hexane. More accurate vapor compositions could have been determined by speciating the vapor space, but they were not.

Various approaches were used in combining the flammability limits of the components to arrive at the flammability limit of the ethanol-additive mixture. The following method of combining flammability limits was used. First, Equation 1-6 below was used to calculate the stoichiometric air-fuel ratios, $\mathrm{AFR}_{\mathrm{ST}}$, of the components.

$$
A F R_{S T}=4.76(x+y / 4-z / 2)
$$


The variables $\mathrm{x}, \mathrm{y}$, and $\mathrm{z}$ are the numbers of carbon, hydrogen and oxygen atoms respectively. The factors $\mathrm{F}_{\mathrm{A}}$ and $\mathrm{F}_{\mathrm{E}}$ were calculated via,

$$
F_{E}=\frac{P_{E} A F R(E)_{S T}}{P_{E} A F R(E)_{S T}+P_{A} A F R(A)_{S T}}
$$

and,

$$
F_{A}=1-F_{E}
$$

where AFR(E) $)_{S T}$ and AFR(A) $)_{S T}$ are the stoichiometric air-fuel ratios for ethanol and the additive. The flammability limit of the mixture, $\mathrm{L}_{\mathrm{M}}$, is then expressed as,

$$
L_{M}=F_{E} L_{E}+F_{A} L_{A}
$$

where $\mathrm{L}_{\mathrm{E}}$ and $\mathrm{L}_{\mathrm{A}}$ are the respective flammability limits of ethanol and the additive.

Finally, the temperature limit of flammability is determined when the Equation 1-10 below is satisfied.

$$
L_{M}=C_{E}+C_{A}
$$

Table 1-5 shows the upper temperature limits of flammability that were calculated by an iterative technique involving Equations 1-1 through 1-10. The calculations were performed by making incremental changes in temperature until the temperature satisfied condition of Equation 1-10. 
Table 1-5. Comparison of Calculated with Measured Temperature Limits of Flammability.

\begin{tabular}{ccccc}
\hline Fuel Blend & $\begin{array}{c}\text { Upper Temperature Limits } \\
\text { of Flammability }\end{array}$ & \multicolumn{2}{c}{$\begin{array}{c}\text { Lower Temperature } \\
\text { Limits of Flammability } \\
\left({ }^{\circ} \mathrm{C}\right)\end{array}$} & \multicolumn{2}{c}{$\left.{ }^{\circ}\right)$} \\
& Meas. & Calc. & Meas. & Calc. \\
\hline E100 & 33 & 36.5 & 12 & 13.5 \\
ULG & -27 & -26 & -54 & -53 \\
EtOH + 15\% n-Butane & -40 & -43.5 & -69 & -70 \\
EtOH + 15\% n-Pentane & -15 & -16 & -40 & -56 \\
EtOH + 15\% Iso-Pentane & -20 & -20 & -46 & -56 \\
EtOH + 15\% Isomerate & -15 & -17 & -39 & -51 \\
EtOH + 15\% Diethyl Ether & 10 & 12 & -25 & -29 \\
EtOH + 15\% ULG & -8 & -8 & -35 & -49 \\
EtOH + 5\% n-Butane & -30 & -26 & -62 & -62 \\
EtOH + 5\% n-Pentane & -5 & 4 & -28 & -37 \\
EtOH + 5\% Iso-Pentane & -10 & -2 & -33 & -59 \\
EtOH + 5\% Isomerate & -9 & 2 & -33 & -106 \\
EtOH + 5\% Diethyl Ether & 25 & 25 & -7 & -10 \\
EtOH + 5\% ULG & -9 & 15 & -25 & -23 \\
EtOH + 20\% ULG & -15 & -17 & -45 & Error \\
\hline
\end{tabular}

* An error occurred in the iteration scheme for this fuel blend. This will be investigated further.

The results of the calculations were strongly dependent on the literature values of the flammability limits. For example, the flammability limits of ethanol given by Hodgman (1957) are 3.28 and 18.95 mole \% in air. When these values are used, the calculated lower and upper limits of flammability are $6^{\circ} \mathrm{C}$ and $41^{\circ} \mathrm{C}$ respectively. The calculated limits for neat ethanol in Table $1-5$ are based on lower and upper flammability limits of 4.4 and 14.3 mole \% respectively measured in a combustion bomb (Naegeli and Weatherford 1989).

A similar problem arises in computing the temperature limits of the ethanol/diethyl ether blends. Hodgman (1957) gives flammability limits of 1.85 and 36.5 mole \% in air for diethyl ether. The lower limit of 1.85 seems reasonable, but the measured upper temperature limits indicate that the upper flammability limit of diethyl ether is much lower than the literature value. Rich limits in the literature are often too high because they include cool flame reactions that give rise to chemiluminescence when there is no heat release or pressure rise accompanying the ignition process. The calculated values in Table 1-4 for the ethanol $/ 15 \%$ diethyl ether and ethanol/5\% diethyl ether blends were determined assuming that the upper flammability limit of diethyl ether is $12.5 \mathrm{~mole} \%$ in air. This is substantially lower than the literature value of 36.5 mole \%. Hence, from the standpoint of fuel tank flammability, we recommend that the flammability limits of diethyl ether and probably several other oxygenates should be reexamined. 
There was good agreement between measured and calculated upper and lower temperature limits of UNLG, E95, ethanol/15\% n-butane and ethanol/5\% n-butane blends. The agreement was good between measured and calculated upper limits, but poor between the lower limits of E85, and the blends of ethanol with $15 \% \mathrm{n}$-pentane, iso-pentane, and isomerate. The agreement was poor in upper and lower temperature limits of the ethanol blends containing $5 \%$ n-pentane, iso-pentane and isomerate. For the upper temperature limit, the problem seems not to be in the flammability limits of the additives, n-pentane, isopentane and isomerate, because the agreement was good in the $15 \%$ blends. However, the calculated lower temperature limits were well below the measured limits for both the $5 \%$ and $15 \%$ blends of ethanol that contained n-pentane, iso-pentane and isomerate. Increasing the lower flammability limits of npentane, iso-pentane, and isomerate by $30 \%$ made an improvement of only a few degrees in the calculated lower temperature limits. Because the literature values of the lower flammability limits are relatively accurate, the problem seems to be related to the accuracy of the vapor pressure expressions (see Equation 1-1).

Because of the curvature in the Clapeyron-Clausius plots of vapor pressure versus temperature, there is some question of the accuracy of the low temperature data. If there are inaccuracies in the database, extrapolations of vapor pressures to temperature beyond the range of the database could yield erroneous vapor pressure values. To resolve the problem, we recommend that the vapor pressures be rerun on freshly blended mixtures of E 80 and all the ethanol blends.

\section{Fuel Lubricity}

Fuel lubricity was measured with a Ball on Cylinder Lubrication Evaluator (BOCLE). In the BOCLE test, a steel ball locked in a fixed position rides on a rotating steel cylinder that is immersed in the test fluid. The contact frictional load between the ball and cylinder is controlled by a weight applied to a lever that forces the ball against the cylinder. The wear rates are measured in terms of the diameter of the wear scar on the steel ball. The wear scar is elliptical so its diameter is determined as the average of its width and length. Fuel lubricity is inversely proportional to the wear scar diameter.

In the standard BOCLE procedure, the test fluid is purged with room temperature air at a relative humidity of $10 \%$. Purging with air is applicable to lubricating oils and middle distillate fuels, but is seldom used with volatile fuels such as gasoline, ethanol, and ethers. It causes the fuel to evaporate and cool, and in some instances, fuels such as alcohols extract a large amount of water from the air. Because water has a significant effect on wear in the BOCLE test, there was no air purging of the ethanol and gasoline blends examined in the present study.

The results shown in Table 1-6 are interesting in that the wear scar diameter for ethanol is less than that for UNLG gasoline. Intuitively, it would seem that gasoline, which contains relatively high molecular weight hydrocarbons, would be a better lubricant than ethanol. There are various theories why ethanol is a better lubricant. One explanation is that ethanol's relatively high polarity causes it to adhere to the metal surface and act as a protective cushion. 
Table 1-6. Fuel Lubricity Determined from Wear Tests with the Ball on Cylinder Lubrication Evaluator.

\begin{tabular}{cc}
\hline Fuel Blend & Wear Scar Diameter, $\mathrm{mm}$ \\
\hline UNLG & 0.60 \\
Ethanol + 20\% UNLG & 0.59 \\
Ethanol + 15\% UNLG & 0.53 \\
Ethanol + 5\% UNLG & 0.52 \\
Neat Ethanol & 0.50 \\
Neat Methanol & 0.44 \\
\hline
\end{tabular}

An alternative theory assumes that ethanol has a higher resistance to oxidation than the hydrocarbons in gasoline. Tribologists conclude that very high lubricant temperatures are produced in the wear zone when aspirates on the metal surfaces make contact. The fuels almost always contain some dissolved oxygen, so the high temperatures cause the fuel to autoxidize. Corrosive substances such as peroxides and carboxylic acids may be among the oxidation products.

Wear rates usually decrease dramatically when dissolved oxygen is removed from the test fluid. If the test fluid is thoroughly purged with nitrogen to remove the dissolved oxygen before the test, and also purged with nitrogen throughout the test, the wear scar is greatly reduced.

Table 1-7 shows the results of recent experiments performed to determine the effect of removing oxygen on the lubricity of alcohols. The nitrogen and air used in the tests were preconditioned with $10 \%$ relative humidity at room temperature. The alcohols were absolute water free at the start of the test, but no doubt absorbed a significant amount of water during the test. Methanol and ethanol literally extract moisture from the air, the effect is much less with propanol, and relatively weak with butanol. The experiments "with air" and "with nitrogen" were performed in the same way so the effect of humidity on both tests was the same.

Table 1-7. Ball On Cylinder Lubrication Evaluator Tests on Alcohols with and without Oxygen.

\begin{tabular}{ccc}
\hline Alcohol Fuel & Type of Aeration & \\
\hline & With Air & With Nitrogen \\
Methanol & 0.53 & 0.51 \\
Ethanol & 0.83 & 0.47 \\
Propanol & 0.72 & 0.56 \\
Butanol & 0.66 & 0.50 \\
\hline
\end{tabular}

Oxygen had little or no effect on the lubricity of methanol, but lubricity increased in jet fuels and diesel fuels when the oxygen was removed. The effect of dissolved oxygen on the other alcohols, particularly ethanol, was substantial. Preliminary work has shown that methanol has a relatively high oxidation stability. Because ethanol is more akin to a hydrocarbon, it probably has a lower oxidative stability than 
methanol. Theoretically the oxidation products such as peroxides and carboxylic acids cause metal corrosion, which enhances the wear process.

In conclusion, the lubricity of neat ethanol compares favorably with gasoline, but contamination with water and dissolved oxygen exacerbates the wear in ethanol more so than in gasoline. 


\section{Task 2 Fuel Storage and Handling System Design}

\section{Objective}

The objective of this task was to evaluate material compatibility issues, and specifically to examine ethanol- related wear in fuel injectors.

\section{Discussion of Material Compatibility Issues}

Bourn et al. 1994 listed the materials in the fuel system of the 1993 Ford Taurus FFV, and discussed compatibility with ethanol and ethanol/gasoline blends. The original intent of this task was to ensure that the materials would be compatible with ethanol and ethanol blends through testing and discussions with material experts.

Because of the new enhanced evaporative emissions regulations, many fuel line components used in current FFV, such as the 1993 Ford Taurus FFVs purchased for this project, will not be suitable in future vehicles. For example, fuel lines and elastomers in o-rings in current FFVs have high enough permeability that they will not pass the enhanced evaporative emissions test, according to Ford engineers. Therefore, durability testing with these components, as originally proposed, is no longer suitable. The new materials that will pass enhanced evaporative emissions standards are either still being developed or are proprietary, and are not available for testing. This section summarizes some areas where new materials are required.

Ford staff members were consulted about materials currently used in the Taurus FFV and material changes Ford is making to meet the enhanced evaporative emission standards. Most current materials are unsuitable for the more stringent requirements of the enhanced evaporative standard, and Ford is replacing them with more suitable materials. Several areas are discussed below.

The current fuel tank is a high-density polyethylene with a fluorinated interior surface. This tank will not meet the new standards, and future vehicles will be fitted with a metal tank that may be coated with a plastic or polymer.

Flexible fuel lines used to connect the fuel tank to the fuel lines are a potential problem for evaporative emissions. These lines must be flexible and have $150 \%$ elongation to be crash worthy. Many materials that have the flexibility are permeable and sources of evaporative emissions. The solution to these problems is not known at this time.

Fuel line connectors are sealed using viton o-rings with a high fluorine content. These o-rings have permeability problems. Ford is currently investigating several materials to replace viton in the fuel system. At this time these materials are proprietary.

O-rings and seals currently in the fuel system have been acquired for compatibility testing. Data for elastomer swell for many of the materials have been found, and were included in the design report (Bourn et al. 1994).

The enhanced evaporative standard is apparently forcing the use of new materials. Therefore, the value of testing the current materials is unclear. 
Two components that often give trouble in FFVs are the fuel pumps and the fuel injectors. Although occasional problems have been reported in earlier FFVs when the vehicles are operated on methanol (for which the fuel system was designed), very few problems have been reported with ethanol.

\section{Fuel Injector Wear Testing}

For the above reasons, the focus of the durability testing for this task has been shifted from overall fuel system durability testing to testing fuel injectors and fuel pumps that are not expected to require materials changes for enhanced evaporative emissions. The interest in testing the fuel pumps is strictly durability, but the interest in testing the fuel injectors is fuel leakage and injector performance degradation. There is much current interest in gasoline-fueled engines in leakage past the fuel injector seats when the engine is turned off and the fuel line remains pressurized. The line must remain pressurized to avoid vapor lock (fuel boiling in the line during heat soak-back). Any fuel leaking past the valve seat collects in the intake port and manifold, and introduces a large hydrocarbon spike on the next start-up. This cannot be corrected with fueling strategy, because the amount of leakage is unknown and the engine must be fueled sufficiently to start on the first cylinders to receive fuel.

Researchers must determine whether the ethanol fuel injectors begin to leak more after some usage, and whether they are better or worse than gasoline injectors in their leakage and wear characteristics. A test plan was developed in Phase 2 for these tests based on SAE Procedure J1832 (attached as Appendix B). The testing will be conducted during Phase 3. This procedure provides some guidelines for performing the injector leak rate test, but it also leaves significant room for variations in test procedures between different laboratories.

Several industry sources have suggested that alcohol fuels can affect the durability and performance of fuel injectors. In particular, injectors have been subject to erosion and wear of the nozzle seat and orifices resulting in variation in fuel flow and injector leakage. Experiments will be conducted on E100 and E80 fuels to evaluate their effects on fuel injector performance and durability. As a baseline for comparison, a national average gasoline will be used. The experiments will be conducted in accordance with SAE $\mathrm{J} 1832$.

SAE Standard J1832 specifies test procedures for evaluating gasoline fuel injectors. It covers all aspects of the fuel injectors, including spray distribution and coil dynamics, but only the static flow rate, the dynamic flow, and the seat leakage rate are typically of interest for durability experiments. The static flow rate is the maximum flow of the injector and is achieved when the injector is energized in the fully open position. The dynamic flow is the measured fuel delivered per pulse of the injector when energized at 2.5-ms pulse width (PW) and a 10-ms period.

\section{Test Plan for Fuel Injector Wear Testing}

Test Fuels: The injectors will be evaluated on E100, E80, and a national average gasoline. For performance testing, a standard calibration fluid will be used as the test fluid.

Injectors: Fuel injectors from the Ford Taurus will be used. A minimum of 18 injectors will be tested, six injectors for each fuel.

Performance Parameters: Each injector will be evaluated for static flow rate, dynamic flow, and seat leakage. 
Test Duration: The injectors will be operated for approximately 900 million cycles at a $2.5 \mathrm{~ms} \mathrm{PW}$ and $5 \mathrm{~ms}$ period.

Frequency of Performance Checks: Each injector will be evaluated according to the following schedule:

0 cycles

$100 \times 10^{6}$ cycles

At $100 \times 10^{6}$ cycle intervals until the end of testing.

\section{Alternative Fuels Refueling Conference and Trade Show}

On March 17 and 18, 1994, Terry Gray attended the Alternative Fuels Refueling Conference and Trade Show put on by the Petroleum Equipment Institute (PED) in Orlando, Florida. Technical sessions included discussions of refueling/distribution equipment interface requirements, problems, and successes with each of the alternative fuels (LPG, methanol, ethanol, CNG, and LNG).

More than 700 people attended, representing manufacturers, distributors, installers, and fuel distributors. Most of the exhibits were related to CNG, but alcohol fuel tolerant equipment was shown by several manufacturers of pumps and dispensing equipment. Separate conversations with representatives of Goodyear (hoses), Ford, and the California Energy Commission, as well as information from the sessions, indicated some remaining compatibility issues. However, there was the strong feeling that, once identified, the problems would be solved by the companies involved.

There was also the caution to look at compatibility not only from the standpoint of the fuel's effect on the material, but also from how the fuel might be affected by the interaction. An example is the sensitivity of aluminum to the alcohol fuels, which results not only in corroded aluminum parts, but also in plugged filters and injectors from the aluminum compounds in the fuel.

A significant number of independent fuel distributors in the Midwest install ethanol fuel dispensers in addition to federal, state, and regional programs, so contact with these groups will provide important feedback to this program. 


\section{Task 3 Engine System Assembly and Testing}

\section{Objectives}

There were several objectives of task 3 of Phase 2. First, the 3.0-liter engine needed to be removed from the Ford Taurus FFV, and modified as determined during Phase 1, and detailed in the design report (Bourn et al. 1994). Second, the modified engine had to be mounted in the test cell that had been modified with the addition of a refrigerated chamber. Third, the SwRI RPECS engine controller hardware and software had to be developed sufficiently to perform steady-state testing and cranking/start-up tests. The final objective was to determine minimum timing advance for best torque (MBT) timing, volumetric efficiencies, and other parameters needed by the engine controller, as well as to begin determining start-up strategies.

\section{Engine Test Cell Setup}

Because low-temperature cold-starting is an important issue with alcohol-fueled engines, a refrigeration system and cold box were installed in the test cell. The cold box originally planned for this project was not serviceable, so a new cold box was used along with the existing compressors and heat exchangers. Significant problems have been encountered with leaks in the refrigeration system, but the system with engine installed routinely reached $-18^{\circ} \mathrm{C}\left(0^{\circ} \mathrm{F}\right)$, and on some occasions lower temperatures.

The test cell was set up to accommodate the refrigerated chamber $3.0 \mathrm{~m} \mathrm{x} 3.0 \mathrm{~m} \mathrm{x} 2.4 \mathrm{~m}(10 \mathrm{ft}$. $10 \mathrm{ft}$. $x 8 \mathrm{ft}$.) with the engine installed inside the chamber. The engine cooling system was set up with two completely independent cooling loops. The first cooling loop was used for low-temperature cold starts and consisted of a radiator and fan inside the refrigerated box, a pump to circulate the water even with the engine stopped, and the necessary plumbing. The second system was used for steady-state testing at higher power conditions and used a heat exchanger to cool the engine coolant with water tower cooling water. The engine water pump was used to circulate water in this cooling loop. Thus, the first cooling loop cooled the engine to very cold temperatures for cold starting and low power operation, but could not maintain cold temperatures at higher engine powers. The second loop was the standard cooling loop that could maintain any engine temperature from about $35^{\circ} \mathrm{C}\left(95^{\circ} \mathrm{F}\right)$ to $120^{\circ} \mathrm{C}\left(248^{\circ} \mathrm{F}\right)$ or higher.

The engine is a 3-liter V-6 Ford adapted to run on M85 or gasoline, or any mixture of the two. The principal modifications by the OEM from the gasoline engine include higher flow rate injectors that have materials suitable for alcohol fuels, an extra starting injector that provides high flow rates for lowtemperature starts, and a different ignition system that uses a 36-tooth gear and solid-state ignition. This engine was removed from a vehicle that included an automatic transmission, but it was desirable for test cell operation to include a clutch between the engine and the dynamometer. Unfortunately, the engine block casting is different for Ford 3.0-liter engines that are to be used with automatic and manual transmissions. Therefore, a standard bell housing and clutch cannot be attached to a Ford 3.0-liter built for an automatic transmission. These components had to be constructed that would mate with the existing engine. The clutch is operated with an air solenoid, so the engine may be started without any load, but the load is applied after start-up. The engine is connected through the clutch to a dynamometer and an electric motor. The dynamometer is used to absorb the load from the engine, and the electric motor to motor the engine for various testing.

Fuel flow is read with a MicroMotion Coriolis mass flowmeter. Because Coriolis forces respond to mass flow, the output is not affected by the fuel density, pressure, or temperature. A significant fraction of the 
fuel that flows to the engine is recirculated to the fuel tank, so several pressure regulators and an extra fuel loop were used to measure only the fuel being used by the engine. Both the instantaneous and cumulative fuel mass flows measured by the MicroMotion can be compared with the calculated fuel mass flow in the RPECS engine controller that is derived from the fuel injector pulse width and the fuel differential pressure, with a correction for battery voltage, which affects the injector opening time. These flow rates typically agree to within $10 \%$ or better. Because the fuel can heat up by recirculating through the system if the fuel pump is on but the engine is not running, a heat exchanger with cooling tower water is used to maintain a constant fuel temperature.

Air flow into the engine is measured three different ways. A laminar flow element (LFE) is part of the test cell instrumentation and is sampled as part of the low-speed data acquisition, and is also fed to the RPECS engine controller. The production engine is supplied with a hot-wire mass air flow (MAF) sensor. This signal is filtered using a pi filter as suggested by Ford, and is fed to the RPECS engine controller. The engine has also been fitted with a manifold air pressure (MAP) sensor (a GM production MAP sensor), and this is used to compute air flow by a standard speed-density calculation. A speed-density calculation of air flow multiplies engine speed by engine displacement, volumetric efficiency, and air density in the intake manifold.

The LFE air flow measurement provides an accurate reference for steady-state air flow, but cannot be used on the vehicle. The MAF sensor and the speed-density calculations can be used to compute air flow on the vehicle, with each having advantages and disadvantages compared to the other. The speed-density calculation based on the MAP sensor computes air flow at the intake valves, which is where the fuel is injected and therefore gives a more accurate measure of the air flow to meter the fuel. In contrast, the MAF sensor measures air flow at the throttle plate. However, because the MAF measures air flow upstream of the MAP sensor, it provides some lead-time information that is helpful in transients. In addition, the MAF sensor provides some serendipitous transient fueling compensation, since on tip-ins (accelerations) the intake manifold filling event causes an instantaneously higher flow rate of air at the throttle plate than at the valves. This helps to compensate for the fact that not all the fuel injected makes it directly into the cylinders, as some of it hangs up on the walls.

In addition to these three independent measurements of air flow, a calculation of air flow will be added in the RPECS engine controller based on throttle angle, pressure differential across the throttle plate, and discharge coefficient of the throttle plate as a function of throttle angle and pressure differential. This will be used to compute air flows and manifold air pressure, and it should be possible to compute the values with low noise faster than they can be measured. This is very important to transient compensation.

\section{Engine Modifications}

Bourn et al. (1994), described three modifications as planned for the Ford 3.0-liter engine. All three were carried out as planned. First, the compression ratio was raised from 9.3 to 11.0 by removing some material from the head and from the block, and by including a dome on the piston. Detailed drawings and dimensions were provided in the Design Report, and some of those procedures are also summarized below. Second, air-assist injectors as previously described were mounted onto the engine. Some atomization results are provided below. Third, because of the other engine modifications, the engine could not be operated using the standard Ford EEC IV engine controller. Therefore, a SwRI RPECS was developed for the 3.0-liter engine. Many details of the RPECS control system were described in the Design Report, and further details are provided under Task 6 of this report. 


\section{Increased Compression Ratio}

The engine was removed from the vehicle, disassembled, and modified to increase the compression ratio from 9.3 to 11.0. This modification was to take advantage of the very high octane number of ethanol by improving the cycle efficiency. Typical efficiency increases are $3 \%$ per one unit of compression ratio. The cooling effect of ethanol is also predicted to improve the cycle efficiency by reducing compression work.

Figure 3-1 shows the dimensions of the Ford 3.0-liter reciprocating components and combustion chamber. Table 3-1 shows the calculations based on these dimensions for increased compression ratios. The piston face-to-block deck clearance was $0.49 \mathrm{~mm}(0.019 \mathrm{in}$.) which was reduced by milling the block surface, achieving a zero deck height and removing $3.07 \mathrm{cc}(0.187 \mathrm{ci})$ from the clearance volume. The original cylinder head combustion chamber volume was measured to be $49.6 \mathrm{cc}$ ( $3.03 \mathrm{ci}$ ), and Table 3-1 gives compression ratios corresponding to volume removed from the chamber when the head was milled 0.71 $\mathrm{mm}(0.040 \mathrm{in}$.). Calculations were performed for reducing the clearance volume by machining the cylinder head and block gasket surfaces the maximum safe amount.

Table 3-1. Ford 3.0-liter FFV - Cylinder Modifications.

\begin{tabular}{lccc}
\hline \multicolumn{1}{c}{ Original Dimensions } & \multicolumn{2}{c}{ Modified Dimensions } \\
\hline Combustion Chamber Volume & $48.56 \mathrm{cc}$ & Mill Head 0.71 mm (0.028 in) & $45.06 \mathrm{cc}$ \\
Head Gasket Volume & $7.69 \mathrm{cc}$ & & $7.69 \mathrm{cc}$ \\
Piston-to-Deck Volume & $3.07 \mathrm{cc}$ & Mill Block $0.49 \mathrm{~mm}(0.019 \mathrm{in})$ & $0 \mathrm{cc}$ \\
Ring Crevice Volume & $0.58 \mathrm{cc}$ & & $0.58 \mathrm{cc}$ \\
Valve Relief Volume & $0.34 \mathrm{cc}$ & & $0.34 \mathrm{cc}$ \\
Piston Dome Volume & $0 \mathrm{cc}$ & $1.01 \mathrm{~mm}(0.040 \mathrm{in})$ height & $-4.0 \mathrm{cc}$ \\
Clearance Volume & $60.24 \mathrm{cc}$ & & $47.42 \mathrm{cc}$ \\
Swept Volume & $498.13 \mathrm{cc}$ & & $498.13 \mathrm{cc}$ \\
Compression Ratio & $9.27: 1$ & & $11.03: 1$ \\
\hline
\end{tabular}

A maximum compression ratio of approximately 10.4:1 can be achieved by the machining procedures alone. The target compression ratio of $11: 1$ was achieved by adding pistons with a small dome volume of $4.0 \mathrm{cc}(0.244 \mathrm{ci})$. The combination of cylinder head and block machining and pistons with a very small dome achieved the desired compression ratio for increased engine efficiency while minimizing the quench volume. However, although the increased compression ratio should increase engine efficiency, the hydrocarbon and nitric oxide emissions are expected to increase, making it more difficult to meet ULEV targets. The tradeoff between efficiency and emissions by adjusting compression ratio is fundamental, and therefore, difficult to avoid.

\section{Air-Assist Fuel Injectors}

Air-assist injectors were constructed for this project by fitting fuel-air mixing caps over the OEM FFV fuel injectors. The OEM fuel injectors are pintle injectors suitable in materials of construction and flow rate for alcohol-fueled engines. Fueling rates for M85 are about twice that of gasoline, and fueling rates for ethanol are about 1.6 times that of gasoline. Because the OEM injectors were designed for M85, their flow capacity is oversized for ethanol fuels, but can meet the maximum flow rate requirements. 


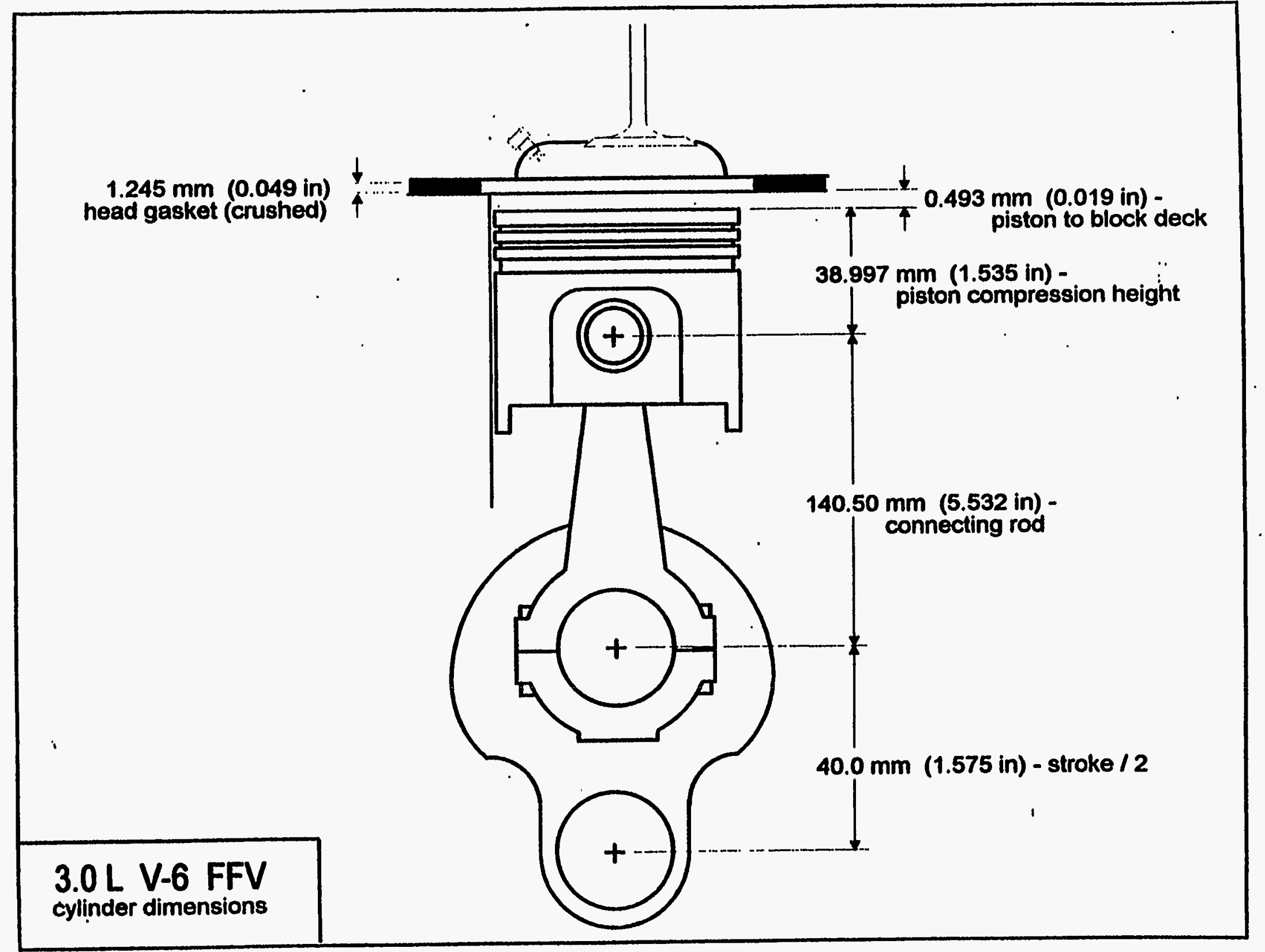

Figure 3-1. PIston and combustlon chamber for Ford Taurus 3.0-llter V-6. 
The fuel-air mixing caps were designed to be used in the standard manifold. However, the injectors had to be raised slightly to accommodate the mixing caps, and this resulted in interference with the intake manifold on one side of the engine. Therefore, a spacer of about $8.1-\mathrm{mm}(0.319 \mathrm{in}$.) thick was added to the intake manifold to provide sufficient clearance for the injectors with the caps. Also, the mounting brackets for the fuel rail had to be modified to account for the slightly raised position of the OEM fuel injectors when the fuel-air mixing caps were added.

A schematic of the fuel-air mixing caps is shown in Figure 3-2. The caps were designed such that the principal air pressure drop is across the 1-mm exit hole from the injector. Therefore, this is an internalmix, air-assist injector design. They have been tested with and without fuel-impingement screens that have been found useful in other injectors. The results reported here are for the design with the impingement screens.

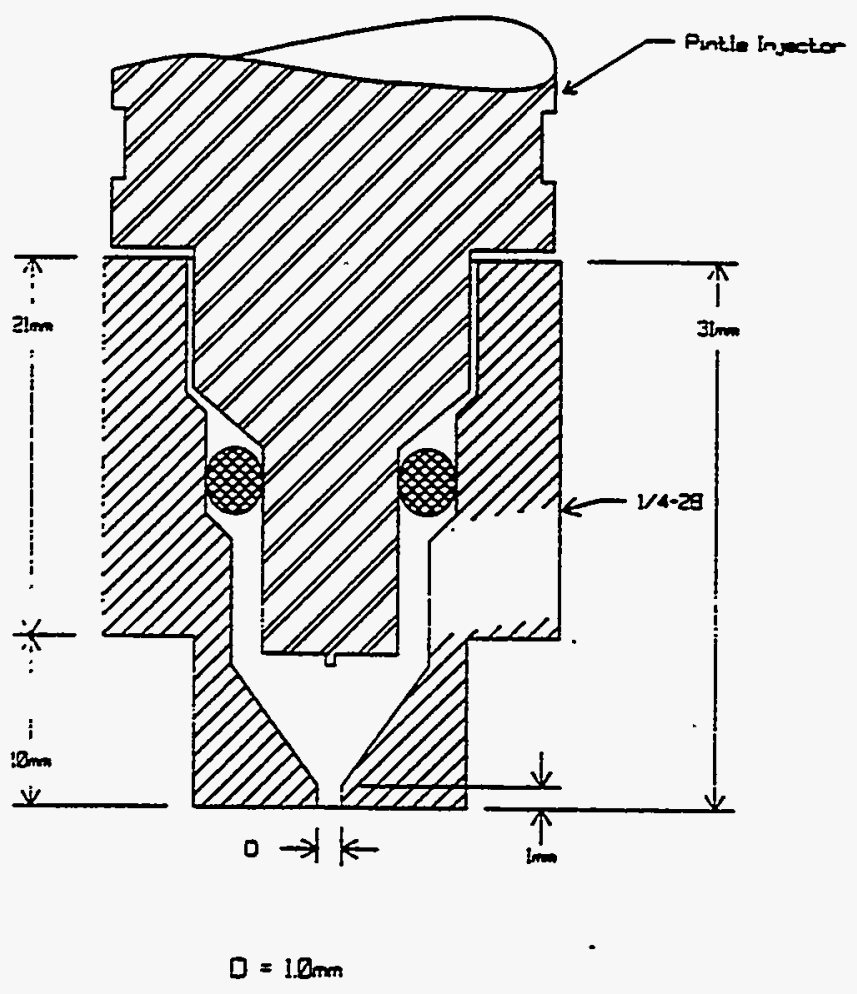

Figure 3-2. SwRI internal-mix air-assist injectors.

Figure 3-3 shows the Sauter mean diameters (SMDs), or surface area-volume mean diameters for three different pulse widths. The pulse width of 3-ms corresponds to an idle condition, 4-ms to a cruise, and $10-\mathrm{ms}$ to an enriched pulse for acceleration or start-up. Compared with the OEM injectors that produce SMDs of about $1 \overline{2} 0 \mu \mathrm{m}$, these injectors produce very fine sprays that will follow the air stream into the cylinder better and evaporate faster than fuel drops from the OEM injectors. However, at all conditions, but especially the 10-ms pulse width, the SMDs are somewhat larger than expected. The relatively poorer performance may result from the much higher flow rate of the fuel injector for the FFV compared to a gasoline injector (sized for more than twice the static flow rate of a gasoline injector, as required for methanol). Another factor is the smaller hole used in the fuel-air mixing cap than on some previous designs. A fuel injector with a smaller static flow rate would still be sufficient for ethanol (but not methanol), but the FFV injectors with materials suitable for alcohols are generally sized for methanol. Larger exit holes on the fuel-air mixing cap improves atomization at the cost of higher air consumption, and therefore, higher fuel usage to generate the power required by the air pump. 


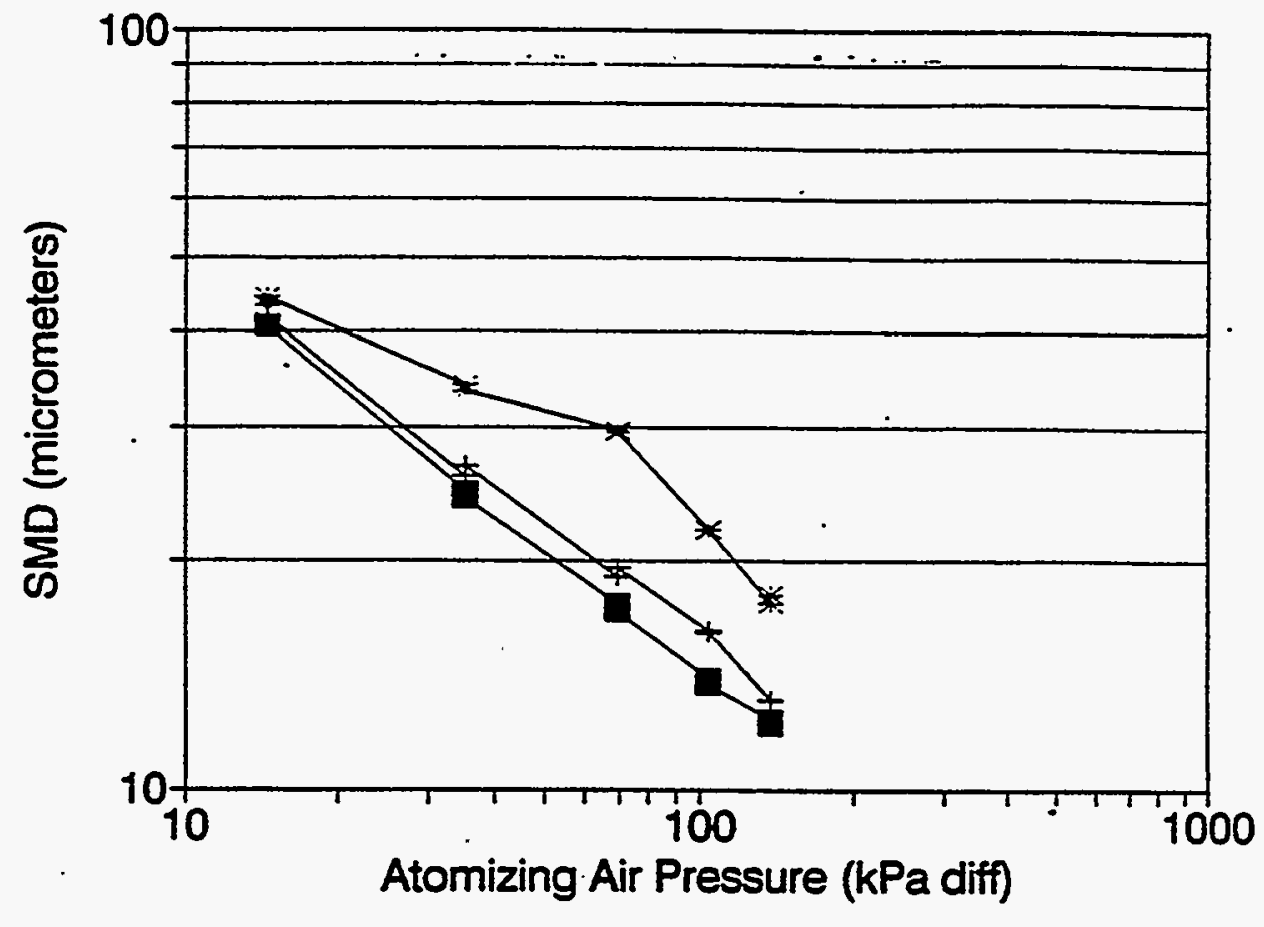

$\rightarrow-3-m s$ P.W., 50-ms Pd 7 4-ms P.W., 50-ms Pd $\rightarrow$ 10-ms P.W. 50-ms Pd

Figure 3-3. Effect of atomizing air pressure on average drop as represented by $\operatorname{SMD}\left(D_{32}\right)$, standard Taurus 3.0-liter flexible fuel injector and fuel-air mixing cap with 1-mm exit hole.

In addition to the atomization characteristics, the fuel delivery characteristics of the injectors are important. Fuel delivery characteristic refers to how quickly and completely the fuel exits from the fuel-air mixing chamber. If there are lags in the fuel delivery, cycle-to-cycle variability for the fuel delivered to the cylinder can be encountered, which results in cycle-to-cycle variations in air-fuel ratio and in power (IMEP). These characteristics will be examined later in the project..

\section{Rapid Prototyping Engine Control System Engine Controller}

Because of the other modifications to the engine described above, we could not use the OEM Ford EEC IV engine controller. Therefore, SwRI adapted an RPECS to the Ford Taurus 3.0-liter engine for complete authority engine control. The cost for hardware and software development was paid mostly from Task 3 funds, but is discussed under Task 6 below. 


\section{Task 4 Emissions Control System Development and Testing}

\section{Objectives}

The objectives of this task were to perform FTP emissions tests on the baseline 1993 Ford Taurus FFV on Ed85 (E80), to modify that vehicle for advanced aftertreatment devices, and to perform the first set of FTP emissions tests on the vehicle with advanced aftertreatment devices.

The following section details the exhaust emissions control efforts undertaken in this program, including:

- Baseline emissions tests

- Advanced aftertreatment system characteristics

- Modifications to vehicle for installing of aftertreatment systems

- Emissions results with electrically heated catalyst/reformulated main catalyst systems

- Future plans

\section{Baseline Emissions Tests}

Southwest Research Institute received two Ford Taurus FFVs in March, 1994. One was designated for use in the emissions control system design task. This vehicle was delivered with 18 miles on the odometer. The oil was replaced with Pertolube purchased for this program, and a new oil filter was installed. The fuel system was drained, and the vehicle was fueled with E80. The vehicle was then driven for 4,000 miles over a modified Automobile Manufacturers Association durability driving schedule before baseline emissions tests were conducted.

Duplicate tests were conducted on the vehicle both with and without a catalytic converter to establish baseline exhaust emissions levels. The vehicle was operated over the chassis dynamometer portion of the Federal Test Procedure (FTP) for light-duty vehicles while operating on E80. Results of these tests are presented in Table 4-1. 
Table 4-1. Baseline Federal Test Procedure Exhaust Emissions from Ford Flexible Fuel Vehicle.

\begin{tabular}{|c|c|c|c|c|}
\hline $\begin{array}{l}\text { Exhaust } \\
\text { Constituents }\end{array}$ & $\begin{array}{l}\text { Without } \\
\text { Catalyst }\end{array}$ & $\begin{array}{c}\text { With } \\
\text { Catalyst }\end{array}$ & TLEV & ULEV \\
\hline $\mathrm{THC}^{\mathrm{a}}(\mathrm{g} / \mathrm{mi})$ & 2.75 & 0.21 & ?. & 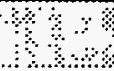 \\
\hline $\mathrm{CO}(\mathrm{g} / \mathrm{mi})$ & 12.71 & 1.90 & 3.4 & 1.7 \\
\hline $\mathrm{NO}_{x}(\mathrm{~g} / \mathrm{mi})$ & 2.03 & 0.10 & 0.4 & 0.2 \\
\hline $\mathrm{CH}_{4}(\mathrm{~g} / \mathrm{mi})$ & 0.09 & 0.05 & & \\
\hline $\mathrm{NMHC}^{\mathrm{b}}(\mathrm{g} / \mathrm{mi})$ & 0.83 & 0.06 & & \\
\hline Carbonyls $^{c}$ (g/mi) & 0.41 & 0.02 & & \\
\hline Alcohols $^{d}(\mathrm{~g} / \mathrm{mi})$ & 1.43 & 0.09 & & \\
\hline Estimated $\mathrm{NMOG}^{\mathrm{e}}(\mathrm{g} / \mathrm{mi})$ & 2.663 & 0.160 & & \\
\hline Est NMOG $\times \operatorname{RAF}^{f}(\mathrm{~g} / \mathrm{mi})$ & 1.784 & 0.107 & 0.125 & 0.040 \\
\hline Formaldehyde (mg/mi) & 122.80 & 1.54 & 15 & 8 \\
\hline Acetaldehyde (mg/mi) & 266.93 & 12.87 & & \\
\hline \multicolumn{5}{|c|}{$\begin{array}{l}\text { a THC = NMOG + } \mathrm{CH} 4 \\
\text { basoline derived NMHC = FIDHC - }\left(\mathrm{CH}_{4} \times \text { FIDRCH4) - (Ethanol x FIDRETH); FIDHC - }\right. \\
\text { hydrocarbon measured with flame ionization detector calibrated on propane; FIDRCH4 - FID } \\
\text { response factor for methane; FIDRETH - FID response factor for ethanol } \\
\text { Summation of all measured aldehydes and ketones including: formaldehyde, acetaldehyde, } \\
\text { acrolein, acetone, propionaldehyde, crotonaldehyde, isobutyraldehyde + methyl ethyl ketone, } \\
\text { and hexanaldehyde }\end{array}$} \\
\hline
\end{tabular}

Exhaust samples were measured for $\mathrm{HC}, \mathrm{CO}, \mathrm{NO}_{\mathrm{x}}, \mathrm{CH}_{4}$, aldehydes and ketones, and alcohols (only ethanol was detected). Nonmethane organic gases (NMOG) were estimated using NMHC from the gasoline portion of the fuel as measured by a flame ionization detector (FD) rather than by hydrocarbon speciation. Gasoline-derived NMHC was determined by measuring hydrocarbons with a FID calibrated on propane, then correcting the results for the removal of $\mathrm{CH}_{4}$ and ethanol.

These data show the unmodified vehicle meets TLEV exhaust emissions standards, and that the vehicle catalyst is quite effective in reducing all exhaust constituents. These low emissions levels were obtained even though the vehicle was calibrated for low emissions on M85 or gasoline, but not on ethanol blends. To better demonstrate where improvements could be made in the efficiency of the catalyst, selected individually weighted emissions for each phase of the FTP are presented in Table 4-2. 


\section{Table 4-2. Weighted Baseline Federal Test Procedure Exhaust Emissions for Ford Flexicble}

Fuel Vehicle with Catalyst.

\begin{tabular}{|c|c|c|c|c|c|c|}
\hline $\begin{array}{l}\text { Exhaust } \\
\text { Emission }\end{array}$ & $\begin{array}{c}\text { Bag 1A } \\
(0-140 \\
\text { sec })\end{array}$ & $\begin{array}{c}\text { Bag 1B } \\
(141-505 \\
\text { sec })\end{array}$ & $\begin{array}{l}\text { hted Ext } \\
\text { (g/mi) }\end{array}$ & Bag 3 & $\begin{array}{c}\text { Total } \\
\text { Weighted } \\
\text { FTP } \\
\text { Emissions } \\
\text { (g/mi) }\end{array}$ & $\begin{array}{c}\text { Bag 1A } \\
\text { Percentage } \\
\text { of Total } \\
\text { NMOG } \\
\text { Emissions }\end{array}$ \\
\hline NMHC & 0.04 & $<0.01$ & $<0.01$ & 0.01 & 0.06 & $27 \%$ \\
\hline Ethanol & 0.09 & $<0.01$ & $<0.01$ & $<0.01$ & 0.09 & $56 \%$ \\
\hline Acetaldehyde & 0.01 & $<0.01$ & $<0.01$ & $<0.01$ & 0.01 & $10 \%$ \\
\hline
\end{tabular}

These data show that unburned ethanol in Bag 1A (first 140 seconds of FTP) accounts for $56 \%$ of all FTP NMOG emissions, and acetaldehyde in Bag $1 \mathrm{~A}$ accounts for approximately $10 \%$ of all NMOG emission.

In addition, Bag $1 \mathrm{~A}$ NMHC emissions contribute $27 \%$ to total NMOG. Thus, approximately $93 \%$ of all NMOG emissions from this vehicle occur in the first 140 seconds of the FTP, of which $66 \%$ are caused by unburned ethanol and acetaldehyde. These data suggested the need for supplemental catalyst heating at vehicle start, to quickly light off the catalyst. In addition, the main catalyst needed to be formulated to specifically target unburned ethanol and acetaldehyde.

\section{Modifications to Vehicle}

To improve the exhaust emissions from the test vehicle, an electrically heated catalyst was obtained from WR Grace, and a main catalyst specially formulated for operation on alcohol vehicles was obtained from Degussa. A summary of catalyst characteristics is presented in Table 4-3.

Table 4-3. Catalyst Characteristics.

\begin{tabular}{|c|c|c|c|c|}
\hline \multirow{2}{*}{$\begin{array}{l}\text { Catalyst System } \\
\text { Catalyst Designation }\end{array}$} & \multicolumn{2}{|c|}{$\begin{array}{c}\text { Ford OEM } \\
\text { (one catalyst per bank) }\end{array}$} & \multirow{2}{*}{$\begin{array}{c}\text { Grace EHC } \\
\text { M930037 Cam-E-Lite }\end{array}$} & \multirow{2}{*}{$\begin{array}{c}\begin{array}{c}\text { Degussa Main } \\
\text { Catalyst }\end{array} \\
\text { OM } 6902 \text { Lot } 40512\end{array}$} \\
\hline & front brick & rear brick & & \\
\hline $\begin{array}{l}\text { Substrate: } \\
\text { Material } \\
\text { Cell Density }\end{array}$ & \multicolumn{2}{|c|}{$\begin{array}{c}\text { ceramic } \\
400 \text { cells/in. }^{2}\end{array}$} & $\begin{array}{l}\text { stainless steel foil } \\
180 \text { cells/in. }^{2}\end{array}$ & $\begin{array}{c}\text { ceramic } \\
400 \text { cells/in. }^{2}\end{array}$ \\
\hline $\begin{array}{l}\text { Precious Metals: } \\
\text { Precious Metals Types } \\
\text { Loading (combined) } \\
\text { Precious Metal Ratio }\end{array}$ & $\begin{array}{c}\mathrm{Pt} / \mathrm{Rh} \\
60 \mathrm{~g} / \mathrm{ft}^{3} \\
\mathrm{Pt} / \mathrm{Rh}=9 / 1\end{array}$ & $\begin{array}{c}\mathrm{Pt} / \mathrm{Rh} \\
28 \mathrm{~g} / \mathrm{ft}^{3} \\
\mathrm{Pt} / \mathrm{Rh}=5 / 1\end{array}$ & $\begin{array}{c}\mathrm{Pt} / \mathrm{Rh} \\
80 \mathrm{~g} / \mathrm{ft}^{3} \\
\mathrm{Pt} / \mathrm{Rh}=5 / 1\end{array}$ & $\begin{array}{c}\mathrm{Pt} / \mathrm{Rh} \\
70 \mathrm{~g} / \mathrm{ft}^{3} \\
\mathrm{Pt} / \mathrm{Rh}=5 / 1\end{array}$ \\
\hline Core Length & NA & NA & $\begin{array}{l}5.5 \text { in. } \\
\text { (front } 0.7 \text { in. heated) }\end{array}$ & 6.0 in. \\
\hline Core Diameter & NA & NA & $2.7 \mathrm{in.}$ & 5.66 in. \\
\hline Brick Active Volume & 38 in. $^{3}$ & 38 in. $^{3}$ & 31.5 in. $^{3}$ & 151 in. $^{3}$ \\
\hline Total Active Volume & \multicolumn{2}{|c|}{152 in. $^{3}$} & 31.5 in. $^{3}$ & 151 in. $^{3}$ \\
\hline
\end{tabular}


The test vehicle was fitted with an exhaust system modified to accommodate the reformulated main catalyst and EHC. Because of space constraints under the vehicle and the large diameter of the reformulated main catalyst, it was installed much further downstream in the exhaust system than the OEM catalysts. Figure 4-1 shows the OEM and experimental exhaust system configurations. The twin OEM catalysts both reside approximately $355 \mathrm{~mm}$ (14 inches) downstream of the exhaust manifold flange. In the experimental exhaust system, blank pipes are installed where the OEM catalysts were, and the $\mathrm{EHC} /$ reformulated main catalyst set is installed at the termination of the Y-pipe. This places the face of the reformulated main catalyst approximately $940 \mathrm{~mm}$ (37 inches) from the exhaust manifold flange on one side of the exhaust system, and $1.47 \mathrm{~mm}$ (58 inches) downstream of the manifold flange on the other side. To compensate for the heat loss, the exhaust system was wrapped with insulated fiber tape from the exhaust manifold flange to the end of the Y-pipe. 


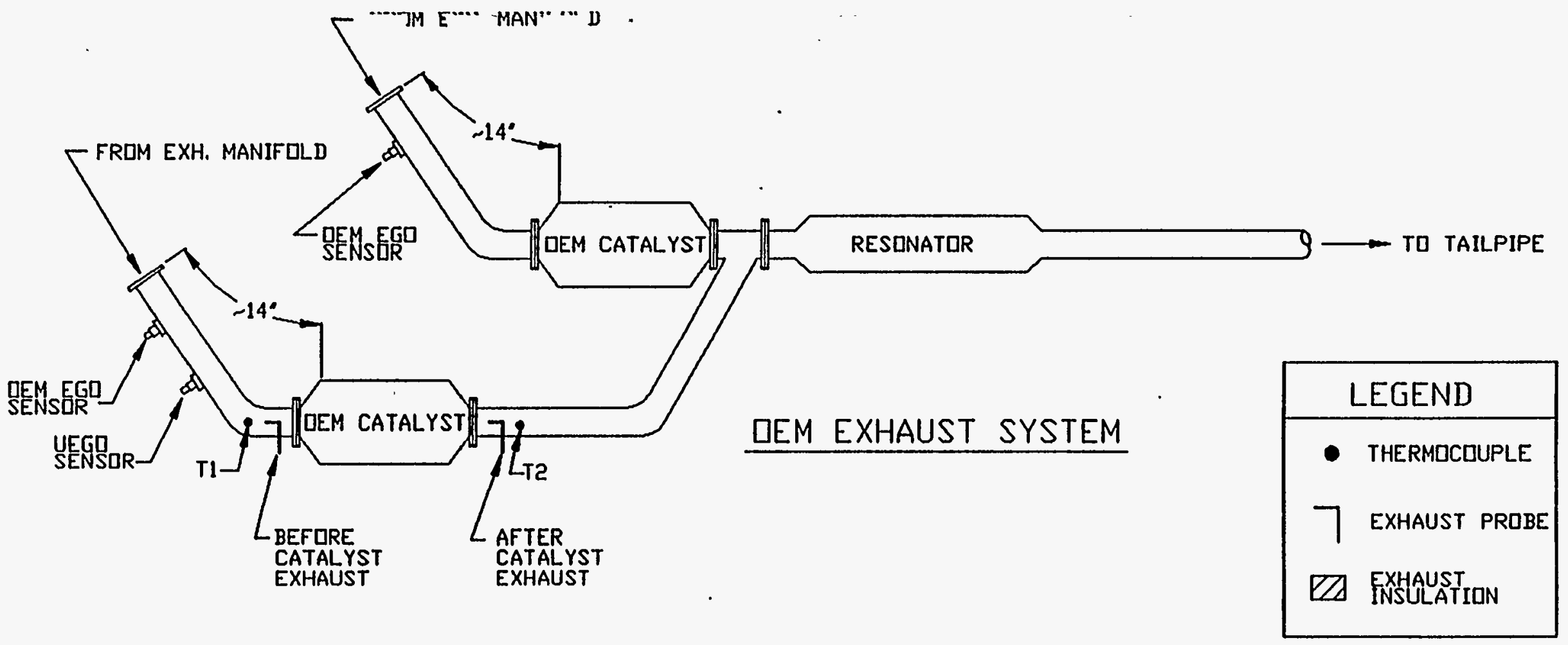

ก

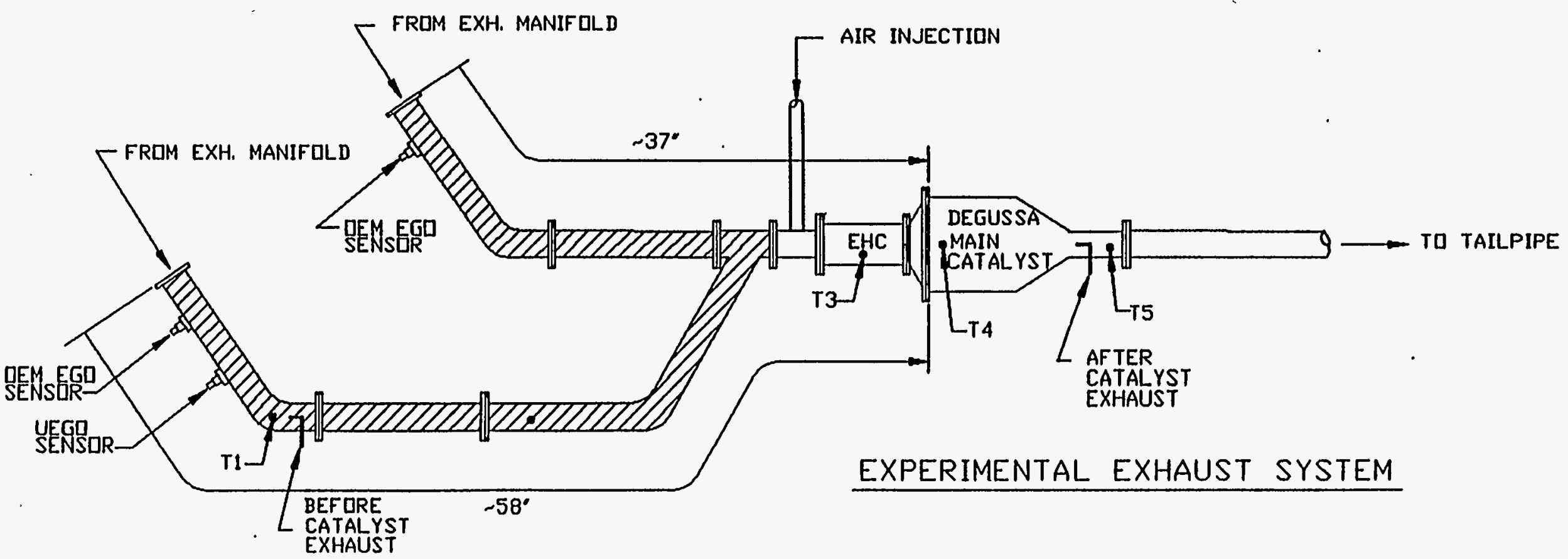

Figure 4-1. Schematlc of standard OEM exhaust system and SwRI experImental exhaust system. 


\section{Electrically Heated Catalyst Emissions Testing}

After work on the exhaust system was completed, the vehicle was prepared for a series of FTP tests to determine the effect of the EHC/reformulated main catalyst system on exhaust emissions. First, the OEM exhaust system was installed on the vehicle to establish a current baseline for exhaust emissions. Then the fuel composition sensor was replaced with a SwRI-generated signal calibrated for E80. The OEM sensor was calibrated for methanol, and would cause over-enrichment during open-loop operation of the vehicle when running on E80. The SwRI circuit was calibrated to provide an appropriate amount of openloop fuel enrichment for E80. Lastly, the experimental exhaust system was installed incrementally to determine the impact of each component on exhaust emissions. The EHC was operated in a post-crank heating mode. Secondary air was injected for the duration of open-loop operation. A series of three tests were conducted to determine an appropriate air injection flow rate. A summary of the test matrix is given in Table 4-4.

Table 4-4. Emissions Test Matrix.

\begin{tabular}{|c|c|c|c|c|c|c|}
\hline Test Number & Catalyst & $\begin{array}{l}\text { Fuel } \\
\text { Sensor } \\
\text { Signal }\end{array}$ & $\begin{array}{l}\text { Exhaust } \\
\text { Insulation }\end{array}$ & $E H C$ & EHC Power & Secondary Air injection \\
\hline E80-OEM-1 & OEM & OEM & no & no & none & none \\
\hline E80-OEM-2 & OEM & SwRI & no & no & none & none \\
\hline E80-CAT-A & Degussa & SwRI & no & no & none & none \\
\hline E80-CAT-A\&INS & Degussa & SwRI & yes & no & none & none \\
\hline E80-CAT-A\&B & Degussa & SwRI & yes & yes & none & none \\
\hline E80-EHC-7CFM & Degussa & SwRI & yes & yes & $\begin{array}{l}\text { Bag } 1-25 \mathrm{sec} \\
\text { Bag } 3-10 \mathrm{sec}\end{array}$ & $\begin{array}{l}\text { Bag } 1-115 \mathrm{sec} @ 7 \mathrm{~cm} \\
\text { Bag } 3-10 \mathrm{sec} @ 7 \mathrm{~cm}\end{array}$ \\
\hline E80-EHC-5CFM & Degussa & SwRI & yes & yes & $\begin{array}{l}\text { Bag } 1-25 \mathrm{sec} \\
\text { Bag } 3-10 \mathrm{sec}\end{array}$ & $\begin{array}{l}\text { Bag 1-115 sec } 15 \mathrm{~cm} \\
\text { Bag } 3-10 \mathrm{sec} @ 5 \mathrm{cfm}\end{array}$ \\
\hline E80-EHC-2CFM & Degussa & SwRI & yes & yes & $\begin{array}{l}\text { Bag } 1-25 \mathrm{sec} \\
\text { Bag } 3-10 \mathrm{sec}\end{array}$ & $\begin{array}{l}\text { Bag } 1-115 \mathrm{sec} @ 2 \mathrm{cfm} \\
\text { Bag } 3-10 \mathrm{sec} @ 2 \mathrm{cfm}\end{array}$ \\
\hline
\end{tabular}

Results of the exhaust emissions tests conducted to date are given in Table 45. 
Table 4-5. FTP Exhaust Emissions from FFV Taurus on E80.

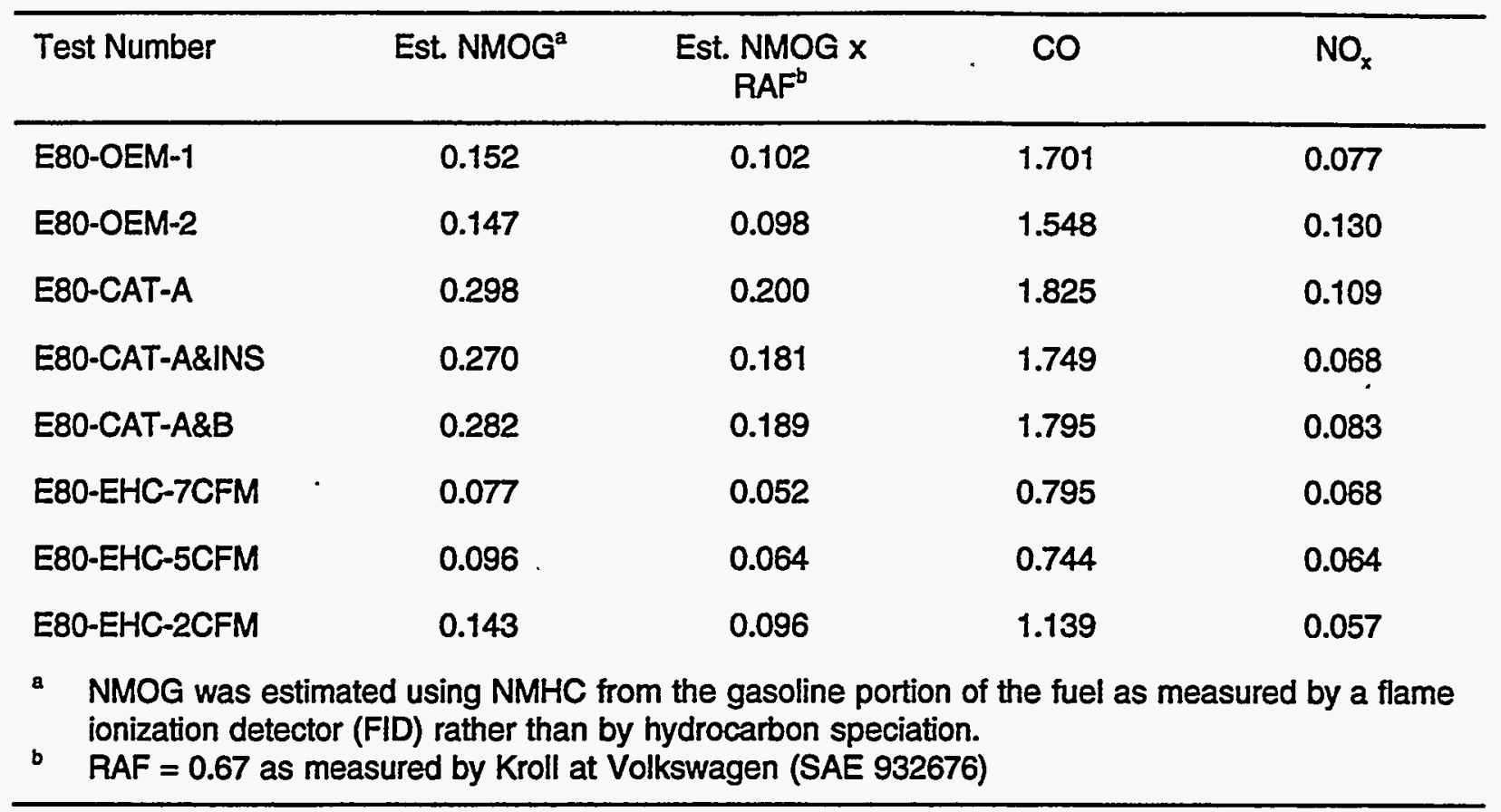

Comparing the OEM baseline test (E80-OEM-1) with E80-OEM-2, the SwRI-generated fuel sensor signal had a slight positive impact on measured NMOG and CO emissions; however, a slight increase in $\mathrm{NO}_{x}$ emissions was detected. Therefore, it seems likely that the change to the SwRI-generated fuel sensor signal caused the vehicle to operate with less open-loop enrichment than in OEM configuration. A change from the OEM exhaust system to the experimental exhaust system with reformulated main catalyst led to a significant increase in NMOG emissions, as shown by the results of test E80-CAT-A (Table 4-5). A combination of less available thermal energy (due to the placement of the catalyst) and the catalyst formulation likely contributed to the higher emissions results for the reformulated main catalyst as compared to the baseline OEM exhaust emission results. The addition of exhaust insulation in test E80CAT-A\&INS resulted in a reduction of all exhaust emissions. Results from test E80-CAT-A\&B show that the addition of the EHC (no heat, no air injection) into the exhaust stream had little effect on exhaust emissions. With the EHC operational in test E80-EHC-7CFM, measured exhaust emissions were reduced significantly from the non-heated configuration (E80-CAT-A\&B). Furthermore, emissions were reduced from OEM baseline levels. During this test, secondary air was injected into the exhaust stream ahead of the EHC at a constant flow fare of $7 \mathrm{cfm}$. Tests were also conducted with 5-cfm and 2-cfm flow rates; however, emissions results from these tests were not as favorable as at $7 \mathrm{~cm}$.

Detailed results from the baseline test (OEM-1) and the best results with the EHC (E80-EHC-7CFM) are give in Table 4-6. These data show significant reductions in exhaust emissions with the use of the EHC together with a reformulated main catalyst. Estimated NMOG was reduced by nearly $50 \%$, and alcohol emissions were reduced by approximately $65 \%$. However, although aftertreatment technology has demonstrated gains in control of exhaust emissions, further improvements are needed to meet ULEV standards. 
Table 4-6. FTP Exhaust Emissions from Ford FFV.

\begin{tabular}{|c|c|c|c|c|}
\hline $\begin{array}{l}\text { Exhaust } \\
\text { Constituents }\end{array}$ & $\begin{array}{c}\text { Baseline } \\
\text { Test \# } \\
\text { E80-OEM-1 }\end{array}$ & $\begin{array}{c}\text { EHC Test \# } \\
\text { E80-EHC- } \\
\text { 7CFM }\end{array}$ & $\begin{array}{c}\text { Percent } \\
\text { Reduction with } \\
\text { EHC }\end{array}$ & $\begin{array}{r}\text { ULEV } \\
\text { Standards }\end{array}$ \\
\hline $\mathrm{THC}^{\mathrm{a}}$ (g/mi) & 0.196 & 0.123 & 37.2 & 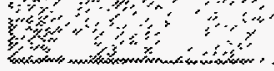 \\
\hline $\mathrm{CO}(\mathrm{g} / \mathrm{mi})$ & 1.702 & 0.796 & 53.2 & 1.7 \\
\hline $\mathrm{NO}_{x}(\mathrm{~g} / \mathrm{mi})$ & 0.077 & 0.068 & 11.7 & 0.2 \\
\hline $\mathrm{CH}_{4}(\mathrm{~g} / \mathrm{mi})$ & 0.044 & 0.046 & -4.5 & \\
\hline $\mathrm{NMHC}^{b}(g / \mathrm{mi})$ & 0.047 & 0.033 & 29.8 & \\
\hline Carbonyls $(\mathrm{g} / \mathrm{mi})$ & 0.014 & 0.012 & 14.3 & \\
\hline Alcohols ${ }^{d}(g / m i)$ & 0.091 & 0.032 & 64.8 & \\
\hline Estimated NMOG' $(g / m i)$ & 0.152 & 0.077 & 49.3 & \\
\hline Est NMOG $\times$ RAF $^{f}(g / m i)$ & 0.102 & 0.052 & 49.0 & 0.040 \\
\hline Formaldehyde (mg/mi) & 1.49 & 0.58 & 61.1 & 8 \\
\hline Acetaldehyde (mg/mi) & 11.19 & 10.93 & 2.3 & $y$ \\
\hline \multicolumn{5}{|c|}{$\begin{array}{l}\text { THC = NMOG + CH4 } \\
\text { Gasoline derived NMHC = FIDHC - }\left(\mathrm{CH}_{4} \times \text { FIDRCH4) - (Ethanol x FIDRETH); FIDHC - }\right. \\
\text { hydrocarbon measured with flame ionization detector calibrated on propane; FIDRCH4 - FID } \\
\text { response factor for methane; FIDRETH - FID response factor for ethanol } \\
\text { Summation of all measured aldehydes and ketones including: formaldehyde, acetaldehyde, } \\
\text { acrolein, acetone, propionaldehyde, crotonaldehyde, isobutyraldehyde + methyl ethyl ketone, and } \\
\text { hexanaldehyde }\end{array}$} \\
\hline
\end{tabular}

Table 47 gives individually weighted emissions for each phase of the FTP. These data show that, even with an EHC, nearly 70\% of all NMOG emissions are caused by unburned gasoline-derived NMHC and unburned ethanol present during the first 140 seconds of the FTP. These data also show that after 140 seconds, tailpipe exhaust emissions are well controlled, primarily because the catalyst is completely "lit off" and catalyst conversion efficiency is high. Therefore, a method needs to be developed to either bring the complete catalyst to light-off quicker, or momentarily "store" exhaust emissions until the catalyst is completely lit off. 
Table 4-7. Weighted FTP Exhaust Emissions - EHC Test \# E80-EHC-7CFM.

\begin{tabular}{|c|c|c|c|c|c|c|}
\hline \multirow[b]{2}{*}{$\begin{array}{l}\text { Exhaust } \\
\text { Emission }\end{array}$} & \multicolumn{4}{|c|}{ Individually Weighted Exhaust Emissions ( $\mathrm{g} / \mathrm{mi}$ ) } & \multirow[b]{2}{*}{$\begin{array}{c}\text { Total } \\
\text { Weighted } \\
\text { FTP } \\
\text { Emissions } \\
\text { (g/mi) }\end{array}$} & \multirow[b]{2}{*}{$\begin{array}{c}\text { Bag 1A } \\
\text { Percentage } \\
\text { of Total NMOG } \\
\text { Emissions }\end{array}$} \\
\hline & $\begin{array}{c}\text { Bag 1A } \\
(0-140 \text { sec })\end{array}$ & $\begin{array}{c}\text { Bag 1B } \\
(141-505 \\
\text { sec) } \\
\end{array}$ & Bag 2 & Bag & & \\
\hline NMHC & 0.02 & 0.01 & $<0.01$ & $<0.01$ & 0.033 & $27 \%$ \\
\hline Ethanol & 0.03 & $<0.01$ & $<0.01$ & $<0.01$ & 0.032 & $42 \%$ \\
\hline Acetaldehyde & 0.01 & $<0.01$ & $<0.01$ & $<0.01$ & 0.011 & $13 \%$ \\
\hline
\end{tabular}

\section{Future Plans}

To further reduce exhaust emissions in the first few minutes of the FTP, SwRI will investigate hydrocarbon adsorber technologies. Degussa has an aftertreatment technology that combines the functions of a hydrocarbon adsorber and a light-off catalyst. This unit would capture the hydrocarbon emissions from the vehicle during cold start while the catalytic material reached light-off temperature. The hydrocarbons would then be desorbed and reduced by the catalytic material in the unit. The main catalyst would continue to provide exhaust emission reductions. In addition, the EHC system may be supplemented with a small hydrocarbon adsorber. This adsorber could be placed ahead of the EHC to trap cranking and start emissions before the EHC is at operating temperature. Therefore, SwRI plans to test both an EHC with reformulated main catalyst supplemented by hydrocarbon adsorber, and a hydrocarbon adsorber/light-off catalyst with reformulated main catalyst during Phase 3. 


\section{Task 5 Fuel/Engine/Vehicle System Integration}

\section{Objectives}

The objective of this task is to manage the overall project, and modify the vehicle as necessary to support engine modifications.

\section{Air Pumps for Air-Assist Atomizers and Electrically Heated Catalyst}

The atomizer tests described in Task 3 help to define the size of the air pump that will be required to provide atomizing air flow. Similarly, tests with the aftertreatment systems will determine the size of the air pump required for adding air between the engine and catalyst during the warm-up phase to reduce catalyst warm-up time by supplying excess fuel (relative to engine needs) from the engine controller, and air from the auxiliary air pump.

A Thomas air pump has been obtained from Ford for testing to supply air for the air-assist injectors. The pump was sized for air-assist injectors for a 4-cylinder engine rather than a 6-cylinder like the Taurus 3.0liter, and the capacity appears to be undersized. However, the Thomas pump will be used to evaluate its performance.

\section{Flexible Fuel Vehicle Fuel Sensor}

The fuel sensor in the 1993 Ford Taurus FFV was designed to operate on M85 or gasoline, or any blend or M85 and gasoline. It was not designed to operate on ethanol or ethanol/gasoline fuel blends; however, it responds for ethanol fuels roughly correctly for the desired open-loop fueling needed.

Ford supplied confidential information for the fuel sensor response expected for both ethanol/gasoline blends and methanol/gasoline blends. Based on the supplied data, the sensor response for E80 should result in the engine controller (EEC-IV) supplying too much E80 fuel during open-loop operation of the vehicle. Therefore, tests were performed where the fuel sensor signal was replaced with a constant frequency signal to more accurately meter the E80 fuel during open-loop operation. During closed-loop operation on the exhaust oxygen sensor, the error in open-loop operation should not have an impact on engine emissions. Emissions tests described under Task 4 showed little improvement when the fuel signal was corrected, although the change was in the direction expected with slightly lower carbon monoxide and slightly higher nitric oxides. These tests appeared to demonstrate that the adaptive learning algorithms in the OEM Ford Taurus FFV were quite adept at correcting for the error in the signal from the fuel sensor based on closed-loop feedback from the EGO sensor in the exhaust. 


\section{Task 6 Integrated Fuel/Engine System Optimization}

\section{Objective}

The objective of this task was to develop a SwRI RPECS (Rapid Prototyping Engine Control System) engine controller for complete control of all engine functions. This is not a device that modifies signals being sent to the OEM engine controller; rather it completely replaces that controller. This is a shared task between Task 3 and Task 6 of this project.

\section{Rapid Prototyping Engine Control System Engine Controller Hardware}

The hardware for the RPECS engine controller was constructed as planned in described by Bourn et al. (1994). This is basically a PC-based engine controller that uses the PC for higher-level logic development that is programmed in C-code, and for input and output from the engine controller. However, many lower-level, engine specific tasks are off-loaded to a Silicon Systems 67F687 engine controller chip.

The engine test cell version of this controller is shown in Figure 6-1. The key to this setup is the realtime operating system extensions together with the custom boards. The custom boards off-load the most time-critical engine control operations, such as injector and ignition timing. Because of this reduction in the PC's timing requirements, all control codes may be written in the high-level language $\mathrm{C}$. In this way, new control strategies may be very efficiently and quickly implemented and tested.

\section{Rapid Prototyping Engine Control System Engine Controller Software}

Software development for the PC-based, engine-test cell custom engine controller sufficient to run the engine was completed. The initial features set in the controller include:

* Open-loop fueling computed using either a mass airflow sensor or speed-density. A combination of mass air flow (MAF) or speed-density may also be used, with the method chosen based on current engine operating conditions.

* Closed-loop fueling with wide-range UEGO feedback.

* Cylinder-event based control during start-up. Allows for cylinder event by cylinder event based control of fueling and spark timing.

* Air-assist or OEM injector control.

As features are added to the software, they are being tested on the hardware in the Controls Laboratory, using a $68 \mathrm{HC} 11 \mathrm{EVB} 2$ board to simulate the crank/cam pulses from the engine, and using power resistors/LEDs to simulate the injectors, ignition coils, idle-air control and EGR valves.

Model-based control will be developed and implemented into the engine controller in the future. This approach uses mean-value models for both air flow and fuel flow into the engine. 


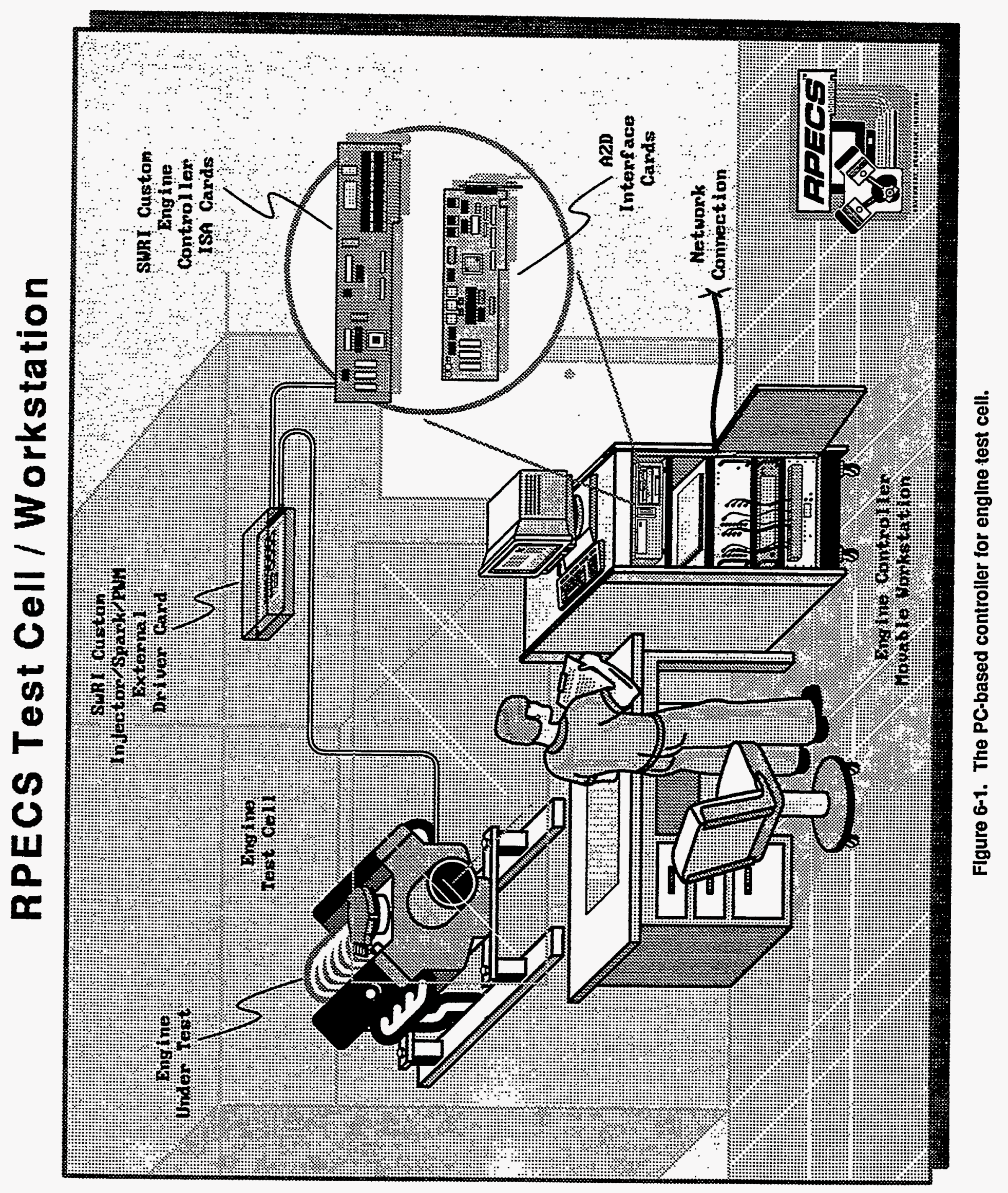




\section{References}

Bourn, G.D.; Callahan, T.J.; Dodge, L.G.; Mulik, J.; Naegeli, D.W.; Shouse, K.R.; Smith, L.R.; Whitney, K.A. (February 1994). Development of a Dedicated Ethanol Ultra-Low Emission Vehicle (ULEV) - System Design, Subcontract No. YAW-3-12243-01. Work performed by Southwest Research Institute, San Antonio, Texas.

Coward, H.F.; Jones, G.W. (1952). Bureau of Mines Bulletin 503, pp. 2, 84, 131.

Fanick, E.R.; Smith, L.R.; Russell, J.A.; Likos, W.E.; Ahuja, M. (October 1990). "Laboratory Evaluation of Safety-Related Additives for Neat Methanol Fuel," SAE Paper No. 902156. Presented at the International Fuels and Lubricants Meeting and Exposition, Tulsa, Oklahoma.

Goodger, E.M. (1980). Alternative Fuels. London: Halsted Press.

Hodgman, C.D. (1957-1958). Handbook of Chemistry and Physics, 39th Ed.

Lawson, A.; Simmons, E.W.; Athey, J.A.B. (March 1987). Safety Aspects of the Use of Alcohol Fuels in Road Vehicles, Phase 1," Final Report No. 4439. Celanese Canada Inc., Engineering Sciences Division, Centre for Alternative Fuel Utilization.

Marshall, W. (1995). Personal conversation. Recent testing at National Institute for Petroleum and Energy Research (NIPER), BDM Oklahoma, on a fleet of several cars fueled by E85 has resulted in a suggested ozone forming reactivity factor for ethanol-fueled exhaust of 0.68 .

Naegeli,' D.W.; Weatherford, W.D. (1989). "Practical Ignition Limits for Low Molecular Weight Alcohols." Fuel 68, 45-48.

van Dolah,.R.W.; Zabetakis, M.G.; Burgess, D.S.; Scott, G.S. (1963). Bureau of Mines, Information Circular 8137, p. 5 .

Zabetakis, M.G. (1952). Bureau of Mines Bulletin 647, pp. 3, 20. 
Appendix A

Standard Specification for Fuel Ethanol (Ed85-Ed75) for Automotive Spark-Ignition Engines (Draft ASTM Standard) 
THIS DOCNAET IS MOT AN ASTM STANDARD. IT IS UNDER CONSIDERATION HITHIN AM ASTM TECHMICAL CONITTEE QUT HAS NOT RECEIVED ALL APPRONALS RECUIRED TO BECONE AN ASTM STANDADD. IT SHALL NOT BE REPRCOUCED OR CIRCULATED OR CWTED, IH HHOL OR IN PART, OUTSIDE OF ASTh COAITTEE ACTIVITIES EXCEPT UITH THE

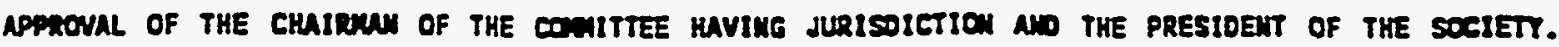
COPTRIGHT AST, 1996 RACE STREET, PHILUELLPIA, PA 19013. ALL RIGHTS RESERVE.

Page 1 of 15

$D-2 D X X X X$ (Draft of $2 / 28 / 95$ )

Standard Specification for Fuel Ethanol (Ed85-Ed75) for Automotive Spark-Ingition Engines:

\section{Scope}

1.1 This specification covers a fuel blend, nominally 85 to 75 volume 8 denatured fuel ethanol and 15 to 25 additional volume \& hydrocarbons for use in ground vehicies with automotive spark-ignition engines. Appendix $X I$ discusses the significance of the properties specified.

1.2 The values stated in Si units are to be regarded as the standard. Values given in parentheses are provided for information only.

1.3 The following precautionary caveat pertains only to the test method portion. Annex Al of this proposed specification.

This standard does not purport to address all of the safety concerns, if any, associated with its use. It is the responsibility of the user of this standard to establish appropriate safety and health practices and determine the applicability of regulatory limitations prior to use.

2. Referenced Documents ${ }^{2}$

\subsection{ASTM Standards:}

D 86 Test Method for Distillation of Petroleum Products ${ }^{3}$

D 130 Test Method for Detection of Copper Corrosion from Petroleum Products by the Copper Strip Tarnish test ${ }^{3}$

D 381 Test Method for Existent Gum in Fuels by Jet Evaporation?

D 512 Test Methods for Chloride Ion in Water"

D 525 Test Method for Oxidation of Gasoline (Induction Period Method) 3

D 1193 Specification for Reagent Water"

D 1265 Test Method for Sulfur in Petroleum Products (Lamp Method)'

D 1613 Test Method for Acidity in Volatile Solvents and Chemical Intermediates Used in Paint. Varnish, Lacquer, and Related Products'

D 1688 Test Method for Copper in Water"

D 2622 Test Method for Sulfur in Petroleum Products by X-Ray Spectrometry Method"

D 2988 Test Method for Water-Soluble Halide Ion in Halogenated Organic Solvents and Their Admixtures?

D 3120 Test Method for Trace Quantities of Sulfur in Light Liquid Petroleum Hydrocarbons by Oxidative Mierocoulometry"

D 3231 Test Method for Phosphorus in Gasoline"

D 3545 Test Method for Alcohol Content and Purity of Acetate Esters by Gas Chromatographys

D 4057 Practice for Manual Sampling of Petroleum and Petroleum Products

D 4177 Method for Automatic Sampling of Petroleum and Petroleum Products" 
D 4307 Practice for Preparation of Liquid Blends for Use as Analytical Standards"

D 4626 Practice for Calculation of Gas Chromatographic Response Factors"

D 4806 Specification for Denatured Fuel Ethanol for Blending with Gasolines for use as Automotive Spark-Ignition Engine Fuel ${ }^{3}$

D 4814 Specification for Automotive Spark-Ignition Engine Fuel ${ }^{3}$

D 4815 Test Method for Determination of MTBE, ETBE. TAME, DIPE, tertiary-Amyl Alcohol and $\mathrm{Cl}$ to $\mathrm{C} 4$ Alcohols in Gasoline by Gas Chromatography"

D 4929 Test Methods for Determination of Organic Chloride Content in Crude Oil:

D 4953 Test Method for Vapor Pressure of Gasoline and Gasoline-Oxygenate Blends (Dry Method)"

D 5059 Test Method for Lead in Gasoline by X-ray Spectroscopy"

D 5190 Test Method for Vapor Pressure of Petroleum Products (Automatic Method)"

D 5191 Test Method for Vapor Pressure of Petroleum Products (Mini Method)

D 5453 Test Method for Determination of Total Sulfur in Light Hydrocarbons, Motor Fuels and Oils by Ultraviolet Fluorescence?

D 5501 Test Method for the Determination of Ethanol Content of Denatured Fuel Ethanol by Gas Chromatography"

E 203 Test Method for Water Using Karl Fischer Reagent?

\section{Terminology}

3.1 Definitions:

3.1.1 ethanol, $n$-ethyl alcohol, the chemical compound $\mathrm{C}_{2} \mathrm{H}_{5} \mathrm{OH}$.

3.1 .2 methanol, n -methyl alcohol, the chemical compound $\mathrm{CH}_{3} \mathrm{OH}$.

3.2 Description of Terms Specific to this Standard:

3.2.1 denaturants, - gasoline, toxic or noxious materials added to ethanol to make it unsuitable for beverage use and suitable for automotive fuel use.

3.2.2 denatured fuel ethanol, -fuel ethanol made unfit for beverage use by the addition of toxic or noxious materials.

3.2.3 fuel ethanol,-ethanol with impurities common to its production (including water but excluding denaturants).

3.2.4 fuel ethanol (Ed85-Ed75),-blend of ethanol and hydrocarboh of which the ethanol portion is nominally 85 to 75 volume \& denatured fuel. ethanol.

3.2.5 hiatier alcohols,-aliphatic alcohols of general formula $\mathrm{C}(\mathrm{N}) \mathrm{H}(2 \mathrm{~N}+1) \mathrm{OH}$ with $\mathrm{N}$ being 3 to 8 .

3.2.6 hydrocarbon,-those components in an ethanol-hydrocarbon blend containing only hydrogen and carbon 


\section{Fuel Ethanol (Ed85-Ed75) Performance Requirements}

4.1 Fuel Ethanol (Ed85-Ed75) shall conform to the following requirements:

Ethanol plus higher alcohois minimum volume of (see 4.1.1 for Volatility Class Criteria)

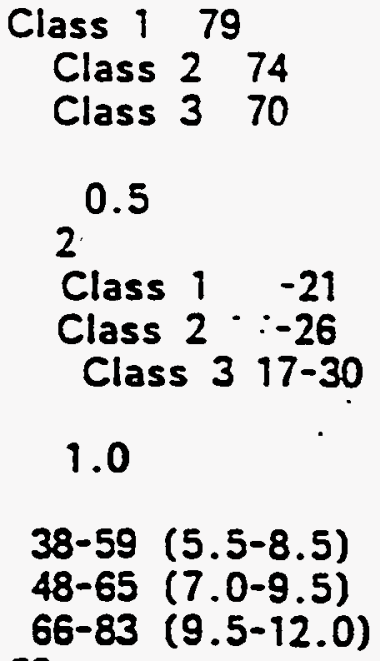$$
0.5
$$

2

Class $1 \quad-21$

Class $2 \cdot \because-26$

Class $3 \quad 17-30$

1.0$$
38-59(5.5-8.5)
$$

$48-65(7.0-9.5)$

$66-83(9.5-12.0)$

Methanol

maximum, volume \&

Higher aliphatic alcohols (C3-C8), Max, Vols

Hydrocarbon (including denaturant)/aliphatic ether blends containing up to 2.7

weight oxygen, volume \&

Water maximum, mass \&

Vapor pressure, $\mathrm{KPa}$ (psi)

$$
\begin{aligned}
& \text { Class } 1 \\
& \text { Class } 2 \\
& \text { Class } 3
\end{aligned}
$$

Acidity as acetic acid maximum, mg/kg

Gum Content, Solvent Washed, maximum, $\mathrm{mg} / 100 \mathrm{~mL}$

Gum Content. Unwashed, maximum, $\mathrm{mg} / 100 \mathrm{~mL}$

Total Chlorine as Chlorides maximum, mg/kg

Inorganic Chloride maximum, mg/kg

Lead maximum, mg/litre

Phosphorus

maximum, mg/litre

Copper. maximum, mg/litre

Sulfur maximum, mg/kg

Appearance
50

5

20

2

1

Class 12.6

Class 22.6

Class 33.9

Class 10.3

Class 20.3

Class 30.4

0.07

Class 1210

Class 2260

Class 3300

The product shall be visibly free of suspended or precipitated contaminants (elear and 
bright). This shall be determined at ambient temperature or 21 Deg. C (70 Deg. F), whichever is higher.

NOTE 1 - Most of the requirements cited are based on the best technical information currently available. Requirements for suifur, phosphorus, and lead are based on the use of gasoline defined in Specification D 4814 and the understanding that control of these elements will affect catalyst lifetime. The lead maximum is limited for Class 1 and Class 2 fuels to the lower limit of the test method. As greater experience is gained from field use of E85 vehicles and further vehicle hardware developments for the use of ethanol content fuels occurs. it is expected that many of these requirements will change.

4.1.1 Vapor pressure is varied for seasonal and climatic changes by providing three vapor pressure classes for fuel ethanol (Ed85-Ed75). The seasonal and geographical distribution for three vapor pressure classes is shown in Table 1 . Class 1 encompasses geographical areas with $6 \mathrm{hr}$ 10th percentile minimum ambient temperature of greater than $5 \mathrm{Deg}$. C (41 Deg. F). Class 2 encompasses geographical areas with $6 \mathrm{hr}$ 10th percentile minimum ambient temperature of greater than $-5 \mathrm{Deg}$. C (23 Deg. F) but less than +5 Deg $C$ ( 41 Deg. F). Class 3 encompasses geographical areas with $6 \mathrm{hr}$ 10th percentile minimum ambient temperature less than or equal to -5 Deg. C (23 Deg. F).

4.1.2 The hydrocarbons blended with the denatured fuel ethanol shall have a maximum boiling point of 225 Deg. C (437 Deg. F) by Test Method D 86, oxidation stability of 240 min minimum by Test Method D 525, and No. 1 maximum copper strip corrosion by Test Method $D$ 130. The hydrocarbons may contain aliphatic ethers as blending components as are customafily used for automotive spark-ignition engine fuel.

4.1.3 The denaturant for the denatured fuel ethanol used in making Fuel Ethanol (Ed85-Ed75) shall meet the requirements of ASTM D 4806 Section 5.0.

4.1.4 Use of unprotected aluminum in fuel Ethanol (Ed85-Ed75) distribution and dispensing equipment will introduce insoluble aluminum compounds into the fuel. causing plugged vehicle fuel filters. Furthermore, this effect can be exaggerated even with protected aluminum by elevated fuel conductivity caused by cantact with nitrile rubber dispensing hose. Therefore, unprotected fuminum and unlined nitrile rubber dispensing hose should be avoided in fuif ethenol (Ed85-Ed75) fuel distribution and dispensing systems".

5. Sampling 
5.1 Sample in accordance with Practice $D$ 4057, except that water displacement (10.3.1.8 of Practice D 4057) shall not be used.

5.2 Where practical, fuel ethanol (Ed85-Ed75) should be sampled in glass containers. If samples must be collected in metal containers, do not use soldered containers. This is because the soldering flux residues in the containers and lead in the solder car. contaminate the sample. Plastic containers should be avoided.

5.3 A minimum sample size of about 1 L ( 1 U.S. at) is recommended.

\section{Test Methods}

6.1 Determine the requirements enumerated in this specification in accordance with the following test methods:

Note 2. The appropriateness of ASTM test methods cited has not been demonstrated for use with fuel ethanol (Ed85-Ed75). In addition, the test method outlined in the Annex $A 1$ is in the developmental stage and lacks precision and bias determinations.

6.1.1 Ethanol- Test Method D 5501

6.1.2 Hydrocarbon/aliphatic ether blend content- Use Test method D5501 to determine other aicohols, methyl tertiary-butyl ether (MTBE). and other ethers. Determine water by the Karl Fiseher test method (see 6.1.10). Subtract the concentration of alcohols and water from 100 to get the percent hydrocarbon/aliphatic ether.

6.1.3 Vapor Pressure - Test Method D 4953, D 5190, or D 5191.

6.1.4 Acidity- Test Method D 1613.

6.1.5 Gum Content, solvent washed and unwashed- Test Method D 381.

6.1.6 Total Chlorine as Chloride- Test Method D 4929, Method B.

6.1.7 Inorganic Chloride- Test Methods D 512 or D 2988. An alternate method for inorganic chloride is found in Annex Al.

6.1.8 Lead- Test Method D 5059. With Test Method D 5059, prepare the calibration standards using ethanol (reagent grade) as the solvent to prevent errors caused by large differences in carbon-hydrogen ratios.

6.1.9 Phosphorus- Test Method D 3231.

6.1.10 Water- Test Method E 203.

6.1.11 Copper- Modifieation of Test Method D 1688 as outlined in D 4806.

6.1.12 Sulfur- Test Methods D 1266, D 2622, D 3120, or D5453. With Test Method D 2622. prepare the calibration standards using ethanol (reagent grade) as the solvent to prevent errors caused by large differences in carbon-hydrogen ratios.

\section{Keywords}

7.1 acidity; alcohol; automotive spark-ignition engine fuel; chloride; copper corrosion; ether; gum content, solvent washed; fuel ethanol (Ed85-Ed75) for automotive spark-ignition engines; hydrocarbon; inorganic chloride; lead; MTBE; oxidation stability; oxygenates; phosphorus; sulfur; total chlorine; vapor pressure; volatility: water. 
Footnotes.

(1) This specification is under the jurisdiction of Committee D-2 on Petroleum Products and Lubricants and is the direct responsibility of Subcommittee D02.A on Gasoline and Oxygenated Fuels.

(2) Reference to the following documents is to be the latest issue unless otherwise specified.

(3) Annual Book of ASTM Standards, Vol 05.01.

(4) Annual Book of ASTM Standards, Vol 11.01.

(5) Annual Book of ASTM Standards, Vol 06.03.

(6) Annual Book of ASTM Standards, Vol 05.02

(7) Annual Book of ASTM Standards, Vol 15.05

(8) Annual Book of ASTM Standards, Vol 05.03.

(9) American Automobile Manufacturers Association, "Fuel Methanol Compatibility Standards and Dispensing Equipment List for M85 Fueled Vehicles", October, 1994.

DOC\# DRAFT 11 


\begin{tabular}{|c|c|c|c|c|c|c|c|c|c|c|c|c|}
\hline \multicolumn{13}{|c|}{ 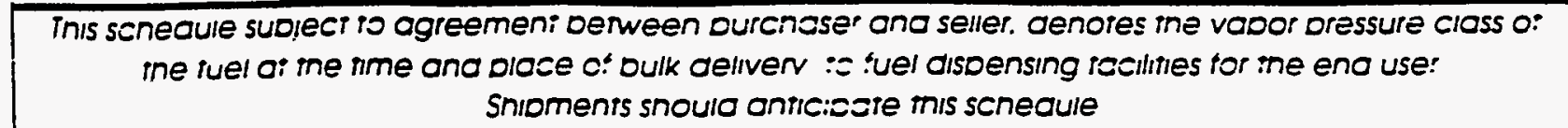 } \\
\hline Store & Jon & Feo & Ma: & $A D r$ & $\mathrm{Nar}$ & June & juIV & Aus & Sec & $0=$ & Nov & Des \\
\hline \multirow{2}{*}{\multicolumn{13}{|c|}{$\begin{array}{l}\text { Aladame } \\
\text { Alasko }\end{array}$}} \\
\hline & & & & & & & & & & & & \\
\hline Souinem Region & 3 & 3 & 3 & 3 & $3 / 2$ & $2 / 1$ & 1 & $1 / 2$ & $2 / 3$ & 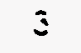 & $\Xi$ & 3 \\
\hline $\begin{array}{l}\text { Soum Maniano } \\
\text { Arizono }\end{array}$ & 3 & \multicolumn{10}{|c|}{ Arizono } & 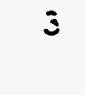 \\
\hline Nof 34 deg Latifuae & 3 & $\Xi$ & 3 & $3 / 2$ & 2 & $2 / 1$ & 1 & 1 & $1 / 2$ & $2 / 3$ & $\Xi$ & 3 \\
\hline S o: 34 aeg Latiruae & 2 & 2 & 2 & $2 / 1$ & $\vdots$ & 1 & 1 & $\mathbf{i}$ & 1 & $: / 2$ & 2 & 2 \\
\hline \multicolumn{11}{|l|}{ Calıtomia (1) } & $2 / 3$ & 3 \\
\hline Nom Coos: & $?$ & 2 & 2 & 2 & 2 & $2 / 1$ & 1 & $r$ & $\mathbf{i}$ & $1 / 2$ & 2 & 2 \\
\hline Soutr. Coas" & $3 / 2$ & 2 & 2 & 2 & $2 / 1$ & 1 & 1 & 1 & 1 & $1 / 2$ & $2 / 3$ & 3 \\
\hline Souineasi & 3 & $3 / 2$ & 2 & 2 & $2 ! !$ & 1 & $i$ & 1 & $1 / 2$ & 2 & $2 / 3$ & 3 \\
\hline !neric & 2 & 2 & 2 & 2 & 2 & $2 / 1$ & 1 & $\mathbf{i}$ & 1 & $1 / 2$ & 2 & 2 \\
\hline \multicolumn{13}{|l|}{ ニン.ン:ลระ } \\
\hline | $\equiv z^{\prime}$ los geg :ongiruse & $\vdots$ & 3 & 3 & $3 / 2$ & 2 & $2 / 1$ & 1 & i & $1 / 2$ & $2 / 3$ & $j$ & 3 \\
\hline 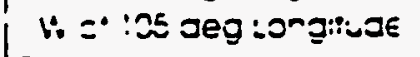 & $\Xi$ & $j$ & 3 & $i$ & $3 / 2$ & 2 & $2 / 1$ & $1 / 2$ & $2 / 3$ & 3 & 3 & 3 \\
\hline 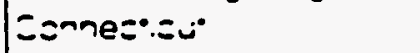 & 3 & 3 & 3 & $3 / 2$ & 2 & $2 / 1$ & 1 & 1 & $1 / 2$ & 2 & $2 / 3$ & 3 \\
\hline De!onare & 3 & 3 & $3 / 2$ & 2 & $2 / 1$ & 1 & 1 & 1 & $1 / 2$ & 2 & $2 / 3$ & 3 \\
\hline $\begin{array}{l}\text { Dismer ot Columbio } \\
\text { :orico }\end{array}$ & 3 & 3 & $3 / 2$ & 2 & $2 / 1$ & & 1 & 1 & $1 / 2$ & 2 & $2 / 3$ & 3 \\
\hline N c: 29 aeg Lamrude & 2 & 2 & .2 & $2 / 1$ & ; & 1 & 1 & 1 & 1 & $1 / 2$ & 2 & 2 \\
\hline Sこ' 28 aeg solituce & 2 & $2 / 1$ & 1 & 1 & $i$ & 1 & 1 & 1. & 1 & 1 & $1 / 2$ & 2 \\
\hline Seorais & 3 & $3 / 2$ & 2 & $2 / 1$ & ' & 1 & 1 & 1 & 1 & $1 / 2$ & 2 & $2 / 3$ \\
\hline - & $:$ & $\therefore$ & 1 & $!$ & : & 1 & 1 & 1 & 1 & $!$ & 1 & 1 \\
\hline $\begin{array}{l}\text { an: } \\
\text { anno:s }\end{array}$ & 3 & $\mathfrak{s}$ & $\Xi$ & $3 / 2$ & $z$ & 2 & $2 / 1$ & $1 / 2$ & 2 & $2 / 3$ & 3 & 3 \\
\hline$r=0$ Li seg antuae & 3 & 3 & $\Xi$ & $3 / 2$ & 2 & $2 / r$ & $!$ & 1 & $1 / 2$ & $2 / 3$ & 3 & 3 \\
\hline c こ* « Jeg Loniude & 3 & 3 & $j$ & $3 / 2$ & $27^{\circ}$ & 1 & 1 & 1 & $1 / 2$ & $2 / 3$ & 3 & 3 \\
\hline$x: x=2$ & $\vdots$ & $\mathfrak{z}$ & 3 & $3 / 2$ & $21:$ & $!$ & 1 & 1 & $1 / 2$ & $2 / 3$ & 3 & 3 \\
\hline ow: & 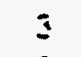 & $\Xi$ & $\Xi$ & $3 / 2$ & 2 & $2 / 1$ & 1 & 1 & $1 / 2$ & $2 / 3$ & $j$ & 3 \\
\hline kansas & 3 & 3 & 3 & $3 / 2$ & $\bar{z}$ & $2 / 1$ & 1 & 1 & $1 / 2$ & $2 / 3$ & 3 & 3 \\
\hline kentrick: & $\Xi$ & $?$ & $3 / 2$ & 2 & $21:$ & $\mathbf{i}$ & 1 & 1 & $1 / 2$ & 2 & $2 / 3$ & 3 \\
\hline 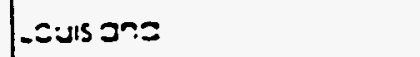 & 2 & $z$ & 2 & $2 / !$ & $\cdot$ & 1 & 1 & 1 & $\mathbf{i}$ & $1 / 2$ & 2 & 2 \\
\hline P:D:ne & $?$ & $\vdots$ & .3 & $3 / 2$ & 2 & $2 / 1$ & 1 & $1 / 2$ & 2 & $2 / 3$ & 3 & 3 \\
\hline Moviane & 3 & j & $3 / 2$ & 2 & $21:$ & 1 & 1 & 1 & $1 / 2$ & 2 & $2 / 3$ & 3 \\
\hline Massacnusets & 3 & 3 & 3 & $3 / 2$ & 2 & $2 / 1$ & 1 & 1 & $1 / 2$ & 2 & $2 / 3$ & 3 \\
\hline \multicolumn{13}{|l|}{ 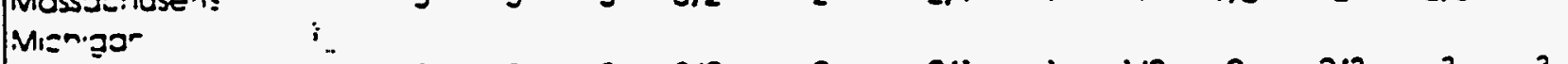 } \\
\hline iower Micnizar & 3 & $\Xi$ & $\Xi$ & $3 / 2$ & 2 & $2 / 1$ & 1 & $1 / 2$ & 2 & $2 / 3$ & 3 & 3 \\
\hline Ucder Misn:zor: & j & 3 & 3 & 3 & $3 / 2$ & $2 / 1$ & 1 & $1 / 2$ & 2 & $2 / 3$ & 3 & 3 \\
\hline Minneso:s & 3 & 3 & 3 & 3 & $3 / 2$ & $2 / !$ & 1 & $1 / 2$ & 2 & $2 / 3$ & 3 & 3 \\
\hline Mississico & 2 & 2 & 2 & $2 / 1$ & : & 1 & 1 & 1 & 1 & $1 / 2$ & 2 & 2 \\
\hline Missour: & 3 & 3 & 3 & $3 / 2$ & $2 / 1$ & 1 & 1 & 1 & $1 / 2$ & $2 / 3$ & 3 & 3 \\
\hline Moniona & 3 & 3 & 3 & 3 & $3 / 2$ & 2 & $2 / 1$ & $1 / 2$ & $2 / 3$ & 3 & 3 & 3 \\
\hline Nedraskc & 3 & 3 & 3 & $3 / 2$ & 2 & $2 / 1$ & 1 & $1 / 2$ & 2 & $2 / 3$ & 3 & 3 \\
\hline \multicolumn{13}{|l|}{ Nevace } \\
\hline No! $3 E$ seg :antuae & 3 & 3 & 3 & $3 / 2$ & 2 & 2 & $2 / 1$ & $1 / 2$ & 2 & $2 / 3$ & 3 & 3 \\
\hline So! 36 aeg lamiuse & 3 & 3 & $3 / 2$ & $\bar{z}$ & $2 / 1$ & 1 & 1 & 1 & $1 / 2$ & 2 & $2 / 3$ & 3 \\
\hline New Hamosnire & 3 & 3 & 3 & $3 / 2$ & 2 & $2 / 1$ & 1 & $1 / 2$ & 2 & $2 / 3$ & 3 & 3 \\
\hline
\end{tabular}




\begin{tabular}{|c|c|c|c|c|c|c|c|c|c|c|c|c|}
\hline New Jersey & 3 & 3 & $3 / 2$ & $i$ & $2 / 1$ & $!$ & 1 & & $i / 2$ & 2 & $2 / 3$ & $\mathfrak{3}$ \\
\hline \multicolumn{13}{|l|}{ New Mexico } \\
\hline$N$ of 34 deg Latruce & 3 & 3 & 3 & 3.2 & 2 & $2 / 1$ & י & r & $i / 2$ & $2 / 3$ & 3 & 3 \\
\hline S o: 34 aeg Lativuae & 3 & 3 & $3 / 2$ & $2 i:$ & $:$ & $\vdots$ & $\cdot$ & & & $: / 2$ & $2 / 3$ & $\vdots$ \\
\hline \multicolumn{13}{|l|}{ New York } \\
\hline$N$ of $\$ 2$ aeg Lativae & 3 & $\hat{3}$ & 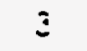 & $3 / 2$ & 2 & $2 / 1$ & $:$ & $\ddot{z}$ & 2 & $2 / 3$ & $j$ & 3 \\
\hline S of :2 deg lomiude & 3 & 3 & 3 & $3 / 2$ & $2 / 1$ & 1 & 1 & & $: / 2$ & 2 & $2 / 3$ & 3 \\
\hline Norn Earolino & 3 & 3 & $3 / 2$ & 2 & $2 / 1$ & $?$ & $!$ & . & $1 / 2$ & $2 / 3$ & 3 & 3 \\
\hline Nortn Jakoio & 3 & 3 & $j$ & 3 & $3 / 2$ & $2 / 1$ & ! & $\because 2$ & 2 & $2 / 3$ & 3 & 3 \\
\hline Onio & 3 & 3 & 3 & $3 / 2$ & $2 / 1$ & 1 & 1 & & $1 / 2$ & $2 / 3$ & 3 & 3 \\
\hline Oklanoma & 3 & 3 & 3 & $3 / 2$ & $2 / 1$ & $\vdots$ & 1 & $\cdot$ & $1 / 2$ & 2 & $2 / 3$ & 3 \\
\hline \multicolumn{13}{|l|}{ Oregon: } \\
\hline E of 122 deg Longituce & 3 & 3 & 3 & $3 / 2$ & 2 & 2 & $2 / 1$ & :iz & 2 & $2 / 3$ & $j$ & 3 \\
\hline \multicolumn{12}{|l|}{ Pennsvivonio } & $2 / 3$ \\
\hline Not $\Delta l$ deg lomude & 3 & 3 & 3 & $3 / 2$ & 2 & $2 / 1$ & 1 & $1 / 2$ & 2 & $2 / 3$ & 3 & 3. \\
\hline So: 4 : deg Latifude & 3 & 3 & 3 & $3 / 2$ & 2 & $2 / 1$ & ? & $\cdot$ & $1 / 2$ & 2 & $2 / 3$ & 3 \\
\hline Rroge isiona & 3 & 3 & 3 & $3 / 2$ & $2 / 1$ & 1 & 1 & • & $1 / 2$ & 2 & $2 / 3$ & $\hat{\jmath}$ \\
\hline Sou:- = s:oling & 2 & 2 & 2 & $2 / 1$ & 1 & 1 & 1 & $\cdot$ & $\mathbf{i}$ & $1 / 2$ & 2 & 2 \\
\hline Sout: Daksta & 3 & 3 & 3 & $3 / 2$ & 2 & $2 / 1$ & $i$ & $i / 2$ & 2 & $2 / 3$ & 3 & 3 \\
\hline \multirow{2}{*}{\multicolumn{4}{|c|}{ :exa: }} & 2 & $2 / 1$ & 1 & 1 & & $1 / 2$ & 2 & $2 / 3$ & 3 \\
\hline & 3 & 3 & $3 / 2$ & 2 & $2 / 1$ & & 1 & - & $1 / 2$ & 2 & $2 / 3$ & 3 \\
\hline Sc: 3: aeg Lamtuce & 2 & 2 & 2 & $2 / 1$ & 1 & 1 & 1 & : & 1 & $1 / 2$ & 2 & 2 \\
\hline |u:sr & 3 & 3 & 3 & $3 / 2$ & 2 & $2 / 1$ & 1 & $:$ & $1 / 2$ & $2 / 3$ & 3 & 3 \\
\hline Vermos:: & 3 & 3 & 3 & $3 / 2$ & 2 & $2 / 1$ & 1 & $1 / 2$ & 2 & $2 / 3$ & 3 & 3 \\
\hline Vi:gin:= & 3 & 3 & $3 / 2$ & 2 & $2 / 1$ & 1 & 1 & - & $1 / 2$ & 2 & $2 / 3$ & 3 \\
\hline \multicolumn{13}{|l|}{ wosning:e- } \\
\hline 三c :az seg Longl:ue & 3 & $\vdots$ & $3 / 2$ & 2 & 2 & $2 / 1$ & 1 & $\cdot$ & $1 / 2$ & $2 / 3$ & 3 & 3 \\
\hline$w \varsigma^{\prime} \cdot z=$ sep songiuar & 3 & $3 / 2$ & 2 & 2 & 2 & $2 / 1$ & 1 & $\cdot$ & $1 / 2$ & 2 & 2 & $2 / 3$ \\
\hline vies" v.9:ר.: & 3 & 3 & 3 & $3 / 2$ & 2 & $2 / 1$ & 1 & $: / 2$ & 2 & $2 / 3$ & 3 & 3 \\
\hline Wisserss:- & 3 & 3 & 3 & $3 / 2$ & 2 & $2 / 1$ & i & $1 / 2$ & 2 & $.2 / 3$ & 3 & 3 \\
\hline Wram:? & 3 & 3 & 3 & 3. & $3 / 2$ & 2 & $2 / 1$ & $i / 2$. & 2 & $2 / 3$ & 3 & 3 \\
\hline
\end{tabular}

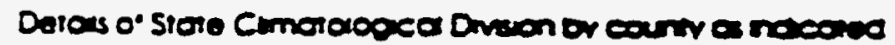

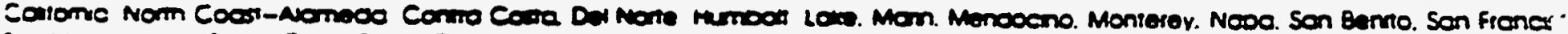
$\operatorname{son}$ Moreo Sorte Clore Somo enz Solono. Sonomo imm

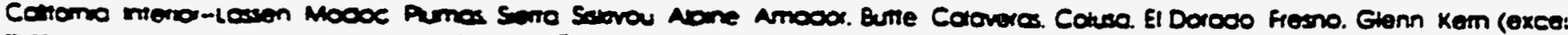

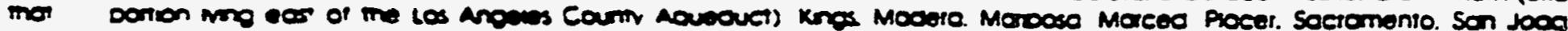
Sneso sionsas

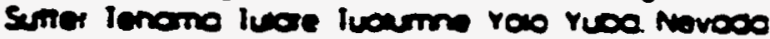

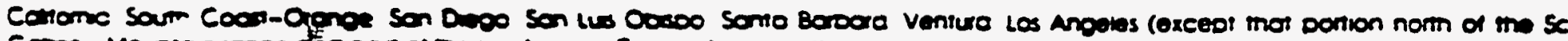

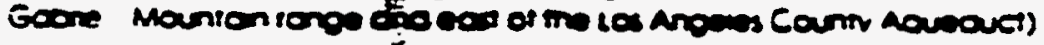
is

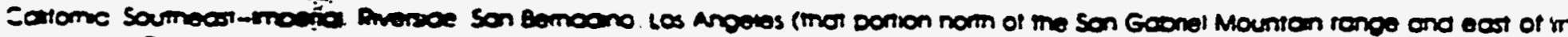

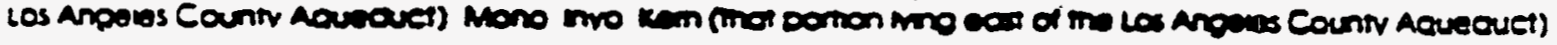




\section{ANNEXES}

(Mandatory Information)

A1. TEST METHOD FOR DETERMINATION OF INORGANIC CHLORIDE IN FUEL ETHANOL (Ed85-Ed75)

\section{A1. 1 Scope}

A1.1.1 This test method covers a procedure to determine the inorganic chloride in fuel ethanol (Ed85-Ed75) in the range of concentrations 0.4 to $2.0 \mathrm{ppm}$.

A1.1.2 The values stated in SI units are to be regarded as the standard.

\section{A1.2 Summary of Test Method.}

A1.2.1 The sample is concentrated, acidified, and treated with silver nitrate. The turbidity is visually compared with standards.

\section{A1.3 Significance and Use}

A1.3.1 Because of the corrosive nature of inorganic chloride to the fuel system of internal combustion engines, a means to measure low levels of inorganic chloride in fuel ethanol (Ed85-Ed75) is required.

\section{A1.4 Apparatus}

A1.4.1 Distillation Apparatus $-500 \mathrm{~mL}$ distillation flask, condenser and $250 \mathrm{~mL}$ graduated cylinder as collector.

Ai. 4.2 Nessler Tubes, $100 \mathrm{~mL}$, matched, tall form.

\section{A1.5 Reagents and Materials}

A1.5.1 Nitric Acid (HNO $)$ Solution . 1 part 15.7M

to 1 port demineralized water. (Warning-See Note A1.1.)

Note-A1. 1: Warning-Corrosive. Health hazard.

A1.5.2 Silver Nitrate Solution, 0.1 M. (Warning -See Note A1.2.J

Note-A1.2: Warning Health Hazard. 
A1.5.3 Ethanol, halide- and sulfide-free by distillation. (Warning-See Note A1.3.)

Note-A1.3: Warning-Flammable. Health hazard.

A1.5.4 Demineralized Water, halirie- and sulfide-free.

\section{A1.5.5 Sodium Chloride $(\mathrm{NaCl})$}

\section{A1.6 Standards}

A1.6.1 Dissolve $0.845 \mathrm{~g}$ of dry sodium chloride ( $\mathrm{NaCl}$ ) in halide- and sulfide-free water and dilute to $1 \mathrm{~L}$ in a volumetric flask. Mix thoroughly and label Solution $A(0.5 \mathrm{mg} \mathrm{Cl} / \mathrm{mL})$.

A1.6.2 Pipet $10 \mathrm{~mL}$ of solution. A into a $1 \mathrm{~L}$ volumetric flask. Dilute to volume with halide- and sulfide-free water. Mix thoroughly and label Solution $8(0.005 \mathrm{mg} \mathrm{Cl} / \mathrm{mL})$.

A1.6.3 In matching Nessler tubes, prepare the following standards:

Blank $\quad \begin{array}{lllll}1 & 2 & 3 & 4 & 5\end{array}$

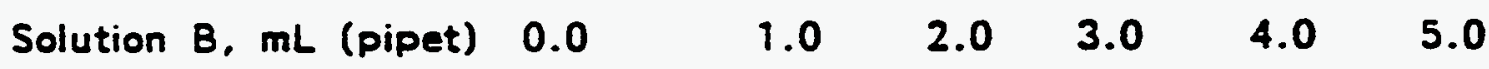

$\begin{array}{lllllll}\text { Ethanol, } \mathrm{mL}(\mathrm{Cl} \text {-free }) & 80 & 80 & 80 & 80 & 80 & 80\end{array}$

A1.6.4 For each standard follow A1.7.4 to A1.7.8.

Ai.6.5 The turbidity standards are affected by light and are not stable. Prepare fresh standards (from solution B) for each group of samples.

\section{A1.7 Procedure}

A1.7.1 Clean all glassware with $1 \mathrm{M} \mathrm{HNO}_{3}$, and rinse with demineralized water and halide- and sulfide-free ethanol.

A1.7.2 Measure $320 \mathrm{~mL}$ of sample in a graduated cylinder and put into the distillation flask, add boiling beads. Distill the sample into a graduated cylinder until $240 \mathrm{~mL}$ of the distillate is obtained. Use $4 \mathrm{~mL}$ of the concentratcis residue from the distillation flask as follows.

A1.7.3. Add a $4 \mathrm{~mL}$ sample to a $100 \mathrm{~mL}$ Nessler tube.

A1.7.4 Add $80 \mathrm{~mL}$ of halide- and sulfide-free ethanol to the sample in the Nessler tube. 
A1.7.5 Dilute the contents of all tubes (sample and standards) to the $100 \mathrm{~mL}$ mark with halide- and sulfide-free water.

A1.7.6 Pipet $2 \mathrm{~mL}$ of nitric acid solution (1 part $15.7 \underline{M}$ acid to 1 part demineralized water) into each tube. tube.
A1.7.7
Pipet $1 \mathrm{~mL}$ of
$0.1 \underline{M}$
M silver

A1.7.8 Stopper and mix thoroughly by inverting.

-A1.7.9 Allow the tubes to stand in the dark for $5 \mathrm{~min}$. Visually compare the sample to the standard solutions while looking vertically against a black background. Record the millilitres of standard Solution $B$ that match the sample.

\section{A1.8 Calculation}

(A1.1) Calculate the results as follows:

(A) $(B)(0.001)(1000000) /(320 / 80)(4)(0.789)=\mathrm{ppm} \mathrm{Cl}$

where:

A $\quad=m L$ of Solution B that matched sample.

$B=m g \mathrm{Cl} / \mathrm{mL}$ of Solution $B$.

$0.001=m g$ to $g$.

$320 / 80$ =concentration factor,

$4=\mathrm{mL}$ of sample, and

0.789 = relative density of ethanol at 20 deg $C(68$ Deg F) compared to water at 4 deg C (39 Deg F)

\section{A1.9 Precision and Bias}

A1.9.1 Precision- The precision of this test method for measuring inorganic chloride in fuel ethanol (Ed85-Ed75) is being determined.

A1.9.2 Bias- Since there is no accepted reference material for determining bias for the procedure in this test method for measuring inorganic chloride in fuel ethanol (Ed85-Ed75), bias has not been determined. 


\section{APPENDICES}

(Nonmandatory Information)

\section{SIGNIFICANCE OF SPECIFICATION FOR FUEL ETHANOL (ED85-Ed75)} FOR AUTOMOTIVE .SPARK-IGNITION ENGINES.

\section{$X 1.1$ Ethanol}

X1.1.1 The ethanol content of fuel ethanol (Ed85-Ed75) is a critical parameter as it affects the capability of the fuel metering system of the dedicated Ed85-Ed75 vehicle to establish the proper air/fuel ratio for optimum vehicle operation. This is much less of a concern for multifuel - capable vehicles than for dedicated Ed85-Ed75 vehicles. Ethanol content may also affect the lubricating properties of the fuel, the water tolerance of the fuel and the ability to meet coid and cool area volatility. requirements.

$X 1.1 .2$ The inclusion of impurities, some denaturants, and contaminants, except for the deliberately added hydrocarbons or additives or both, can impact adversely on the properties and performance of fuel ethanol (Ed85-Ed75). as an automotive spark-ignition engine fuel. The quantities of some of these materials are controlled by specified property limits. The limits on water, higher molecular weight alcohols, and methanol, and types of denaturants as well as minimums on the amount of ethanol and hydrocarbons limit, but do not prevent, the presence of trace materials.

\section{$\mathrm{X} 1.2$ Hydrocarbon}

X1.2.1 Hydrocarbons are deliberately added to provide improved cold startability and warm up driveability. The addition of hydrocarbon to fuel ethanol changes its volatility and can affect the flammability of fuel tank vapors.

X1.2.2 This specification does not control the composition of the hydrocarbons added to the denatured fuel ethanol. However the hydrocarbons shall be stable, noncorrosive, and be in the boiling range of automotive spark-ignition engine fuel as specified in D 4814. .

\section{$\times 1.3$ Vapor Pressure}

X1.3.1 $\mathrm{T}$ addition of volatile hydrocarbons is required for adequate cold starifibility. The addition of hydrocarbons which are too volatile can contribute to hot fuel handling problems. Higher vapor pressures are required at colder ambient temperatures while lower volatility fuels are less prone to hot fuel handling problems at higher (summertime) ambient temperatures. Excessive vapor pressure contributes to evaporative 
emissions. Lower and upper limits on vapor pressure for the three volatility classes are used to define the acceptable range of volatile components to ensure adequate vehicle performance.

$: \% 1.4$ Acidity

$\times 1.4 .1$ Very dilute aqueous solutions of organic acids such as acetic acid are highly corrosive to a wide range of metals and alloys. It is therefore necessary to keep such acids at a very low level.

\section{X1.5 Gum Cöntent, Solvent Washed and Unwashed}

X1.5.1 The test for gum content, solvent washed, measures the amount of residue after the evaporation of the fuel and following a heptane wash.

The heptane wash removes the heptane-soluble, nonvolatile material such as additives, carrier oils used with the additives, and diesel fuel. Gum content, unwashed, consists of fuel-insoluble and fuel soluble gum. The fuel-insoluble portion can clog fuel filters. Both can be deposited on surfaces when the fuel evaporates.

X1.5.2 Gum content, solvent washed, can contribute to deposits on the surface of carburetors, fuel injectors, and intake manifolds, ports, valves and valve guides. The impact of gum content, solvent washed, on malfunctions of modern engines which can operate on fuel ethanol (Ed85-Ed75) has not been fully established but is based on limited experienced gained with M85-M70 fuels in field tests and from historic gasoline limits. Performance effects depend on where the deposits form, the presence of other deposit precursors such as airborne debris, blowby and exhaust gas recirculation gases, oxidized engine oil, and the amount of deposit.

X1.5.3 The difference betweer the gum content, unwashed, and gum content, solvent washed. values can be used to assess the presence and amount of nonvolatile material in the fuel. Additional analytical testing is required to determine if the material is additive, carrier oil, diesel fuel, etc.

X1.5.4 The gum content, unwashed, limit is intended to limit high-boiling contaminants, like diesel fuel, that can affect engine performance, yet allow the use of appropriate levels of deposit control additives with carrier oils in fuel ethanol (Ed85-Ed75).

X1.5.5 Béause the precision statements for D 381 were developed using only data ag hydrocarbons, they may not be applicable to fuel ethanol (Ed85-Ed75).

\section{X1.6 Total Chlorine}


$X 1.6 .1$ lonic (inorganic) and organic chlorine are corrosive to many metals, and it is desirable to minimize organic and ionic chlorine compounds in fuel ethanol (Ed85-Ed75).

$\times 1.6 .2$ A total chlorine limit of $2 \mathrm{mg} / \mathrm{kg}$, maximum has been found to be inadequate in protecting some fuel system components. An inorganic chloride limit of $1 \mathrm{mg} / \mathrm{kg}$, maximum, is specified to provide additional protection.

\section{$\times 1.7$ Lead}

X1.7.1 Most vehicles equipped to operate on fuel ethanol (Ed85-Ed75) are equipped with exhaust catalysts that control emissions of aldehydes (formaldehyde and acetaldehyde) as well as regulated emissions. Lead compounds deactivate the catalyst and are therefore limited to trace amounts.

\section{X1.8 Phosphorus}

X1.8.1 Like lead, phosphorus deactivates exhaust catalysts and is limited to trace amounts.

\section{X1.9 Appearance}

X1.9.1 Turbidity, phase separation, or evidence of precipitation normally . indicates contamination.

\section{$\times 1.10$ Water}

$X 1.10 .1$ The solubility of hydrocarbon in fuel ethanol (Ed85-Ed75) and blends with gasoline as may occur in multi-fuel capable vehicles decreases with lowering temperature and increasing water content. Separation of the hydrocarbon from the fuel will adversely affect cold starting and driveability and denaturing. Water may affect the calibration of some types of composition sensors of multi-fuel capable vehicles. Water also reduces the energy content of the fuel and thus adversely affects fuel economy and power. Because some degree of water contamination is practically unavoidable in transport and handling, and because the fuel ethanol (Ed85-Ed75) is miscible with water, the water content of fuel ethanol (Ed85-Ed75) is limited to reduce the potential for problems.

$X 1.11$ Copper

X1.11.1 Copper is a very active catalyst for low-temperature oxidation of hydrocarbons. Experimental work has shown that copper concentrations higher than $0.012 \mathrm{mg} / \mathrm{kg}$ in commercial gasolines may significantly increase the rate of gum formation. 
X1.12 Sulfur

X1.12.1 The limit on sulfur content is included to protect against engine wear, deterioration of engine oil, corrosion of exhaust system parts, and exhaust catalyst deactivation.

jimd 2/28/95

DOC\# DRAFT 8 
Appendix B

SAE J1832 - SAE Recommended Practice for Gasollne Fuel Injector 


\section{FUEL INJECTION PUMPS-HIGH PRESSURE PIPES (TUBING) FOR TESTING-SAE 11418 DEC87}

SAE Standard

Repon of the Engine Commilee approwed Decernber 1987. This report references 1504093.

1. Purpose-This standard specifies the dimensional requirement of 2 range of high pressure pipes for use in the bench iesting and setung of fuel injection pumps.

Only dimensions and requirements affecting the hydraulic characteristic of the pipes are defined. Other requirements. such as the type of end connections and shape of the pipes when bent, are not inciuded. These depend on the connections provided at pump outless and injector inlets, and on the design features of individual pumps and test benches.

2. Deseription-The range of pipes specified enables pump and engine manufacturers to choose suitable pipe sizes for pump delivenes up to $300 \mathrm{~mm}^{9}$ per stroke per cylinder. The particular pipe to be used ahall be identified by the pump manufacturer in the test specifiction for each individual pump type and application.

3. Dimension-The seven standardized sizes of pipes are shown in Table 1. Dimensions are in millimeters.

\section{- 4. General Reguiramente}

41 The pipes may be of ferrous material, usually cold-drawn mild reet, conforming to SAE 5529 MAR83.

42 After end connections are made, any closing-in or reduction in opening of the pipe shall be removed to a depth of at least twice the

\begin{tabular}{|c|c|c|c|c|}
\hline $\ln =$ & 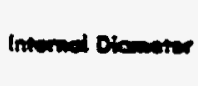 & Extamed & Lengh & 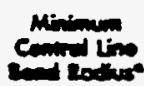 \\
\hline $\begin{array}{l}1 \\
2 \\
3 \\
4 \\
5 \\
6 \\
7\end{array}$ & $\begin{array}{l}2.0 \pm 0.025 \\
2.0 \pm 0.025 \\
3.0 \pm 0.025 \\
3.0=0.025 \\
3.0 \pm 0.025 \\
1.6 \pm 0.025 \\
2.0=0.025\end{array}$ & $\begin{array}{l}0 \\
8 \\
8 \\
6 \\
6 \\
6 \\
6\end{array}$ & $\begin{aligned} 600 & =5 \\
845 & =5 \\
600 & =5 \\
1000 & =5 \\
700 & =5 \\
600 & =5 \\
400 & =5\end{aligned}$ & $\begin{array}{l}16 \\
16 \\
25 \\
25 \\
25 \\
16 \\
16\end{array}$ \\
\hline
\end{tabular}

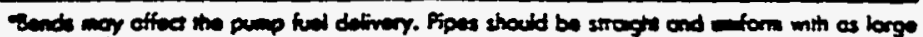
a poustib banding rodit.

length of the deformed end of the pipe. Any closing-in of the ends after extended use shall also be eliminated.

4.3 Pipes shall be cleaned internally after the ends are made and bent in order to remove extraneous matter.

4. During storage, the pipes should be procerted intermally against corrosion and contamination.

4.5 Flow specifications for straight lines are noe applicable to bent line: therefore, straight-line flow specifications are not provided.

\section{GASOLINE FUEL INJECTOR- SAE 11832 NOV89}

\section{SAE Rocommondod Practice}

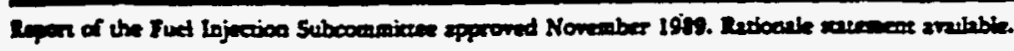

1. Sapa-This SAE Recommended Practice promotes uniforming in the eraluation and qualification tests conducted on fuel injectors used in gavoline engine appliations. Its scope is limited to electronially $2 c$ aned fuel injection devices ured in automotive port or throtele body foed injection sysrems where fuel supply prescure is below $300 \mathrm{kP2}$. If is further restricted to bench type tests. More specifically this document in intended for use 25 a guide to the following:

1.1 Identify and define thowe parameters that are ured to mensure foct injector characteristic or performance. The parmeters inctuded in this document are listed alonf with their recommended syool where approprizie:

Claing Time (CI)

Coil Inductance (1)

Coil Resireance (R)

Dyoumic Fow (Qd)

Dymonic Flow Calculated $\left(Q_{4}\right)$

Dyoumic Flow Rate (Q)

Dymanic Minimum Operating Volnge (DMOV)

Dymanic Ser Poine (PW

Dyonic Set Poine Flow (Q)

External Leakge

Flow-Ofreer (Y)

Inuation Resiunance (IR)

Linear Flow Range (LFR)

Lisearitg Deviation (LD)

Maximum Overload Voluge

Opening Time (OT)

Operating Voltage Range

Period (P)

Pulve Width (PW)

Prevare Drop Ratio (PDR)

Repeareability

Slope $(m)$

Slope Approximated (ma)

Spray Patuem

Seability (5)

Stavic Drop-Orx Current (I/SOOE)

Staic Flow Rate (Do)

Stric Minimum Operating Voltage (SMOV)

Stavic Pulf-In Currene (1/\$ON)

Tire-Office (X)

Working Flow Range (WIE)
12 Exablish test procedures, and recommend tex equipment and methods to meanure and quantify theie parameters.

13 Standardize use of nomenchature specificilt retated to fuel injectors.

2. Ioject Tyes

2.1 Fued Fiow Pach-Injectors may be claswified as top or bottom feed based on the fuel path. Fuel enters ac the top of 2 "top feed" injector (Fig. 12) and nenr the bourom or side of the "bouon feed" (Fig. 1b) injector. Metered fuel exits through the bottom in both type injectors.

A firet filter is typicaily designed as an integral part of the injector at the fuel enternce. This filter is not normally designed to be serviceable. or the onty fuel spreen filtration device. Is min purpon is to prevent initial fuet line and ril contaminants from entering the injector. It also provides contamination procection during testing or servicing of the fuel grtem. An in-line serviceable filcer functions as che primary fuel sprem filtration device. These fileers usually have the apibility of rewoving amaller contaminans than filces used on earbureted systems.

From the inlex filter section, the fuel moves to the foed metering portion of the injector. The meering of fiset is accompinhed by a valve and seat in coajunction with a metering orifice. On engization of the coil megnetic force pulls the valve awry from the sen allowing fuel to pais through the valve/sent and out through the mesering orifice. The Qs of the injector depends on the fuel presioure and the bydraulic losses of the fuel circuit. By dasign, the myjor retriction to flow is in the mecering section. The metering orifice wornlly prevents the largest pres sure drogs however, mom desigos abo rety on a provure drop actoss the valve and seat As the strote or tift of the vilve is varied, the $Q_{3}$ is changed and can be used as a means for the manfocurer to obcain the specified Q. A spring is incorporated to rewre the valve to the cloved pocition when the coil is denergized. Ihis encres that the injector is normilly cioned and fixel an obly flow on exergintion of the coil. The spring also affeces the time required for the ratve to open and clow, which changes the injecos dyamic characteripia. Many de sign, therefore, provide the manufictures with be abtiity to adjust the pretoed of the spring to obcain the dyarmic set poirt flow.

Mout desigas use highly finished metnteo-metai mufaces 20 provide a leak ight sel and minimixe flow shift due to life goting. Metal also help minimize changes in stroke when operated at excreme environonenal zemperanures. Bull/seat, mating conical surfaces and flas surface demigns are in use (Fig. 2).

From the metering section, fuel flows ous through soone type of sprzy pastern generating fenture. The spany is groduced by the aneterng orj- 

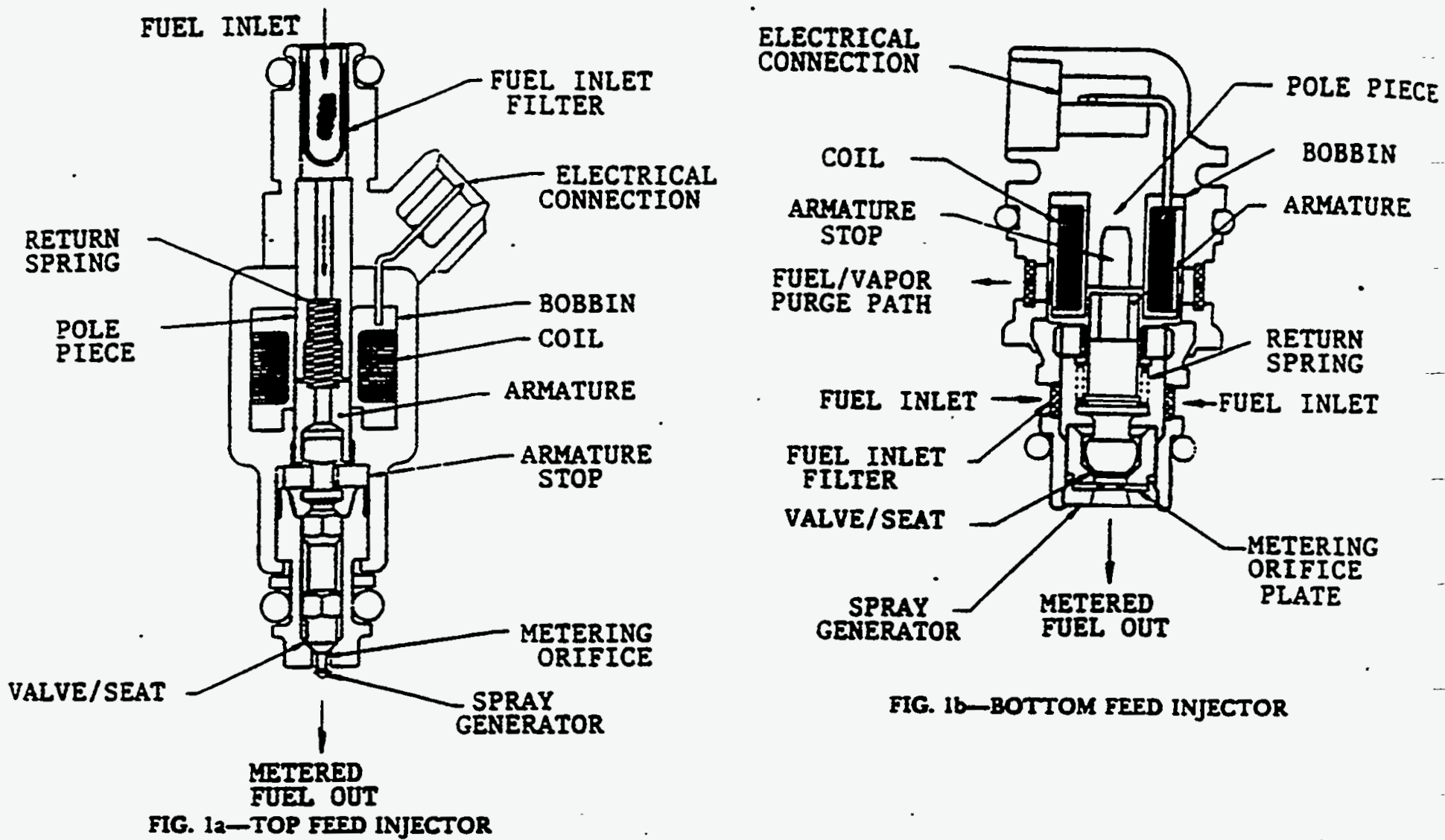

FIG. 1-TYPICAL FUEL INJECTOR DESIGNS
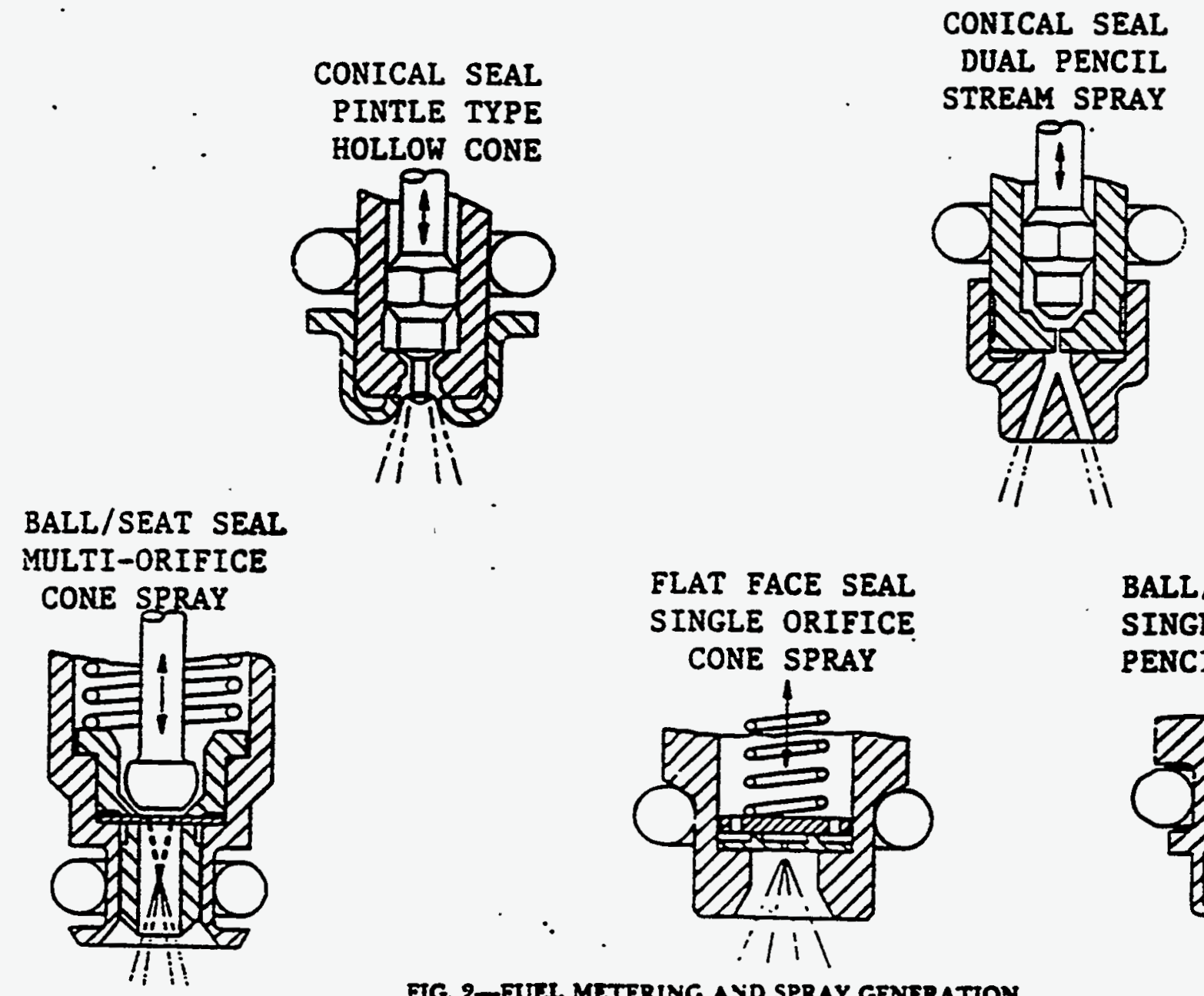

FLAT FACE SEAL SINGLE ORIFICE CONE SPRAY

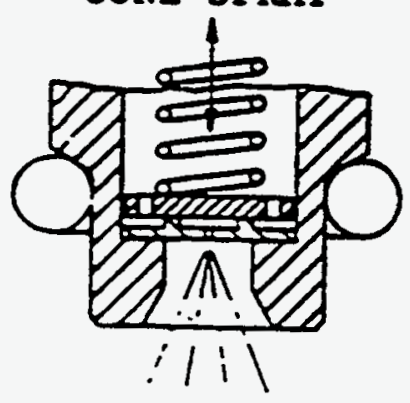

BALL/SEAT SEAL SINGLE ORIFICE PENCIL STREAM

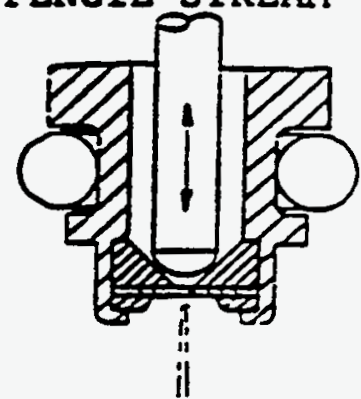


fice or by a separate spray generating part. Injeczors used for throtele body injection generally use multiple orifices to generate a wide angle, bollow cone. The current port fuel injecrion designs are more diversified in sprzy pattern generzaion. Multiple orifice, singie orifice, and pinde styiles exist. These generate patterns ranging from 2 pencil stream to cones of varying angie distribution. With the incroduction of multiple inzake valve per cylinder engine designs, dual stram port fuel injectors are sometimes used. Multiple sprays an target fuel to each inlet valve to promote more uniform air fuel mixture.

Top feed injector designs have the fuel traveling 2xially through the center of the coil and down into the metering area. This design is readily adapeable to PFI, but vapors generated within the injector are not easily purged due to the opposing incoming fuel flow. To minimize vapor generation and provide adequate hot fuel handling, the fuel system presrure is maineained at a telatively high level of 250 to $500 \mathrm{kPa}$.

Botrom feed injectors have been primarily used on cencral fuel injec. tion systems where one or more injectors are located in the throttle body. This design allows packaging of an injector in a fuel metering body such that the injector is centered above the throttle plates. An ad. vanuge of bottom feed injectors is the incorporation of a vapor purge path. Since fuel comes in near the bottom of the injector, the fuel va. pors can rise above the metering area. By providing a direct passage out of the injector, vapors are more easily purged. This vapor purge pastage allows the use of lower fuel pressure $(100 \mathrm{kPa})$ while still maintaining adequate hot fuel handling performance. Although typically used on cenuzl fuel injection applications, there is interex in using the botrom feed design for port applications.

2.2 Mepaetic Circoit - The solenoid asembly of an electromagnetic fuel injector supplies the force to acturate the fuel metering valve. Two commonly used solenoid derigns are the plunger style armature, the most prevalent, and the flat face disk armature. The major compo nents of the solenoid assembly inchude the coil assembly, solenoid body, pole piece, armature, and return spring.

The function of the coil assembly is to produce a magreetic field when energized. The coil consists of a specified number of turas of insulated wire wound around 2 bobbin. The maserial and size of the wire is cho sen to provide a given number of eurns to develog the magnetic force while achieving the required electrial resiarance for the injector driver circuit. Copper is cypically used for low resirennce injecrors and brass for the high resistance injectors. The toeal electrical resirtance of an irjector is essentially equal to that of the coil arsembly, which is 2 function of the resistivity of the wire, length of wire, and the termination of the wire to an electrial connector. Inductance, on the other hand, is 2 funcrion of the number of turns in the coil, materials used for the body, armature, and pole piece, geometric conuruction, air gape, ete. Inductance, therefore, must be mensured on the completed asvembly.

The magnetic field produced by the coil generates firs, which travels in a closed loop around the coil asrembly. It is the function of the components in the magnetic path to carry the fiur efficienth. The solenoid body is the segment of the circuit that carries flux from the pole piece to the armature. The armature is the moving element of the solenoid, which controls the flow of fuel by opening and closing $a$ valve. The pole piece is the nonmoving element that attoncts the armature when the coil is energized. The predetermined clearance besween the pole piece and the armature is called the worting air gap. It is through this air gap that the force of aternction is generated. The working air gap consists of both $a$ fixed and a varible air sap, the huter of which is de. pendent on the pocition or surote of the armature. The fixed air gap prevents contact between the armucure and pole piect to minimize the effect of residual magnetiom. Since contuce between these two pars would result in longer closing times, a stop or specer made from noomagnetic material is used to enaure that a fixed clearnoce is maincained when the valve is fully opened. The magretic force of amsection is max imporant in the working air gap; consequenty the magnetic properties of the materials used and the geomerry of the pars are critial to the performance of the deriga. The remaining parts of the magpetic circuit have a lesser effect on the cocal reluetance and response of the solesoid.

The major difference between the two solenoid derigns shown in Fif. 3 is the peth of the flux into the armarure from the solenoid boty. In the plunger desigm, redial and working air grps ase used. The radial gap is necessary to permit the armature to move axially relacive to the nonmoving componenes of the solenoid asuembly. The working air gap 2000 mmodares the motion of the armanure assembly. In the flat fice disk design, an additional working air gap is required with no radial air $84 p$ between the armature and solenoid body.

23 Cold Start Injector-The cold seart injector is a simplified version of an electromagnetic top feed fuet injector used 20 provide additional fuel during crank at cold ambients. It is uvilized primarity on PFI syrems and is locared in the isles air parage to distribute fuel to all $\mathrm{cy}$ inders. It is normally energized by a bimeeallic switch that provides battery voltage to the injector coil independeat of the electronic control module or injector driver. Dymamic performance is not critial since it is operated only fully "on" or "off". $Q$, atomiation of the fuel, and minimum operating voluge are the imporent criteria.

3. Stendard Test Conditions-Unless orherwise specified, the following test conditions are implied:

3.1 Tea Fluid-Fuel injecrors are designed to spray gasoline, and mok development and testing involves verification of injector performance with that fuel. Gasoline, however. is volatile and variable- in physical properties. A less volatile hydroesbon liquid (normal Hepane) with known physical properries and 2 viscosity and density near gasoline is, therefore, recommended for messurement of injector per. formance charzereristica diecussed in Section 4. It is recognized that no one test fluid is ideal and will dupliate the performance of multihydroarbon fuels found in the field o-heppane was selected as the best compromise on the basis of (1) wortdwide availability. (2) seability if reused, and (3) fluid properties close to that of gasoline. Tests thas are more application-related or conducted for quality control, durabilizy, ete., may be performed with fluids specified by the user.

n-Hepeane is one of the two common pure hydrocarbons used to de fine the octane number sale. and is stocked in all petroleur refinery control and analyrial laboratories worldwide to known levels of purity and consistency. It spras with gesoline-like qualities through the known fuel injector derigns, and yields excellent reproducibility of spray form and how rites. n-Hepeane is not gasoline, however, and How in the mox common injector dexign of 1987 at about 3 to $4 \%$ lower rate than Iodolene, the U.S. EPA emission test gzeoline (see T2ble 1). For different injector derigns, other values of this gasoline to nHepeane difference will be found.

The moce significant advannge of n-Hepeane over gasoline is reuse. bility. It is a pure hydrocarbon compound and noe a mixture of natural. ly oceurring compounds, as in gasoline. Repeated flow testing, resulting in parrial evaporation of the reat fluid, does not change the flow properties of the remaining fluid. Thus, repented how mesuremens are more consistent. When corretarion wort with peoline is arried out, the gasoline should be tested "once-through". the injector. and fresh gatioline used for replicate terses. In this way, property change in the gesoline due to partial evaporation will be avoided.

Both gesoline and n-Hepenne are lighe, volatile liquids, and have flash points well below normul room temperature. Vapor from boch liquids, therefore, poses a fire hanard that must be continuously controlled in the laboratory areas.

Factorf floor eavironments seldom peronit routine use of flammable liquids above their flash poines. Manufacture of fuel injectors generally involves a flow measurement of the completed (or partially completed) injector, and a bevier-ehan-greoline liquid is usually chowen for this purpoce, so thes the flash poins of the liquid is higher than the factory working ares tempersture. Ose such liquid is a typical medium petroleum divillate usually alled "minesl spirits" in the USA, which has a fash point over $43^{\circ} \mathrm{C}$. Such liquids require a laboratory-20-factory floor alibration step in which 2 flow rate on the kese fluid corresponding to the dexired gasoline flow rate surt be establiched for each individual injector design and test coodition. No general relationahip is appropriate, or possible, from this document. Middle distillutes for factory floor use are normully procured from coavenient local facilitien near the makers planes and vilid-for-he-butch alibrations are made to determine and maintain productios quality of the finished injectors. Physical

FLAT DISX DESTCM PLUMEER OESICX

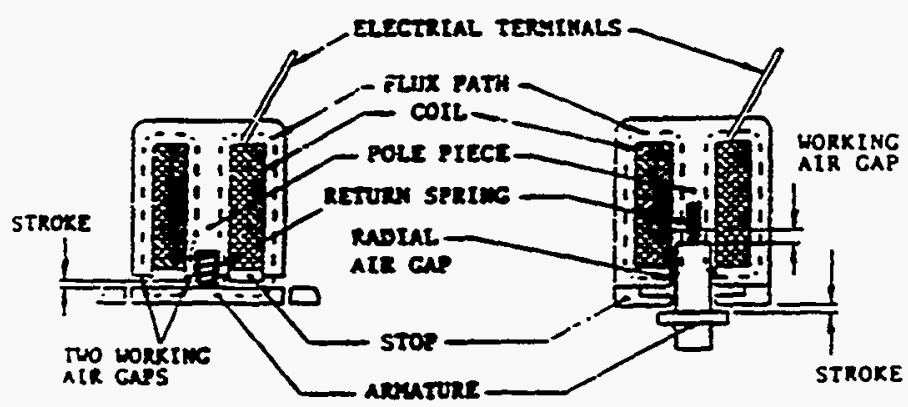

FIG. 3-MAGNETIC CIRCUIT 


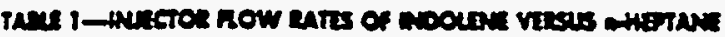

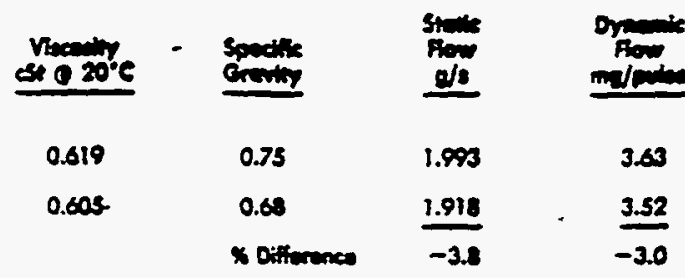

property specifications for n-Hepane, Indolene, and mineral spirits are given in Table 2.

3.2 Floid Tempereure-Should be measured at the injector inlet and stabilized at $20^{\circ} \mathrm{C} \pm 1.0$ (Reference 6.1 ).

3.3 Injecor Temperature-Should be stabilized at room temperzrure $22^{\circ} \mathrm{C} \pm 3$ prior to test.

3.4 Pn deterwined by the appliation and held to within $\pm 0.10 \mathrm{kPz}$ of this vatue throughout the test. It should be specified in (KPa) units and measured at the injector inlet (Reference 6.1).

3.5 Pestod (P) - The time elaped between the beginning of one injection puive to the beginning of the nexs pulse shall be $10 \mathrm{~ms} /$ pulse \pm 0.001 for both port and throttle body injection applientions whether the fuel delivery method is simulaneous single or double fire, sequeniil. exe.

3.6 File Widh (PW)-The increment of time (ms) that the injecoors are commanded 20 deliver fuel shall be determined by the type of test being conducted and held within $\pm 0.001 \mathrm{~ms}$.

3.7 Injector Driver-Determined by application and of instrument 4.1 for typical driver types). Voltage supplied to the driver shall be $14.0 \vee D C \pm 0.03$.

3s Polerity-Maintained consant throughout all texing and same as that used in the appliction.

ss Tw Apparamo-The type of flow fixture used will vary depeoding on the parcicular injector parmeter being evaluated (Refer. exce Section 6).

3.9.1 Isstaukarts-Sabilized per manufacturess' recommendations.

3.9.2 INyector Posrrion-The injector should be mounted vertially eroept when rested as an integral part of a fuel rail aseimbly.

3.9.3 Puecondmonne-Punge injectors and text apparnaus with tess fluid to remove all air, vapors, and shipping fluids. Flow injectors for 10000 puises at $5.0 \mathrm{~ms}$ PW and $10 \mathrm{~ms}$ P. Discard purge fluid.

3.9.4 Flow Mensuneunt - Flow rate may be mensured by either volume or mase flow with the latter being the prefersed method. Data should be reporred in mass flow unis ( $\mathrm{d} / \mathrm{s}$ or mo/pulse).

4. Batic Chereteristies and Deglolitions

4.1 Inactional Parancers-The following are panmeters used in describing and/or measuring the basic functional characteristics of the injecror.

4.1.1 Parsos (P)-The reciprocal of the Erequescy of injection; that is. the time elapred between the beginning of one injection to the be ginning of the next injection, expressed in units of (ms/pulse).

4.1.2 PLISI WidTH (PW)-IDerement of time that the injectors are commanded to deliver fod for a single injection event (mo).

4.1.3 STAt7c Flow RATz (O.) - The rne of fuel delivered $(\mathrm{g} / \mathrm{s})$ by an injecror when energized in the fally coened pocition. It is the maximum flow rate of the injector and can be uned to approximate the slope $\left(\mathrm{m}_{\mathrm{a}}\right)$ of the injector flow curve (Reference 4.1.11)

4.1.4 Drumac Frow (QN)-The mesared fuel delivered per pulse of the injector (mo/pulse) when energized at a specified puive width: that is, the actual quancisy of fuel delivered during dymonic operation.

4.1.5 Drsinac Frow RaTx (o-The fuel delivered per unis of time when energized at 2 specified PW and P. This term is used to indicate the flow rate of the injector in units of $(C / s)$.

$$
Q=0, / 2
$$

4.1.6 Drume Flow Calcoratro ( $\left.Q_{d}\right)$ - The calculated fuel deliv. ery per pulse of the injectos at a given pulve width besed on the calcu bued (linenrized) flow curve specified in my/pulse.

$$
Q_{k}=m(P W)-Y=m(P W-X)
$$

4.1.7 Drsnunc Str Ponst (PW ) - The palse wideh specified in (msh 2t which a specified fuel delivery is set during manufacoure of the injec. tor. It escablishes Qsp, the dynamic performance and offset characrerns tics of the injector. It represeats a Qt point of pulse width at which the flow variation of a population of injectors is minimized.
4.1.8 Dnwanc Set Point Flow (Qjp) - The measured fuel deliver per pulse of the injecror in $\mathrm{mg} /$ pulse when eocrgized at the dyn ser point. This flow is used for incoming inopecion and quality cor

4.1.9 Lineaktr Deviation (LD)- Ideall, the flow from an inject should be linear and directly proporional to pulse width over the $f$ flow range of the injector. This is not the acovil cose. for signifiean viation from linearity occurs at the extremities of the flow curve (. 4. and 5). In order to measure the deviaion from linearity, a. squares regression analysis is performed on five intermediate flc points $2 t 3,4,5,6$, and $7 \mathrm{~ms} P W$ with 2 period of $10 \mathrm{~ms} /$ pulse. $Q d$ ar PW are, respectively, the dependent and independent variables. resulting curve is referred to as the linearized flow curve. Devia

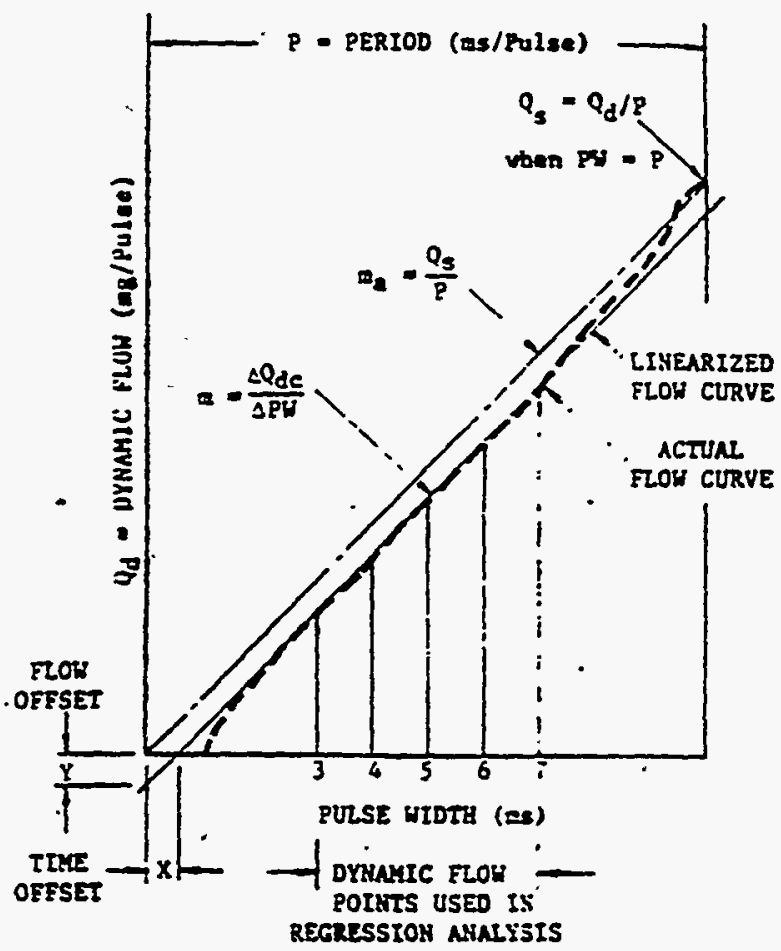

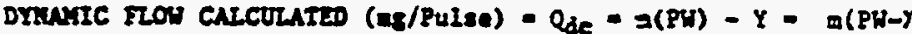
Drunat FIOA RAFE $(8 / 8)=Q=Q_{d} / P$

\section{FG. 4-CHARACTERISTIC INJECTOR FLOW CURVE}

from linearisy is then defined as the percear difference between the

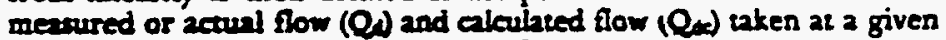
pulve width divided by the calculated how.

$$
\text { LD } \frac{Q_{1}-Q_{1}}{Q^{2}} \times 100-\%
$$

4.1.10 Swor $(m)$-The change in Qe per unit of pulse width based on the claculated linear regresion flow curre (mg/pulse/ms).

$$
\text { m } \frac{\Delta Q_{k}}{\Delta P W}
$$

4.1.11 Swor Aproxputro (mu- An approximation of the injector flow curve in using the $Q$ expresued in uniss of (mg/pulse) when the $P$ and $P W$ are equil (ree Fig. 4 ).

$$
m_{0}=\mathbf{Q} / \mathbf{R}
$$

When: $Q-(m g / p u l c e)$ and $P$ - PW (mis)

4.1.12 Tinnorrst (x)-The dippircenent of the calculated lineat regresuion flow curve from the origin along the abcisse or puise width axes (Fig. 4).

4.1.13 Fiow-orsst (Y)-The dipplacemese of the calculated linear regrescion flow curve from the origin aloug the ordinate or $Q_{\downarrow}$ axis (Fie. 4). 


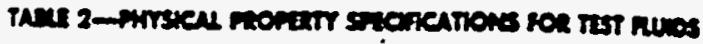

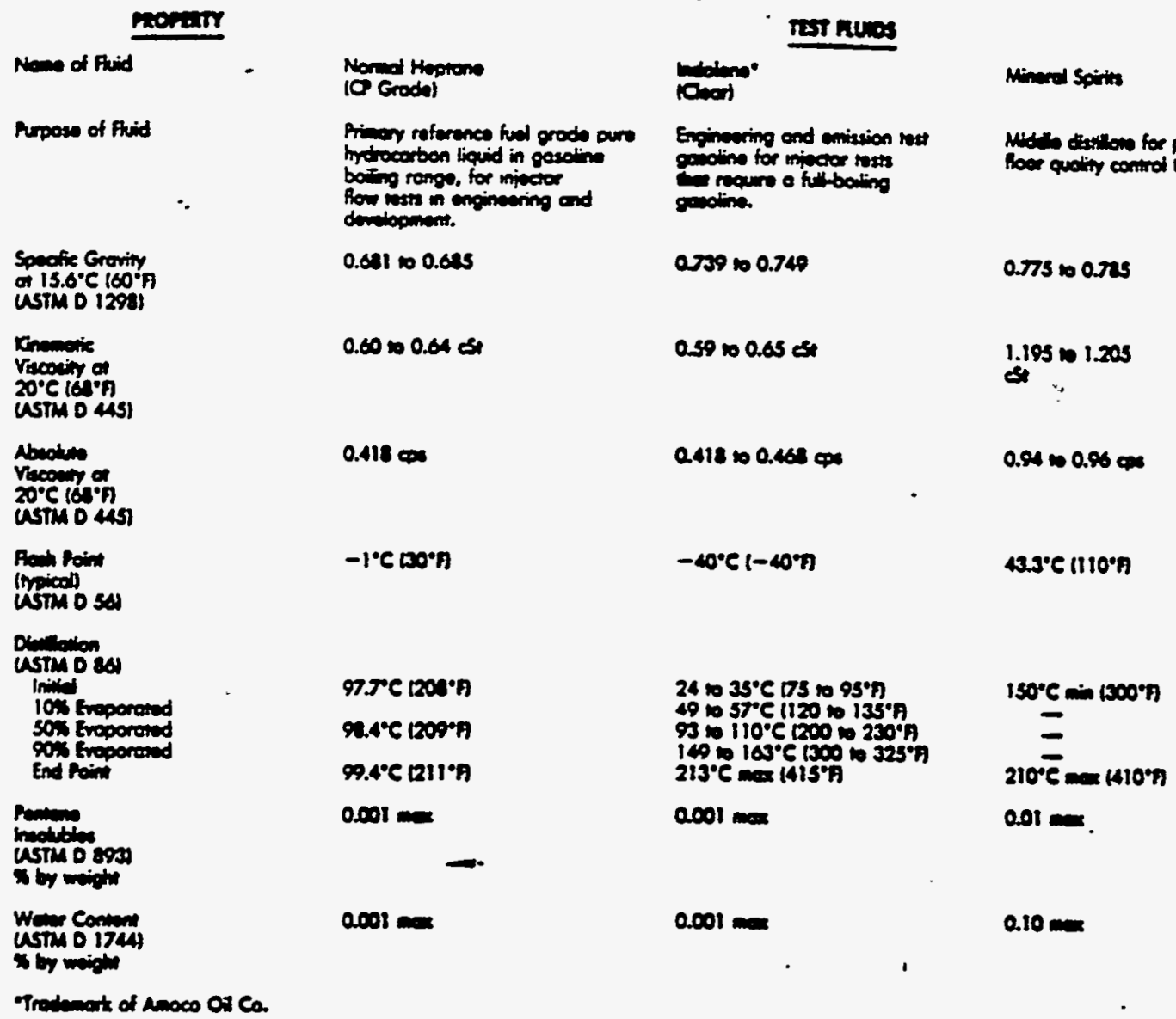

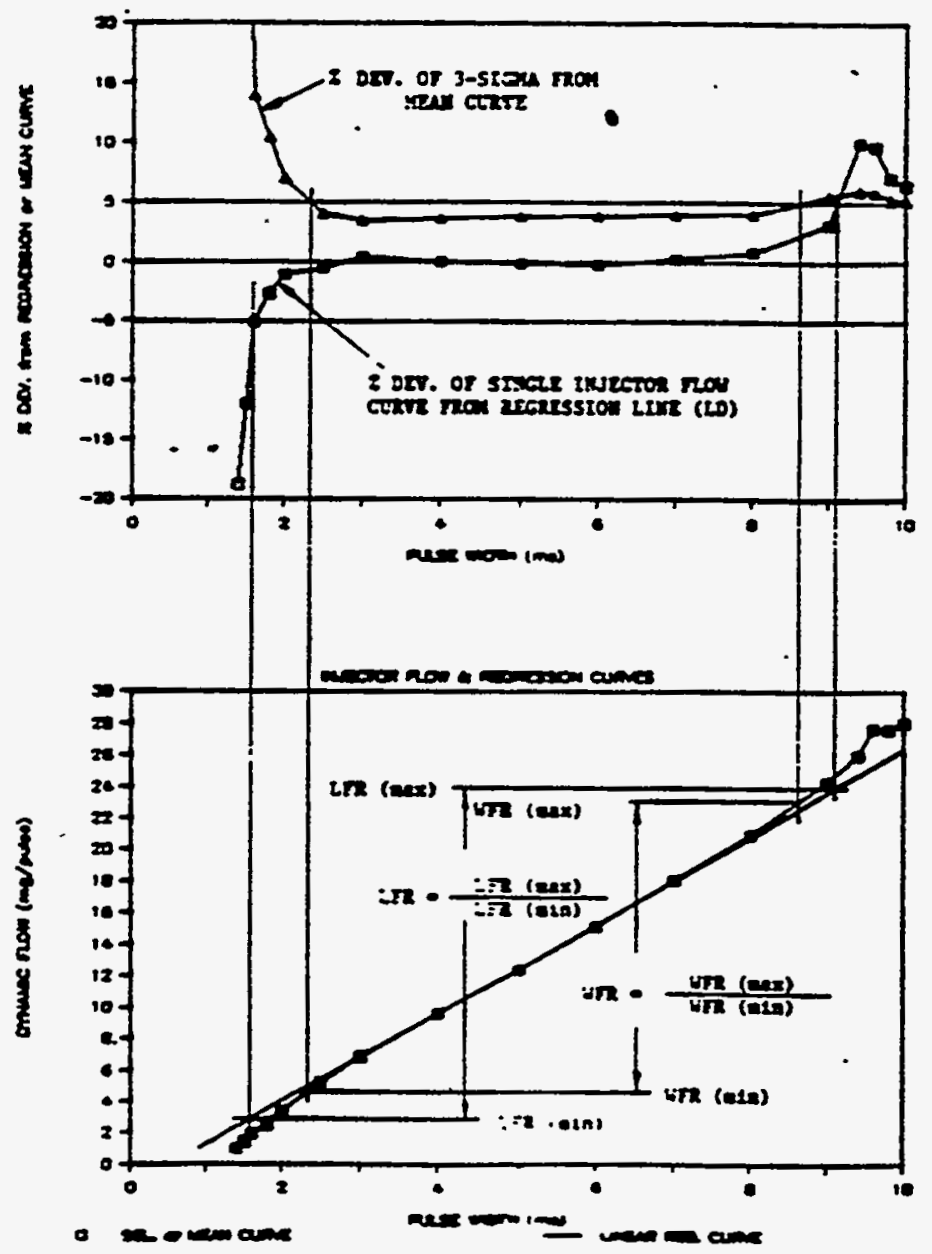

FG. 5-CALCLLATION OF FLOW RANGE 
4.1.14 FLOW RANGE (LFR and WFR)-One of the more imporant characeristic of an injector is the usable minimum and maximum fuel flow. Flow range, specified as 2 ratio of the maximum to minimum dynamic flows, is used 25 measure of this capability. Two methods are used for calculating the ratio: LFR and WFR.

4.1.14.1 Lirear Flo Range (LFR)-A number based on the linear. ized tlow curve of a single injector. It is used to compare the linear range between injectors of different design or manufacture. The number is defined as the maximum linearized how point LFR (max) divided by the minimum linesizized llow point LFR (min) $2 t$ their respective pulse widths where the measured flows deviate $\pm 5.0 \%$ from the linear. ized flow curve (see Fig. 5).

$$
\operatorname{LFR}=\frac{\operatorname{LFR}(\min 2 x)}{\operatorname{LFR}(\min )}
$$

4.1.14.2 Working Flow Range (WFR)-A number baced on the mean flow curve of a population (24 minimum) of injectors representative of 2 normal production discribution. The application engineer is intereseed in this ratio, since it provides 2 relative measure of production injes. tor-co-injector variability, that is, the flow range where a population of injectors will be within a specified tolerance. It is defined as the maximum working flow point WFR (max) divided by the minimum working flow point WFR (min) where all injectars are within $15.0 \%$ of the mean flow curve at three standard deviations (see Fig. 5).

$$
W F R=\frac{W F R(\max )}{\text { WFR (min) }}
$$

4.1.15 Rerzitauturx-Ideally a meamire of the pulserto-pulse flow rate variation of the injector. It is an important element from the standpoint of engine control for emiscions. The equipment required to zecurately determine the mass flow for one injection pulse is expensive and resolution is limited. The following procedure is, therefore, recommended as a compromice:

The injector is tested at standard conditions at two points on the flow curve: (1) the $Q_{\text {n. }}$ and (2) the 2.5 ms $Q$ point. $A$ minimum of 30 tests is conducted at each tert point. Repentability, given in perceat, is then defined as:

$$
\begin{aligned}
& \text { Static Repenability }=\frac{\left.Q_{\text {(max }}\right)-Q_{1} \text { (min) }}{Q_{1}(2 v)} \times 100=\% \\
& \text { Dynamic Repeambilizy }=\frac{Q_{1}(\max )-Q_{1}(\min )}{Q_{1}\left(a_{1}\right)} \times 100-9
\end{aligned}
$$

4.1.16 STMutury (S)-S is a measure of the variation in injector OT and CT and is an indirec mensure of pulsetopule performance or re pearability. It is determined by using a sronge cuclloucope and obrerv. ing the trace representing the OT and CT per 4.1.17. A timer can also be used to directly mearure the elaped time of the opening and cloving events by triggering it at the initivion of-the injector control pulse. Resolution should be adjusted wch that variations of 10 is an be dis. cerned. Operiag and clocing times should be recorded for a minimum of 1000 consecurive pubs and the range stated in microseconds. Fig. 6 shows a typial measurement of docing time insobilis.

4.1.17 Orzinc avp Crome Tna - the opening bime (OT) of an injector is a measure of the time required for the injector armature to first reach its fully opered pocitioned after initinion of the driver cir. cuit pulse inpuc. Closing time (CI) is the tione required for the injector 2rmature to first reach its fully cloned porition after the rermination of the driver circuit pulse input. Boch Or and CT are recosded in (ms). They provide a relative indiation of the combined mechanical and coil response time. The toeal time to open and cloce the injector orifice also provides 2 relative measure of the unble pulse width ranige of the injec. tor. Fig. 7a shom 2 typical trace when using a pealthold drives with an injector of low R. Fig. $7 b$ show a typical asce whes uring a savurated driver and an injector with high $\boldsymbol{R}$.

The preferred method of measuring the opening/clocing time interval is by the use of a precirion accelerometer mounted within $2.5 \mathrm{~cm}$ of the injector body and a suirable time measuring instrument. The accelerometer may be mounted on either the injector body or on the fixture as shown in Fig. 8.

Alternate methods, though les accurare, inchude the ure of a dynam. ie pressure crasducer for both opening and clowing, the inflection in the current tree for opening only, and the inflection in the voleage tree for closing only (Referesce Figa. 6 and 7 .

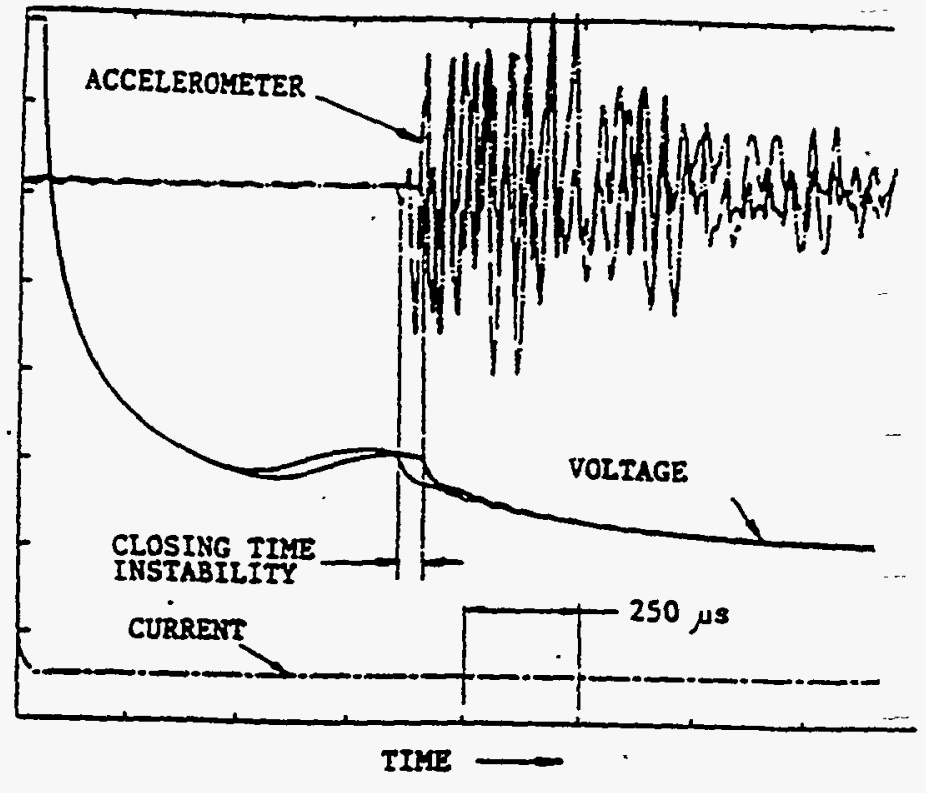

FIG. 6-MEASUREMENT OF CLOSING TIME INSTABILUT

4.1.18 Con Rastance (R)-Mensurement of $R$ permits the inject user 10 determine the current requirement for a given system volugte. Preseaty, injector solenoid desigus consict of either high or low resis unce coils. The high reristance derign is typially 12 to $16 \Omega$ and us . with a saurated circuit driver. The driver turns battery voluge on at off allowing currens to be controlled by the $R$. The low resistance $d$. siga is typically 1 to $4 \Omega$ and uses a curreat limiting driver. This sysem allows a peaik current for repid opening response followed by a lower current level, cilled the hold eurrent, for the remainder of the cor mond pulse.

The recommended mearurement technique is by direct current with the injector at a uniform temperature of $20^{\circ} \mathrm{C} \pm 1$. The four-wire method is preferred. A two-wire measurement is acceppable if measul ing leads are zeroed. The unit of meavirement is to be the ohm wir a menured aceures of $\pm 0.01 \Omega$.

4.1.19 Corl Inguctaven (L)-The inductance of an electromagnetic solesoid is a function of the number of turns in the solenoid coil and the permeasee of the magnecic circuil. Induconnce is an indirect mea sure of the macerial properties and geometry of the llux path. Its valus is, eberefore, meaningfill as a production control parmeter.

Inductance, sogether with $R$, provides the time conseant when the votage is known and cas be used in predicting the initial current ris profie.

The recommended method of measurement is with the injector in the dosed or unenergized potioion using a Whentsone Bridge or equivalent connected in a four-wire series mode. The sandard rest frequen$\sigma$ und is $1.0 \mathrm{kfls}+0.5 \%$ with a pocential of $1.0 \mathrm{~V}$ rms. The unit of mesoremem is the milliheary with a reported resolution of $=0.01$ min.

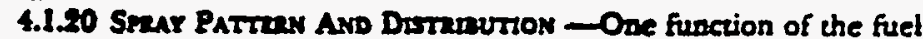
injector vive is to breat up the fuet into fine droplets. The engrise's combursion proces requires vaporization of the gasoline for proper comburion. Fine droplets increase the surfice aren to volume ravo of the gasoline, which reduces che cime for the gasoline to vaporue.

The control of ebe epsey pattern chancteriteic is imporant for all types of fuel injection syrems. The spay parters targets fuel to optiaire unaportation and raporianion. The redill and segmental fuel distriburions are the charecteristices apecified to define the spray patrern.

Multipoint fuel injector decigus an have single or multiple sprays with vaying cone anfles. Sprays leas than $8 \mathrm{deg}$ included angle are normalk refersed to as pescil stream. The harger spray cone angles range from 8 to 30 deg inctuded angle. The spray cone fuel distribution an be bollow with the mujority of the fuel in the outer cone surface or solid with a firity uniform direriburion of fuel within the cone angle.

Throcte body fuel injectors spionily bave a hollow spray cone partera raging from 40 to 60 det inchuded angie. The spray cone angie is specified to target the fuet with respect to the throttle plate. 


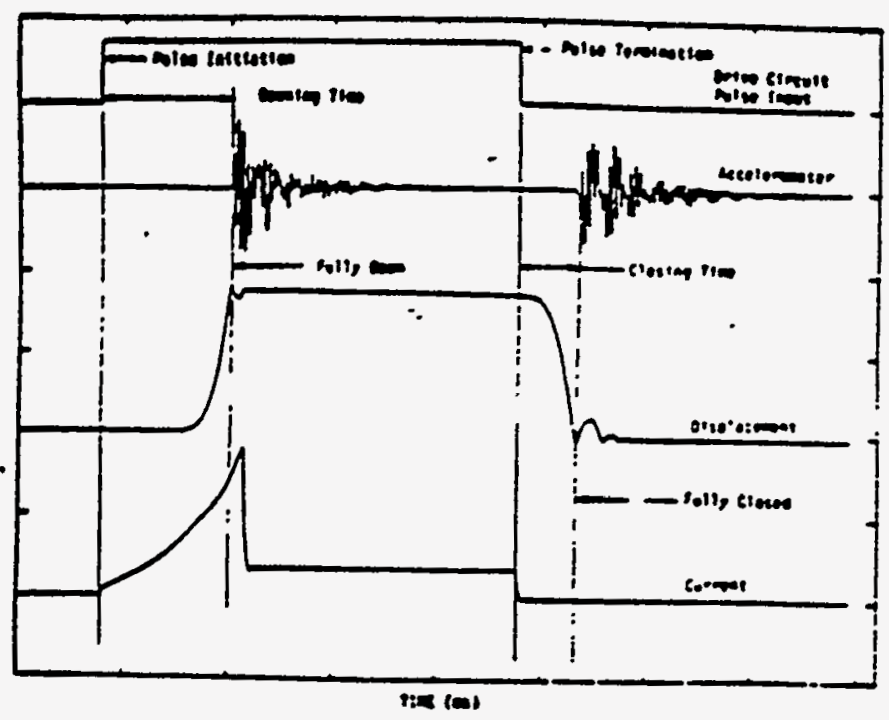

FIG. 72-TYPICAL OPENING AND CLOSING TME WITH PEAK AND HOLD DRIVER

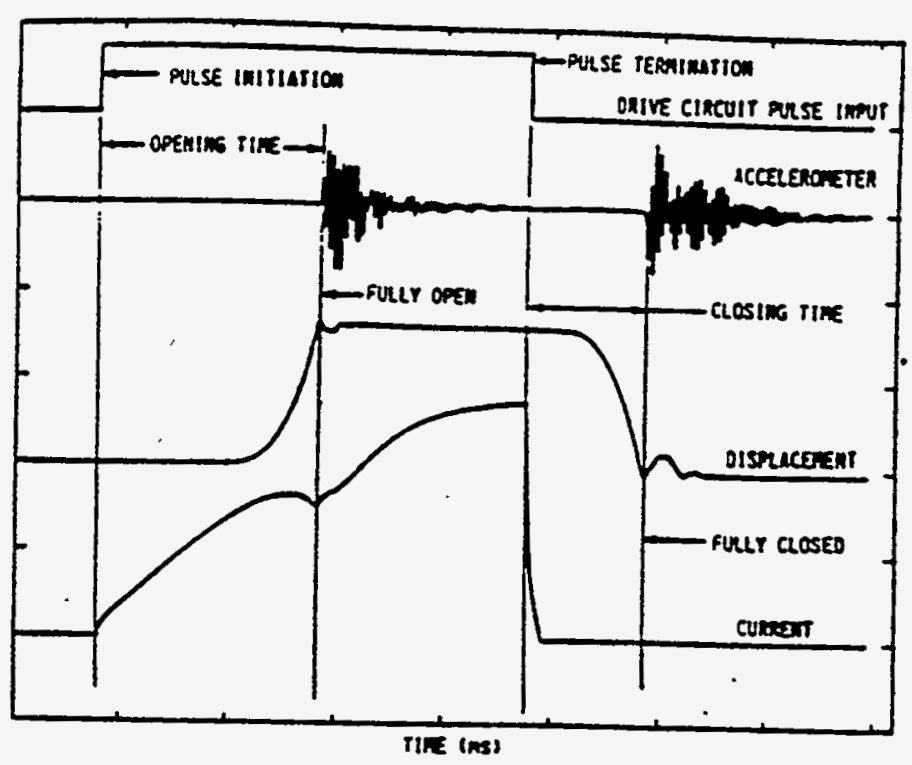

FIGURE 7b - Typical Opening and Closing Time Wth Saturated Driver

77G. 7-OPENING AND CLOSING TIME

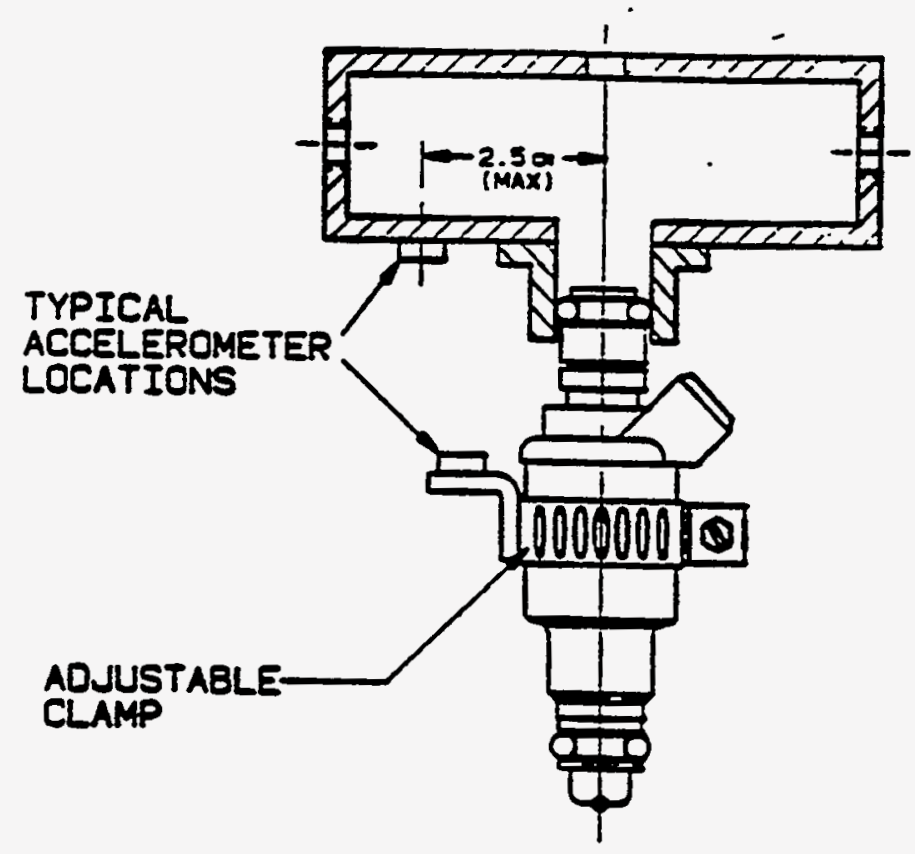

FIG. 8-ACCILROMETER MOUNTING LOCATIONS 
Radial spray characteristics are defined by the included angle and the distribution of fuel within that angle. The test fixtures shown in Figs. 9-14 illuserzte the recommeaded method of measuring the spray cone angle and distribution of fuel within the pareern as measured in still air. The spray cone angle for 2 hollow spray cone pattern is defined as the included angle where the maximum coscentration of fuel spraying from the injector is convained (Fig. 11). The spray cone angle for a solid sprizy cone pattern is defined as the included angle where $95 \%$ of the fuel spraying from the injector is convained (Fig. 12).

The collection vessel used to measure spray angle (Figs. 9 and 10) consists of eight concentric circular chambers. The walls separating the chambers are $15 \mathrm{~mm}$ high and have a upered leading edge so aninimize rebound of the spray.

A pencil stream injector does not distribute liquid into a cone of significant angle. This test fixture is, therefore, inappropriate for testing sprays of less than $8 \mathrm{deg}$ included angle and should be repizeed by a high-walled vessel to reduee spray rebound.

The collection vessel used to measure spray distribution (Fig. 13) consises of six equally spaced wedge shaped chambers separated by 15 $\mathrm{mm}$ high walls with apered leadiog edget. Fig. 14 shows a recommend. ed method for mounting the injector. spray collectors, and burettes.

Specifiations for testing spray cone angle and fuel distribution for other types of systerns are not divaused since these syztems are still under development.

4.1.20.1 Spros Measurement Proceduse:

2. Tests to be conducted with a-Hepare as the control fluid.

b. Test to be conducted at prescure specified by appliation.

c. Tests to be conducted both at the dramie ser point pulse width and $\mathbf{Q}$.

d. The collection vessel must be locared below the point of origin of the injector's spray cone angle 23 indicated in Table 3 and Fig. 10. This dirance is determined by the appliation. The point of origin of the spray cone angie must be specified from the injector's mounting surfice dawm.

c. The fuel injector must be centered over the collection vessel. The centerline of the injector mouncing diameter datum muse be held 20 within $0.023 \mathrm{~mm}$ of the orue pocition of the concentric ring collection vestel's centerline.

f. To provide repeatable readinge, the tex fixwure mux be thor. oughly wet down by pulsing the injector 2 minimum of 10000 pules. The fuel may be collected from the fixcure drain holes in burettes for volumetric comparison or weighed for mass comparison.

g. The distriburion of fluid for spray angle and radial divtribution shall be defined by the user.

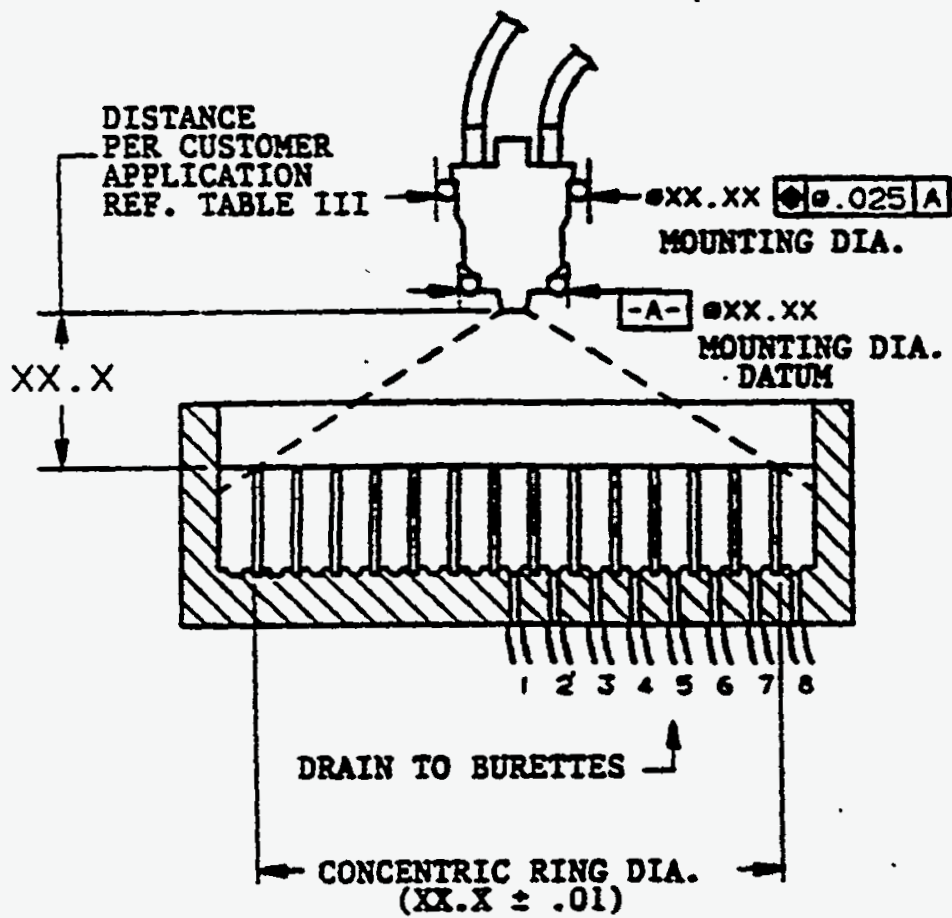

FIG. 9-RADIAL SPRAY COLIECTION VESSEL

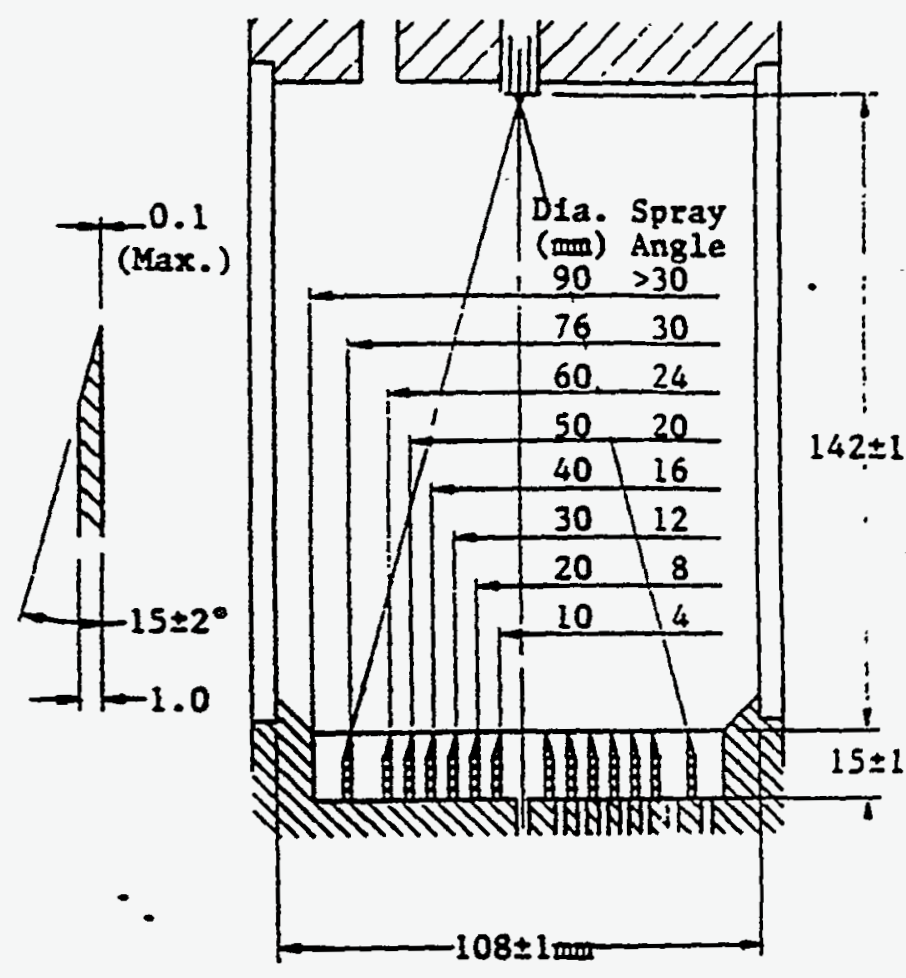

FIG. 10-TYPICAL SETUP FOR 30 DEG CONE'SPRAY

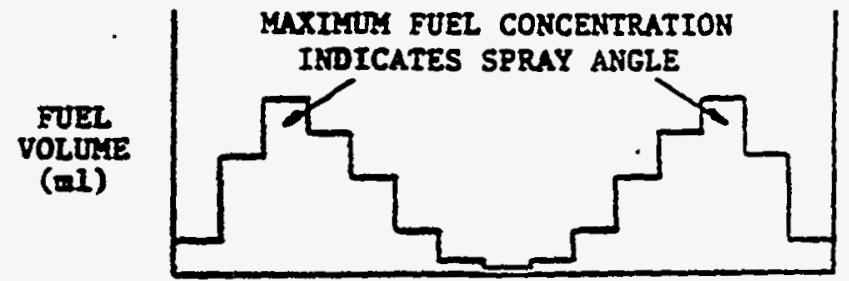

FTG. 11-TYPICAL FUEI DISTRIBUTION OF WIDE ANGLE HOLIOW CONE SPRAY

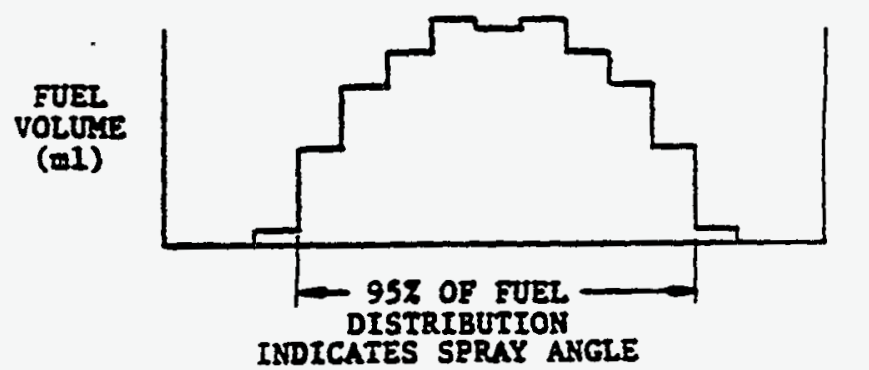

FIG. 12-TYPICAL FUEL DISTRIBUTION OF SOLID CONE SPRAY 


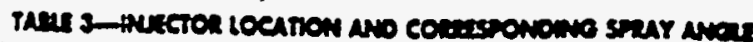

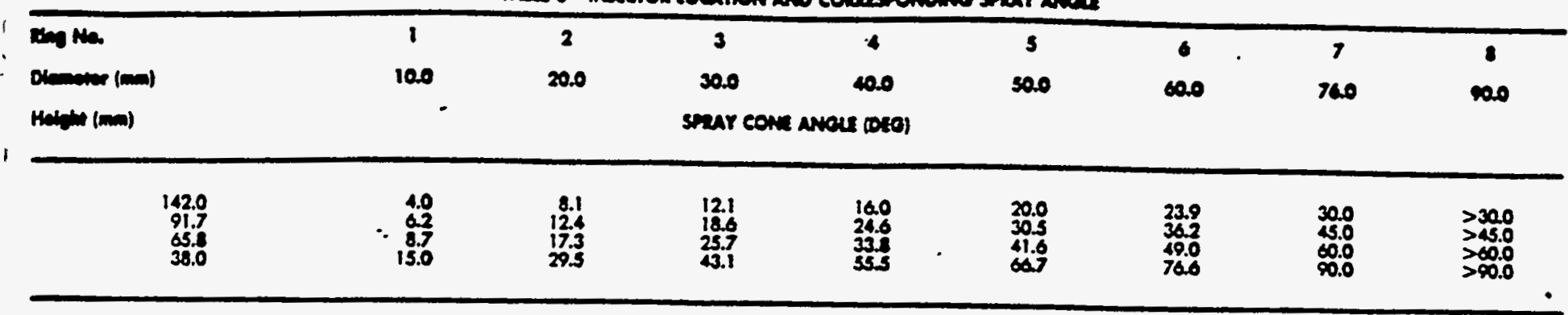
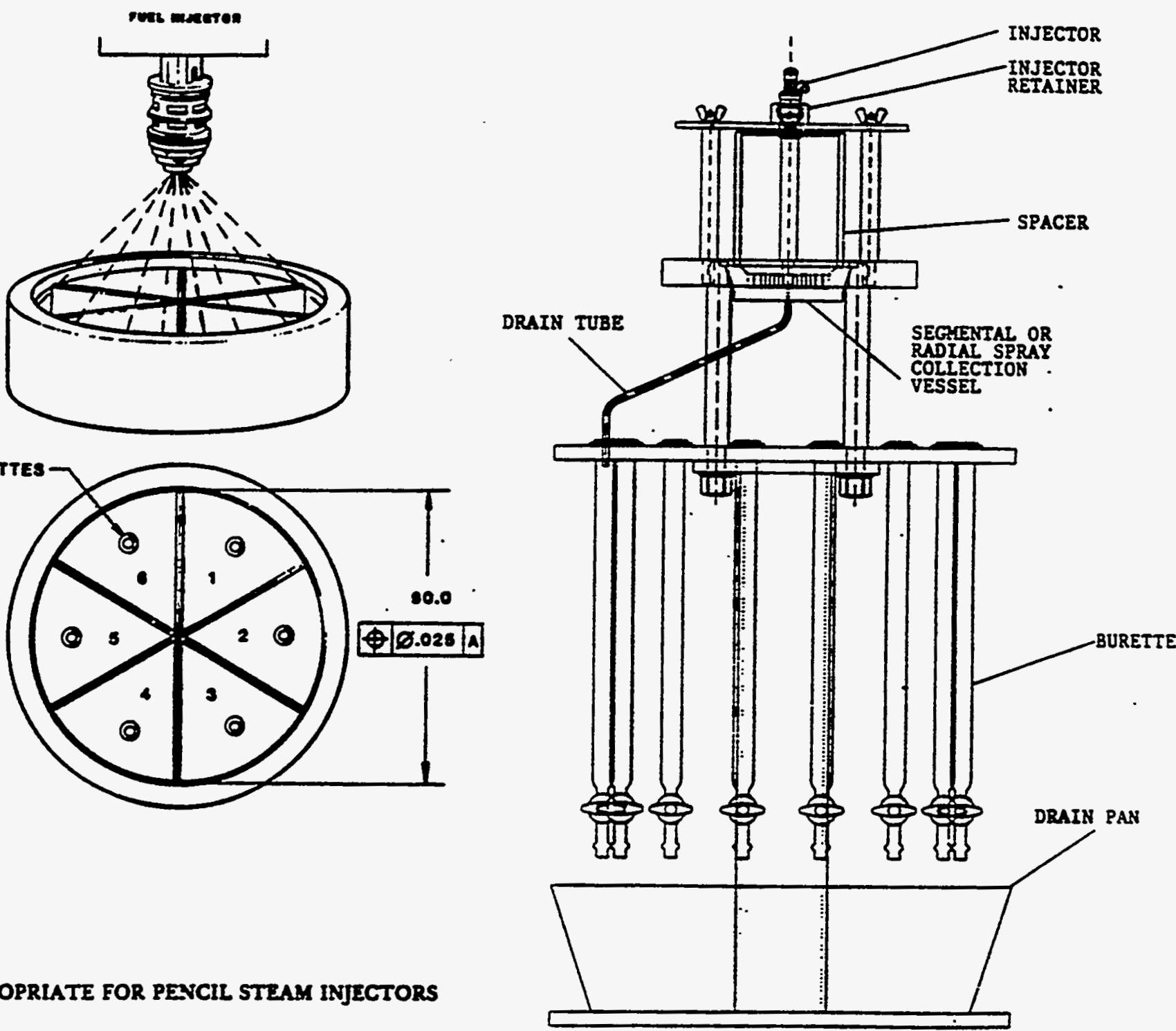

FIG. 13-SEGMENTED SPRAY COLLECTION VESSEI

FIG. 14-SPRAY DISTRIBUTION TEST FIXTURE 
4.1.21 Extranal. LEakace-No visible fluid leakage at working pres sure is permitced in any area other than the seat. This inctodes the body, its seals, and the extermal O-rings.

The injector sent generally has meat-to-metal sealing surfaces for durability reasons. A leak tight interface is required between the mating surfeces of the injector valve seats components to maintain fuet pres sure, prevent abnormal fuel accumulation in the invake manifold, and reduce deposit formation at the injector orifice. Seat leakage mar result in 2 leaner or richer A/E zatio depending on such variables as leakage rate, temperature, and soak period.

Las of pressure during extended periods of engine shutdown under hot ambient conditions may cause excessive fuel vaporization and incorrea fuel delivery during start-up. The increased time required to achieve desired rail pressure in combination with vapor enernined in the fuel delivered an result in incrensed cranking rime, rough idles, stalis and/or a nowstart condition.

Fuel leakage into the intake manifold may cause a richer than normal A/F ratio during startup. Engine emissions may be adversely affected under these conditions. Even slight seepage may increvse deposit formation at the metering orifice of the injector. Deposits so formed can partially plug the orifice and reduce the fuel delivered, which adversely affea both vehicle emiscions and driveability (see 3.4).

Seat leakage can be specified as either 2 test fuel leak rate or 2 gas leatage nie. The preferred method is the use of dry nitrogen as the cest medium.

4.1.21.1 Srat Leakere Test Procodure-The injector must be in a clean and dry condition in order so obrain an accurate repeatable leakage test. All liquid rest fluid contained in the injector must be removed, since 2 nonexisting tightness is simulated if the sent is moistened.

4.1.21.1.1 Drying Procedure-

2. Flush injector with n-Heprane per preconditioning procedure 3.9.3.

b. Apply dry nitrogen at $60 \mathrm{kP2}$ to the inlet of the injector with the tip pointing down.

c. Dry injector by accuating at a PW of $2.5 \mathrm{~ms}$ and $5.0 \mathrm{~ms} P$ for a minimum of 6000 pulise ( 30.0 s).

d. Orient injector with tip pointing up.

e. Dry injector agin for 90.0 s using dry nitrogen as $60 \mathrm{kPz}$ while the injector is actuneed at $2.5 \mathrm{~ms} P W$ and $5.0 \mathrm{~ms} P$.

4.1.21.1.2 Measurement Procedure-

2. Measure the leakage rate using any highh senvitive gas volo ume sensor. As aceepuble method is to immerse the injector with its tip pointing up into a coneainer filled with mineral spirizs or equivalent.

b. Surpend the mouth of a graduated cylinder previousty filled with rex fluid above the ip of the injector.

c. Apply dy nitrogen at $20^{\circ} \mathrm{C} \pm 1$ within $=2 \%$ of gyreen pres. sure to the injector inles for $5 \mathrm{~min}$ with the injector valve seat cloced.

d. The collected bubbles represent the injector air lest rate. The permissible leakage is dependent on the appliencion (normally less than $1.5 \mathrm{cc} / \mathrm{min}$ ).

4.1.22 Orantine Voltact RANer-Under cervin circumstances, such as cold engine cranking, normal operating voluge is noc available. The minimum opening volenge of the injector is especillly critical for high resirance injectors as che coil arrent is direchly proportional to the available voluge. Low reximnce injectors are not as semitive to lower battery voluge due to the current limiting driver circuit charae. terisios (Fis. 13).

4.1.22.1 Static Minimin Opreting Voltare (SMOV) -This is the voltage, measured at the injector electriel connector, at which the injector opens as determined by an sccelerometer or ocher sensing device apeble of detecting the commencemens of fluid flow.

4.1.22.1.1 Tex Procedure:

2. Mount the injector in the ten fixure under the sandard test conditions per Section 3.

b. While mensuring the volage at the electrial connector, raise the supply voluge in $0.10 \mathrm{~V}$ steps every $20.0 \mathrm{me}$

C. Reeord the voltine when the injector coens.

4.1.22.2 Dynewic Mininum Operating Vollere (DMON)-This parameter is 2 measure of the fuel injection strems response to low voleage conditions. The driver circuit has a significant effect on the injector response characteristics; therefore, the driver circuit as used in the vehicle muse be used.

4.1.22.2.1 Test Procedure:

a. Mount the injector in the test fixture under the seandard test conditions per Section 3. b. Using the driver circuit from the vehicie appliation. raise the supply volage to the driver in stept of $0.10 \mathrm{~V}$ starting at the SMOV. The logic pulse to the driver is to be a period of 20.6 ms and a PW of $10.0 \mathrm{~ms}$. A minimum of 1000 pulses are to be supplied at each step.

c. Measure the supply voltage and the injector flow rate at each step point.

d. The DMOV is that volage at which the flow rate exceeds $50 \%$ of the flow at $14.0 \mathrm{~V}$.

This test may also be modified to generate a volage compensation curve for the system by continuing readings beyond the minimum opening point and using other PWs to create the family of curves similar to those in Fig. 13.

4.1.22.3 Marimen Overload Voltage-The injector must mainain calibration after a maximum of $24.0 \mathrm{~V}$ is applied to the driver for a perod of $60 \mathrm{~s}$. This test is intended to simulate an incorrect jump start condicion.

The injector and driver are tested as an asembly with the injector operating at $\mathbf{Q}$ and system pressure. Test voleage must noe be applied directly to the injector terminals for damage may occur.

4.1.25 STAtic PuzLis Current (I/S-ON)-I/S-ON is the minimum current required to actuate the injector from the closed to the open po sition. It can be used to calculate the SMOV if multiplied by the R and can be useful information in dingnosing functional problems and de. signing of injector driver circuits.

The recommended method of mearurement is to increase current to the injector in a stairease waveform with 2 sep height of $1.0 \mathrm{~mA}$ and 2 width of 10.0 ms until the injector opens as indiated by an acceler. ometer sigmal or other sensing device capable of detecting commencement of fluid flow. The injector must be mounted with the nozzle pointing downward and with system presure applied to the inlet. Seart tert at $90 \%$ of anticipated I/S-ON current to avoid overheating the injecror.
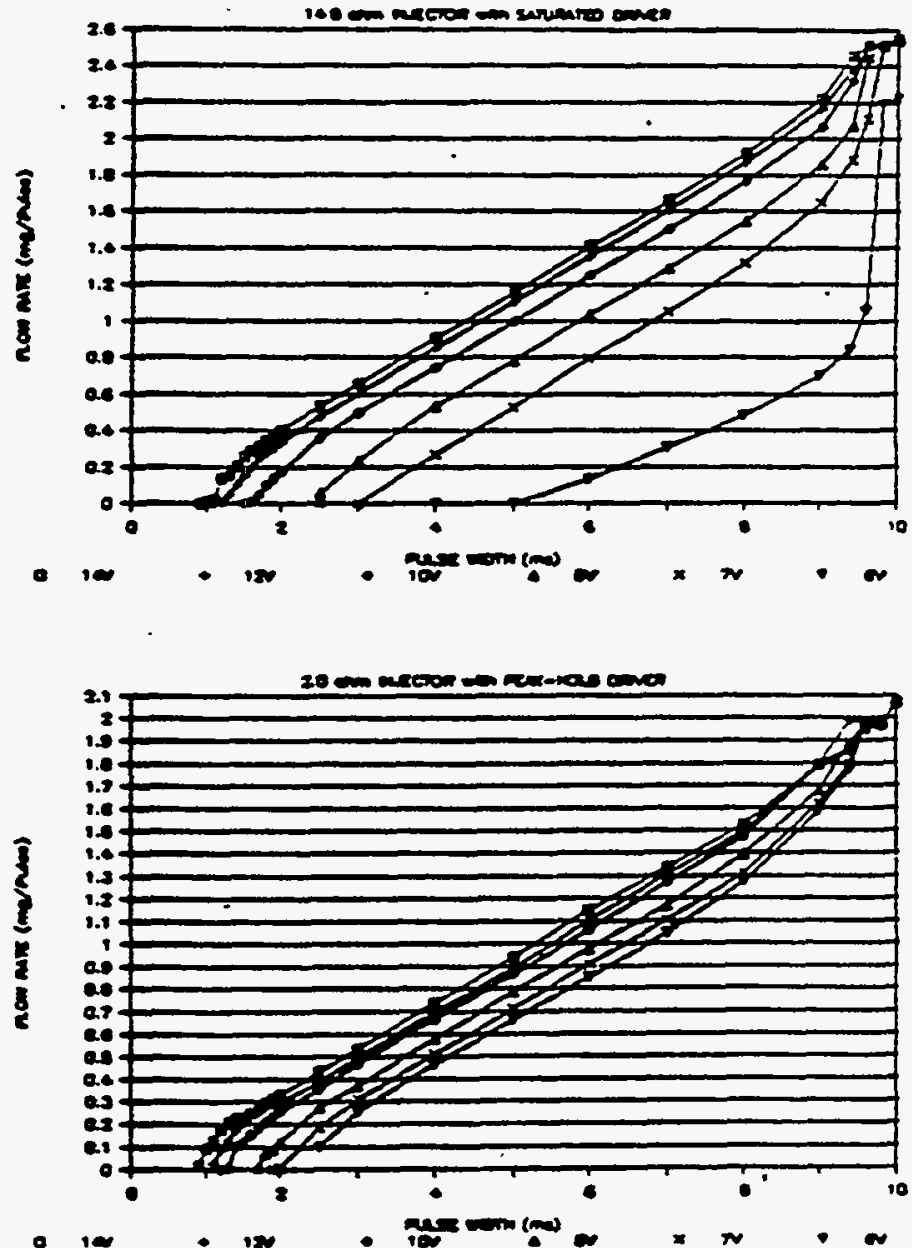

FIG. 15-EFFECT OF VOLIAGE ON PERFORMA.VCE 
4.1.24 Static Dror-OUt Clirrent (I/S-OFF)-I/S-OFF is the minimum current required to hold the injector open after it has beed energited It is used to determine the holding current alibrtion of the penthold driver.

The recommended method of measurement is to apply sufficient current 20 assure that the injector is in the open position and thea to decreve the current in 2 seairease waveform with 2 step height of $1.0 \mathrm{~mA}$ and a width of $10.0 \mathrm{~ms}$ until the -injector closes as indiated by an 2ccel. eromerer sigmal or other sensing device capable of desecting cessation of fluid flow. The injector mus be mounted with the nozrie pointing dowaward and with system pressure applied to the inlet.

The I/S-OFF is always lower than the I/S-ON because the solenoid air gap is smaller by the amount of the stroke, which will yield higher magmeric forees for any given current level. The drop-out current is generaily mezsured immediztely following the pull-in cursent messuremeet.

4.L.25 Pressuri Drop Ratio (PDR)-A ratio of the fuel pressure drop actoss the metering orifice of an injeztor compared to the fuel pre-ure drop across the valve seat.

The PDR is useful in evaluating the sensitivity of an injector design returive to the metering of hor fuel. Calculations an be made to deter. mine if fuel exiting the metering are of the injector will vaporize if the PDR, fuel iniet pressure, fuel volatility, and maximum application tem. perawure are known. This ascumes that the valve/seat and the metering orifice are the primary restrictions to how. If additional signifient premure drope occur within an injector design, they must be accounted for before any hos fuel handling predictions are made. Since an injector is designed to meter a liquid, fuel vapor annot be acrurateiy metered and steps to minimize this condition should be taken.

4.1.26 Insulation Riststance (IR)-This tex is derigned to check for 2 poteatial failure of the innihtion between the coil astembly and the ase of the injector. It is usually performed on completed injectors to ensure that the coil insulation has not been damaged during the as sembly proress and that the terminal to case clearnoce has been adequacely maintained. IR is also measured after any mechanical integrity teing to ensure that the insulating abilities of the injector coil assem. b) bave noc been degraded.

In mout existing applications, a poxitive batuen volage is continuousI) applied to one of the injector terminals and the unit is energized by completing the ground cireuil In a simation where the IR breats down. the injector could become continuously energized and flood the engine. On syrtems thas energize the unit by providing the positive votage through the driver, breakdown can ause the injector to misfire of not fire at all depending on where the coil aswembly is shored.

4.1.26.1 Tast Procedure-Consect a standard megaohmineter tes. ter. set io $730 \mathrm{~V}$ DC, between the injector ase and 2 coil terminal post. The minimum allowable resirnace reading thall be $340 \mathrm{k} 0$ afrer $2 \mathrm{~g}$.

\section{Aptlication Reloted Paranoter and Tate}

5.1 Injector Ditres-An electronic circuit thas supplies voluge pules to an electromagnetic fuel injector for a precive increment of time and at a given repetition rate. The sceurecy of these pulses and their reperition is normally $\pm 0.001 \mathrm{~ms}$. The pent-hold driver and the smarted driver are mox commonty used by the industry for vehiele applications.

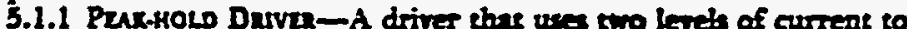
operate the injector (Fig. 16). The driver circuix applies buttery voluge to the injector until a predetermised current level is resebed. The cur. reas is then seduced and held at 2 lower level for the durution of the PW. This type of driver is normally used with injectors having low re sirance coils (typically around $2 \mathrm{ch}$. The secursey of the driver peak currene level $\left(I_{p}\right)$ and the bold current level $\left(I_{Q}\right)$ is held $20 \pm 0.50 \%$. Noce-In onder to minimise OT insenbility, is is advituble to match the injector and driver characterivolos such that the switch from peat-tohold does not occur unil after the injector is fully open.

ADVANTAGES: The high peak current minimizes OT response and the low hold eurreat minimizes CT re sponse. This method of control resules in $2 n$ increased linear range of injecror operncion.

DISADVANTAGES: Heat is primarily disupued at the driver. Cis. cuits is more complex than that of the sarursted driver.

5.1.2 SATURATw Darva-A power trandiator driver that curns fully on for the entire duration of the injeceor PW (Fig. 17). This type of driver is used with injectors having high resirance coils (typially 12 to $16 \mathrm{D}$ ) or with injectors having low resiscance coils in combination with 2 ballase resiruor.

ADVANTACES: Heat is primarily distipated through the injector or ballan resinor and nok at the driver circus.

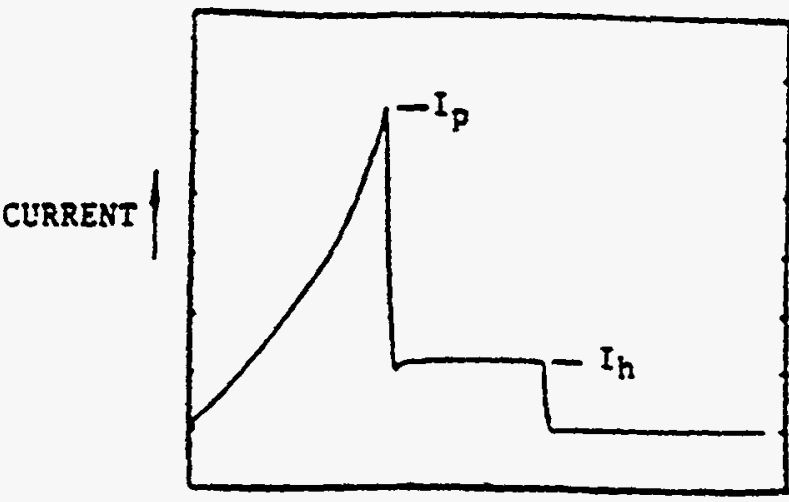

TIME -

FIG. 16-TYPICAL INJECTOR CURRENT WITH PEAK-HOLD DRIVER

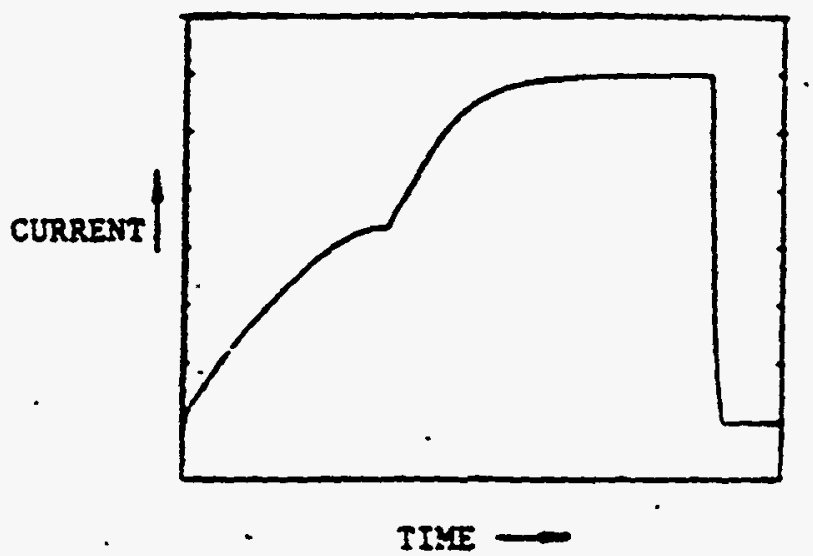

FIG. 17-TYPICAL INJECTOR CURREVT WITH SATURATED DRTVER

Circuitry is simplified compared to the peakhold drives.

DISADVANTAGES: The inberently slower dynamic response of this syued decreves the injector's usable fow range. The $Q$ of an injector used with this type of circoit is more dury crcie sensivive due to hent divipution cossiderations. This driver's indocine supresion, which miy be texiseancecapeciunce of zeot, signifientily affects the injecos's Q4 rates due to variations in the circuit's enrent dees rate. This deay results in 2 change of the injector's clocing time.

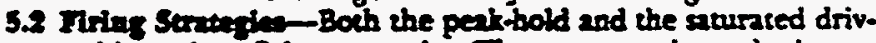
ers are used in various firing sarategies. Three commonly used schemes are simulaneous double fire, sequeatial singie fire, and alternating double fire (see Fig. 18).

5.2.1 SivULTANious Doutur Fns (SDF)-A moluipoint fuel delivery iechnque in which all injectors in a 4-creie engine are energized simul. ancously once per crantechafe revolution. 
5.2.2 SEquentral Fuel INJection (SFI) - A multipoint fuel deliverfi technique in which each injecror is individually energized and timed relative to its cylinder event. Fuet is delivered to each cylinder once per two crankshafe revolutions in t-gyele engines and once per crankshaft revolution in 2-cycle engines.

5.2.3 Altzanatting Dounte Fine (ADF)-A multipoint fuel delivery technique in which the injectors are energized in groups once per crankshaft revolution.

3.3 Operating Temperature Rang-This procedure is designed to evaluate injector performance when exposed to thermal conditions. Injector performance diva is taken both before and after the prescribed thermal cycle to determine if any degradation has occurred as a result of the experienced temperature extremes and/or temperature cycles. Performance data for this test shall include, but not be limited to, Q, Q IR and fluid leakage. The accepeable performance limies and the temperature levels used during testing are determined by the vehicle application.

5.3.1 Hot Static Sonx-Purge all fluids from the injector and expose it 20 a stabilized ambient temperature of $150^{\circ} \mathrm{C} \pm 2$ for $16 \mathrm{~h}$. The injector is not operated during this tere

5.3.2 Cold Static SOax-Punge all fluids from the injector and $e x$ pose it to a stabilized ambient of $-40^{\circ} \mathrm{C} \pm 2$ for $16 \mathrm{~h}$. The injecror is usually not operated during this test.

5.3.3 Crctic SOAx-Expoce the injector to the het thermocycle shown in Fig. 19 for a total of 140 cyeles. The unjector is to be operztional onty during segment D-E of the cycle, using a PW of 2 ans and 2 period of $7 \mathrm{~ms}$. The test shall be run with indolene.

5.4 Injector Fouling in Servica-Fuel injectors muse retain their alibration while in use in order to renis satisfactory engine performance, driveability and emission control levels. Cleanliness of the injector merering orifices and spray-forming nozales must be maintained in order for initial calibration to be dependable after extended use. Because this elementary requiremeat has noc been universally achieved, fuel injected engines of today require areful choice of fuel supply, additive treatment, or periodic injector cleaning to achieve permanent flow seability.

A variety of injector design approaches to mainvain calibration on "problem" fuels are being investigated as this document goes to press. Opertorifice injectors may maintain clibration better than annularorifice types. All designers of injection systems today must ensure that their products are supported by a plan that will secure depeadable op eration by the users.

The major location of injector flow restriction due to dirt or deposit accumulation is in the tip aree of high preasure multipoint electronic injectors. Unserble grsolines $\mathrm{cm}$, in mulistop city driving, build up a varnish-ilke deposit on the injector tip. These deposits reduce fuel flow through the annular orifice and cause lean engine operation and all the attendant driveability faules. The fulty operation pervirts until the injecrors are cleaned or replaced.

Clenning of injectors in service can be secomplished with in-tank additives to fuel, by solvent-elenning of insenlled injectors, or by ulursonic cleaning of removed injectors.

Fuel chemingry an stop or reverse depotit accumulation in the injector tip area. Gasolines with low olefin conteert (as produced from refineries with no cracking unitu) seem immune to the problem. Gasoline with subsenninl levels of creited or pohmer componens require areful additive treateneat with decengent-dipperwant chemicals to maineain injector cleanlines. Higher levets of these derergent-dipperant additres an reverse depocit buithp in service and clean injectors, which were deposit-restricted an obber fuets Some gasoline marteters in the Unived States identify weh injector-clening grsoline formularions at the point of purchase.

Fuets with high levets of boeh lead allyi antiknock and sulfur $(>2.0$ 8PO/usg and $>0.15 \%$ S) may phug injecrors regardless of base fuet formation. High additive leveis may alwas be required in such fuels and an injector of fouling-resistant design may be required.

5.5 Snlt Corrotion- This cert is to be applied 20 gnsoline injectors to ensure that they an withwand the effects of external salt corrowon. which is likety 20 be encountered on seaside marine applications and salty roed conditions (Reference ASTM B 117.85).

\subsubsection{Test Procioune}

2. The injector shall have its inlex and outlet suitably sealed. The injector is to have its electrical connector fittedi however. It is not to be energized.

b. Samples shall be supported or surpended between 15 and 30 def from the vertical, with any significant surface parallel to the principel direction of fog how.
CYL

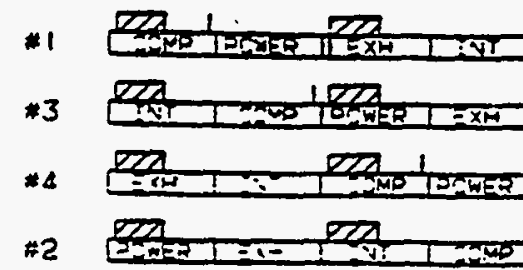

SIMULTANEOUS

DOUBLE

FIRE

CYL

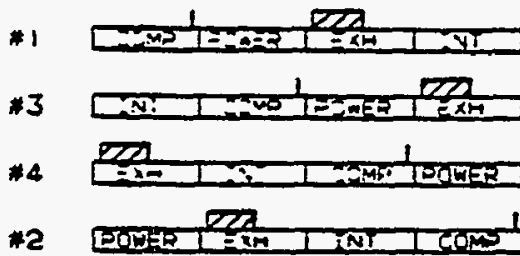

SEOUENTIAL

SINGLE

FIRE

CYL

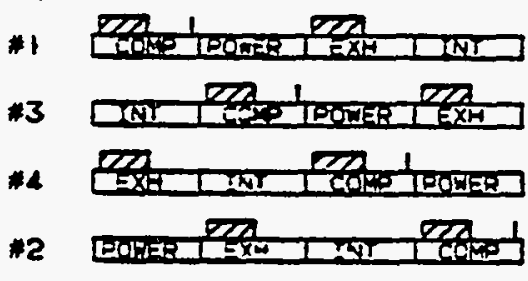

ALTERNATING

DOUBLE

FIRE

1 -IGNITION

QZA -FUEL INJECTIS

FG. 18-PORT FUEI INJECTION FIRING STRATEGIES

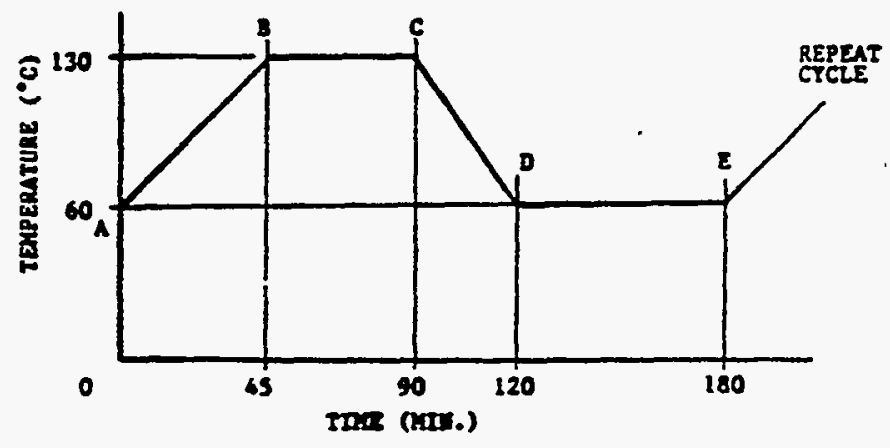

F1G. 19-THEXMOCYCLE TIME SCHEDULE

C. Sumpies shail be at leas $30 \mathrm{~mm}$ from each other and $33 \mathrm{~mm}$ frow a chamber will.

d. Sample shall be so pleced 25 wo permit free seteling of fog of all somples but anoid salk sohution from ose sample dripping cons ancecher.

e. Erpoce the anples in the for chamber for a period of $96 \mathrm{~h}$. Inpeet the sampies and operition of the chamber as required Opering of the chnmber anall be limited to the frequency nee. exary to arry cut the cperscions. Inspections should not bx made more than twice a day for a rocal of 15 min. Position of the enoples may be varied during the inspection penod.

f. Rewove the moples, wash gently in water not warmer than $38^{\circ} \mathrm{C}$, and ing by blocting with aboctbent paper. 
3.3.2 Consosion Assessment-Each injector tested shall be examined immediately after texting. The degree of corrosion shall be visually ar essed in accordance with 3.5.3.

Each injecsor tested shall mees the performance requiremens deteiled in 5.5.4 prior to and after the completion of testing.

5.5.3 Surracz Corrosion And Bustzanc-For the purpose of this documene, a "signifieant surface" is tefined $2 s$ an aren desigmed to be coated that can be touched by $26.35 \mathrm{~mm}$ diameter ball.

Any spots of red rust on a significane surface shall be cave for rejescion. Rust spots on surfaces, which annot be touched by $26.35 \mathrm{~mm}$ ball, shall be noted but will not be cause for rejection.

Any blistering of the coating shall be noted as to location on the sam. ple piece, blistering size, and number of blisters. Blistering on signifiane surfaces shall be cause for rejection. An excess of three blisters of $1.0 \mathrm{~mm}$ diameter on surfaces, which cannot be rouched by a $6.35 \mathrm{~mm}$ ball, shall be cause for rejection.

5.5.4 Perrormance Assessment-Each injector shall be zerted for $Q$ (4.1.3), $Q(4.1 .4), I R(4.1 .26), R(4.1 .18)$, and leakage (4.1.21) prior to and after completion of corrotion teses. $Q$ and $Q$ deviation shall be reporred as a percentage (Reference 5.9.3).

5.6 Fuid Compatibillty (Externs)-This text is to be applied to the external surface of a gasoline injector, excluding extermal Q-rings. to ensure the external surfaces can withweand contace with common aucomotive fluids.

5.6.1 TES Flutos-it is not prectical to evaluate all variations of test fluids, therefore, agreed reference fluids are employed in tesing. The mout commoniy used fluids are listed as follows:

A reference fluid is defined $2 s$ material representative of is paricu. has group, which is sufficiently well defined in all respeces so that supplies from different sources are escentinlly identiol in action for which the test is intended (Reference ASTM D 471-79).

ANTIFrREzE $30 \%$-Shall be an echylene giycol based material as described in SAE 1814 mixed with an equal volume of water.

AUTOMATIC TRANSMISsION FUTD-Shall be Dexrop II (General Motors Regivered Trademark) or equivalent.

AXIE AND MANUAL TLANSYTSSION IUDRTCANTS-Gear Oil API-GL-5 as described in SAE J308. (Vicconicy as defined in SAE J306 may be specified at the option of the test engineer.)

BATTERY ELECTROLYT2-Shall be reagent-grade sulfuric acid diluted with water to a specific gravity of 1.25 to 1.28 .

DRATE FLUID-Is a mixture of polygitycols and cellosolves conforming 20 DOT-3 of 49 CFR 571.116 .

BUTYLCELLOSOLVT-Technical grade.

DIESEL FUER (NO. 2)-As described by SAE J313. The fluid shall have an Aniline point of 60 to $70^{\circ} \mathrm{C}$. It is preferred thas emissions grade diesel fuel conforming to 40 CFR $86.113-82$ be used.

ENGINE OIL-Shall be ASTM Reference Oil No. 3.

INDOLENE-Shall be US EPA emimion dan fuel.

GASOLINE AND 20\% MITHANOL-Shall be $20 \% \mathrm{v} / \mathrm{v}$ reagent. grade methanol added to gawoline.

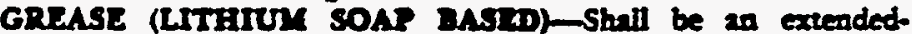
lubrication-interval grease as described in SAI 1310. Whep tented to ASTM D 128, it shall convain not lese than $4 \%$ by weighe Liehiven (12Hydroxystearate type).

MINERAR SPIRTIS-See Table 2.

1,1,1-TRICALOROETKANL-Shall meer the requirements of Military Standard MIL-C-81533.

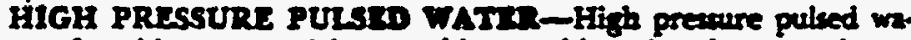
ter, as found in commercial ar wahing mechines, is to be yprayed over the exterior surfaces of the injexter for 15 \& Notr: Lax step of 3.6 .2 does noe apply.

STLAM CLEANING_Stens clenoin, as found in commencial equipment, is to be sprayed over the exterior surface of the injector for 15 s. Notz: Last step of 5.6.2 does not apply.

5.6.2 Test Phocmurt-Texting an injector with oos fluid followed by another fluid is to be avoided.

2. Each injector shall have is inles and outle surably sealed. The injector is to bave its electrienl connector fitted; however, it is not 20 be energized.

b. The injector shall have its expowed arfaces dampened either by epraying or bruh application and allowed to stand for 24 h.

c. On completion of the $24 \mathrm{~h}$ period, the injector shall be degreased using 1,1.1-Trichloroethane or equivalent.

5.6.3 Asurssurnt Or Rusurts-Each injector tesued shall be examined immediacely after resuing. The external surface condivion shall be visually arsesued in accordunce with 3.5.3.
Each injector tested shall meer the performance requirements deailed in 5.5.4 prior to and after the completion of testing.

5.7 Fitdd Compatibility (Inturail)-This test is used to determine the compatibility of internal fuel injector components with fluids similar to those that may be found in the vehicie's fuel system.

5.7.1 Test Fluids-It is not practial to evaluate all test fluids. therefore, agreed reference fluids are employed in this test. The most commonly used fluids are listed.

A reference fluid is defined as 2 material representative of its particu. lar group, which is sufficiently well defined in all respects so that sup plies from different sources are escentially ideatical in action for which the test is intended (Reference ASTM D 471 79).

WATER/GASOLINE SOLUTTON-Mix by volume, $98 \%$ uniezided gesoline and $2 \%$ corrosive water. Corrosive water is a solution formed by diswolving the following amounts of anhydrous sodium salts in one liter of distilled water at $40^{\circ} \mathrm{C}$ to aid the mixing:

$\begin{array}{ll}\text { Sodium Sulfate } & 14.8 \mathrm{mg} \\ \text { Sodium Chloride } & 16.5 \mathrm{mg} \\ \text { Sodium Bicarbonate } & 13.5 \mathrm{mg}\end{array}$

GASOLINE AND 20\% MTTHANOL-Shall be $20 \%$ by volume re agene-grade methanol added to unleaded gesoline.

GASOKOL-Shall be $10 \%$ by volume reagent-grade ethasol added to unieaded gasoline.

BUTXLCEIIOSOLVR-Shall be 59 by volume technial-grade Butyicellosolve added to unieaded gesoline.

OXIDIzED GASOLINT (Sour Ga)-Shall be mixed by the following procedure to achieve a peroxide number of 180 millimole/liter

a. Stock Fuel-Mix 70/30\% by volume a-Heptane/Toluene

b. Copper Ion Stock Solution-Due to the hazardous nature of these chemials, the solution must be prepared sequentially in the following three steps:

NOT: FAILLRE TO FOLLOW PROPER PROCEDURES CAN RE. SULT IN FIRE REFER TO OSHA MATERIAL SAFETY DATA SHEETS FOR ADDITIONAL INFORMATION:

(1) Add $10 \mathrm{~mL}$ of $12 \%$ copper ion concentrate solution to 990 ml of Stock Fuel.

(2) Add $100 \mathrm{~mL}$ of the solution from Step 1 to $1040 \mathrm{~mL}$ of Stock Fuel.

(3) Dilute $10 \mathrm{ml}$ of the solution from Step 2 with $990 \mathrm{~mL}$ of Stock Fuel.

c. Peroxide Stock Solution-Dilute $333 \mathrm{~mL}$ of $90 \%$ by weight tbutyl hydroperoxide with $663 \mathrm{~mL}$ of n-Heptane.

d. Test Solution-Dihute $60 \mathrm{~mL}$ of Peroxide Stock Solution with $10 \mathrm{mi}$ of Copper lon Stock Solution and $930 \mathrm{~mL}$ of Stock Fuel.

5.7.2 Trst Proceroure:

2. A new injector must be used for ench test fluid.

b. Precondicion per $\mathbf{3 . 9 . 3}$.

c. Submerge the injector in the solution for 30 days at room temperanse with the inlet port orientuted in a mander 10 keep the injector full.

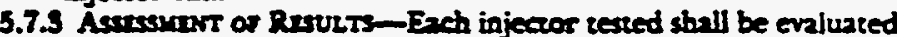
under standard text conditions (per Section 3) and performance mea. sured per 5.5.4 prior 10 and after completion of the teses.

5. Itsical Truta-Fuel injectors are subjected to various me chanial loads. These loads occur during manufecuring, testing, handing, and insallation in the vehicle fued syrem. During actual vehicle service, the injector is alvo subjected to various shocit and vibrational losdi. The purpore of phycical esting is to ensure that the injector's flow performance, electrial characersivion, and abence of leakage will remin within specification after being subjected to these types of forees.

5.8.1 TuT Fxxture Mountrave-Axial load, beoding moment. and torrioanl londs are apolied to the injector duriag insollhtion and re-

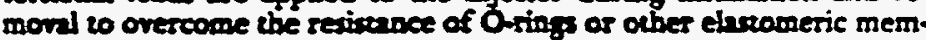
bers used for the purpore of sealing thermal and mechunical isolation. and compensation for part variations The are also subjected to loads resulting from mounting the fued rail $20 d /$ or retaining the injector.

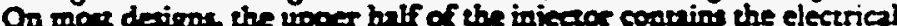
conpector and the lowes half the fud metering section. The loads are uavilly apolied to the injector by purhing aod swiscing the upper half relacive to the lower balf. One firture deaige will not accomonodate all injectors because of the variety of injector derigns and mounting meth. ods in use. The fixaure mum take into zecouns the specific injector de sign and application. The loads and fixnures used may, therefore, neces saniv deviate from that recommeoded in the following sections.

5.8.2 Assissment of Paronmake - Reference 3.3.4.

5.8.3 AxIAL Test Prociounz-The injector shall be mounted to a suicable fixture per the applicaion sequirement (Fig. 20) and subjected 

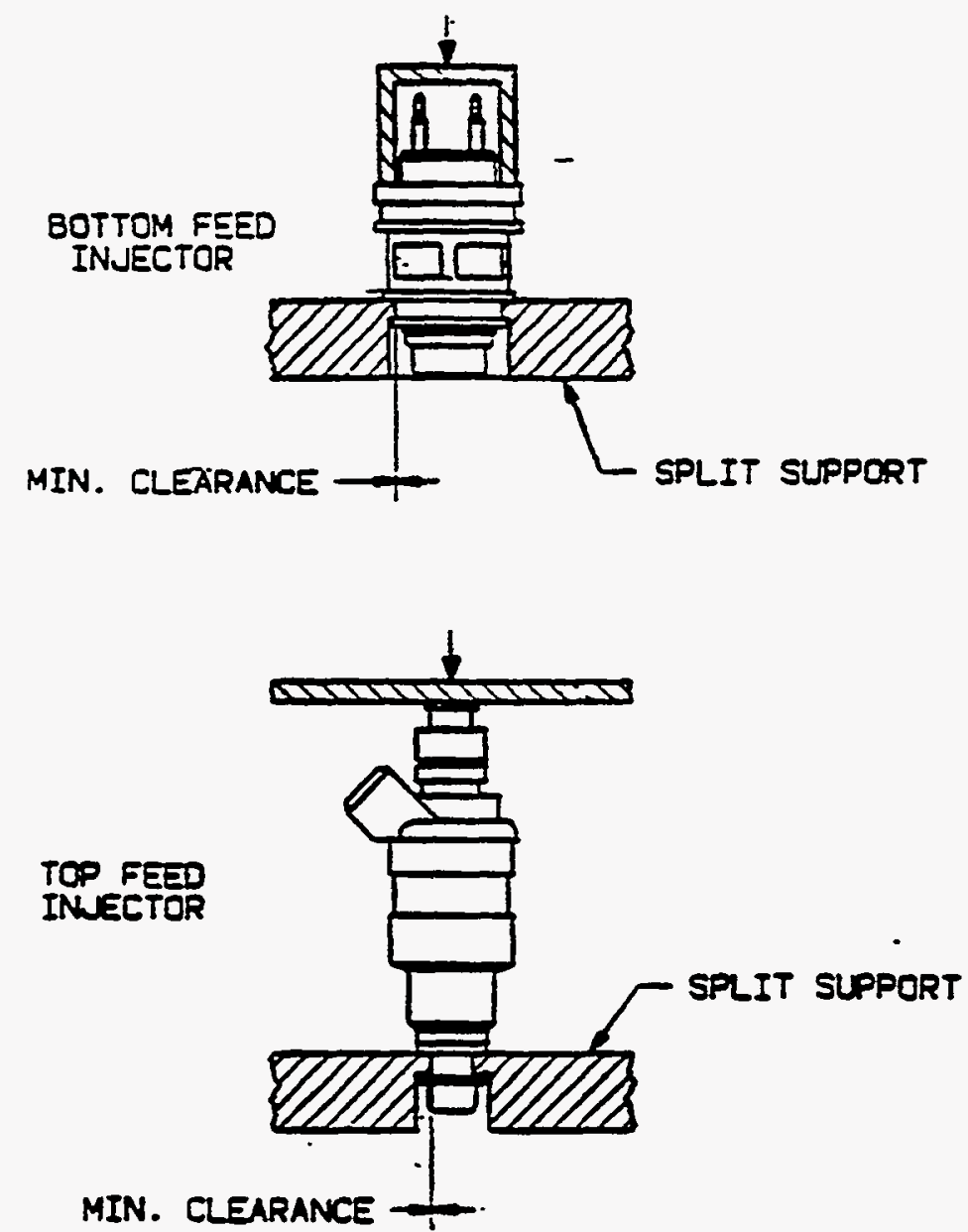

FG. 20-AXIAL LOAD FIXTURE

to 2 foree (typially $600 \mathrm{~N}$ ) applied along the longitudinal axis of the injector.

5.8.4 Torstonal Monent Test Procroure - The injector shall be mounted in 2 suitable fixture with the body fixed (Fir. 21) and a torsioml moment (typically $0.6 \mathrm{Nm}$ ) applied wo boch ends for $5 \mathrm{~s}$ about the longitudinal 2xis of the injector.

5.8.5 Berdinc Momert- The injector shall be mounted in a suitable fixure (Fig. 22) and subjected to a beading momeat (typically $6.0 \mathrm{Nm}$ ) for 30 s.

5.8.6 Vination Tert Procioune-Cap the injector inlet and ourlet with the injector full of rex fluid Mount the injector in a vibration tex fixture (Fig. 23) thas duplicates the appliestion mounting. Vibrate the injector in each of the three ares (bonpindinal, buerul, and vertiall). The vibration schedule is to be random with the frequency controlled over the range of 5 to $2000 \mathrm{~Hz}$, based on the actual rehicle apolication. Tex durzion is to be per the curtomer requirements and may be accel erated per random vibration practices (Reference Milinat Sundard 810-D). Accelerometers should be placed at ahe ame location as per ve hicle date acquivition. Vehicle dae collection should encompass any conditions that may represent worst curtomer unate.

5.8.7 SHock Tur Procrours-Cap the injecaor inlet and outler with the injector full of tex fluid. Moune the fuel injector onso a shoct text fixure that duplicates the application mounting (Fis. 23). Perform impaces at $30 \mathrm{C's}$ inpert load for a durztion of 11 to $14 \mathrm{mis}$ sin sines with the injector in the vertial poxition (vatve tip pointing dowmward) and six times with the injector in the horizontal position.

5.5 Besch Deribillty - This procedure defines a uniform test for evalwaing the minimum aecepable durability level of a given grooline fuel injector dexign.

5.9.1 Flushnnc Prociount-All tear samples are so be creled with test fluid for 1 min at a PW of 2.5 ms and a period of $5.0 \mathrm{~ms}$.
5.9.2 Injector Test Condritons:

a. Fuel Temperature Tes Range-17 to $30^{\circ} \mathrm{C}$

b. Fluid-Indolene

c. Fluid Condition-A fresh supply of fluid is 6 be used $a t$ the start of every tere, and changed at every $100 \times 10^{8}$ cycles of test (approximately $139 \mathrm{~h}$ )

d. Prescure-Determined by application

e. $P W-2.5 \mathrm{~ms}$

f. Period-(repecition race) $-5.0 \mathrm{~ms}$

g. Duration: Subjea to application

Typial PFI $600 \times 10^{6}$ pulses

Typicil CFI $900 \times 10^{6}$ pulses

5.9.3 Purorkance Curruia-The resi samples shall be evaluazed for the following flow crieriz:

2. Percent Static Flow Shif

End of Test Flow - Surt of Test Flow Star of Tex Flow $\times 100-\%$ Static Flow Shift

b. Percent Q, Shift at $2.5 \mathrm{~ms} \mathrm{PW}$ and $10 \mathrm{~ms}$ Period (calculated same as above)

c. Leakage Specifiexion-All test samples muse be evaluated for leakage as specified in 4.1.21.1.

3.9.4 Furouncy of Puronmance Criecrs - The tex samples shall be evaluated for the above criteria at least prior to the start and on com. pletion of the test schechle.

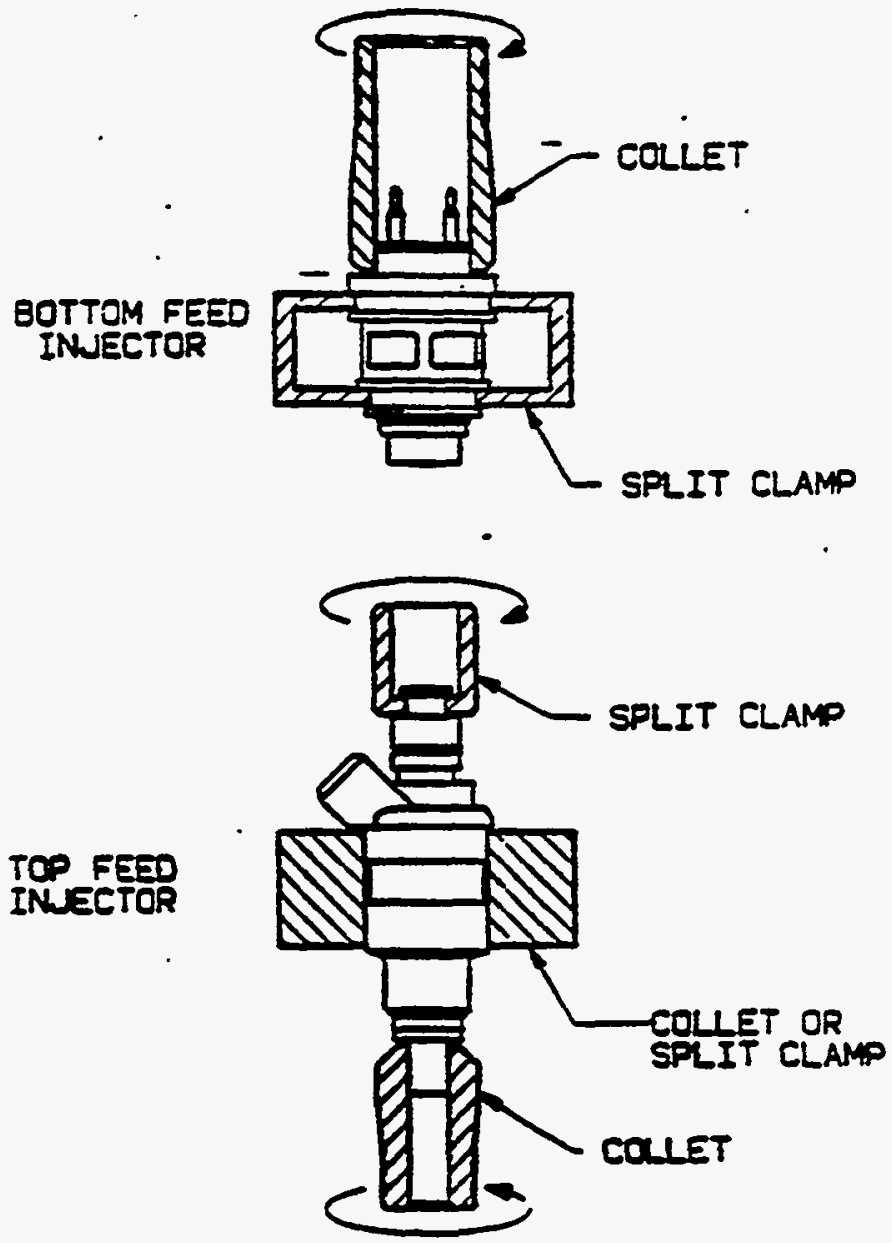



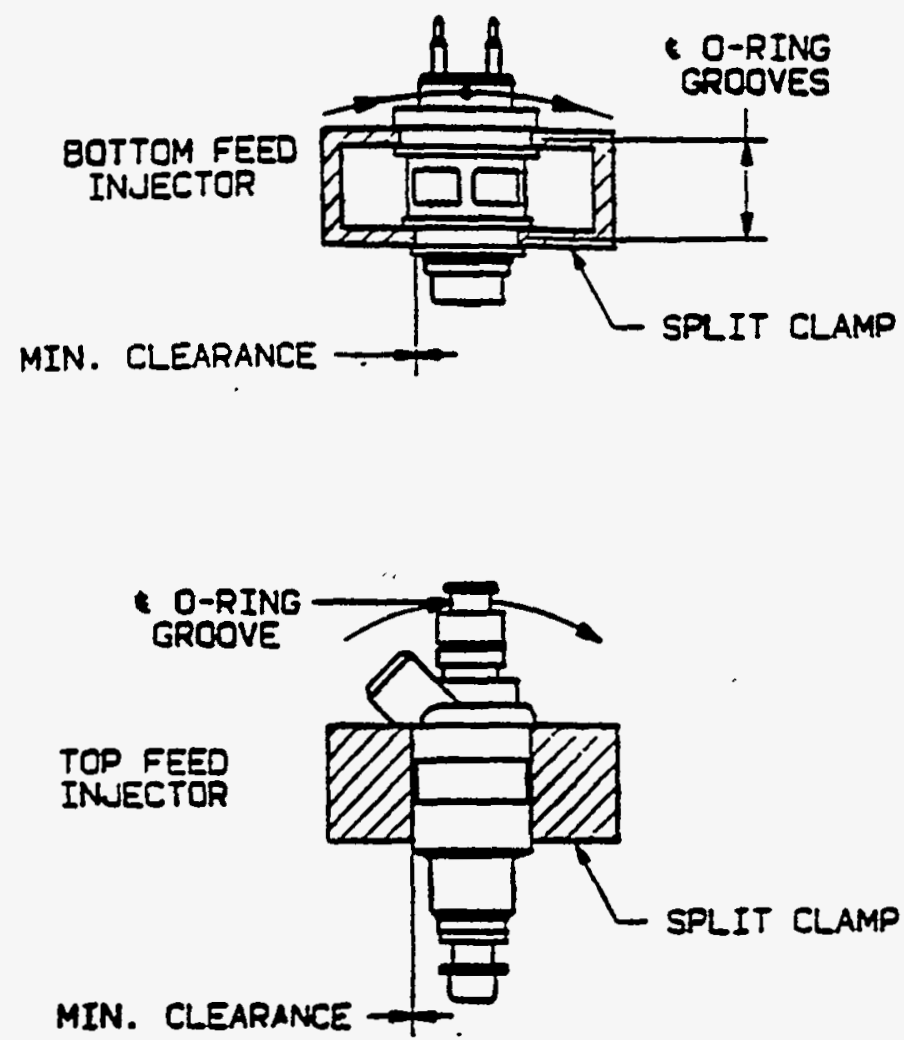

FIG. 22-BENDING MOMEVT FIXTLRE

USE SAME MOUNTING HARDWARE \& CAVITY DIMENSIONS AS USED IN VEHICLE APPLICATION.
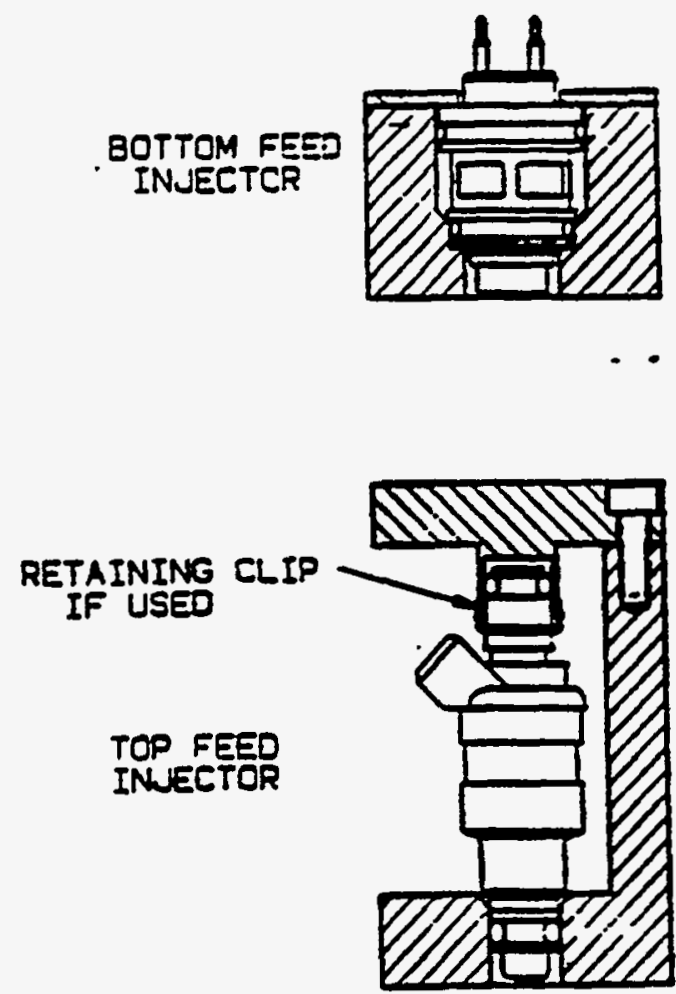

FIG. 23-SHOCK AND VIBRATION FIXTURE
New Designs/First Piece Samples will require additional flow test points during the accumulation of tex cycies. See the recommended flow schedule for such cases as follows:

$$
\begin{aligned}
& \stackrel{0}{25} \times 10^{\circ} \text { Erdate } \\
& 25 \times 105 \\
& 50 \times 100 \text { Cydien } \\
& 100 \times 10^{\circ} \text { Cydos } \\
& \text { Cormane of } 100 \times 10^{\circ} \mathrm{Cyd}
\end{aligned}
$$

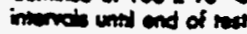

5.10 Hot Lean Shifl-Fuel injectors exhibit varying degrees of "hot lean shift" when operzed at high temperatures. An extreme condition will usually occur in hor weacher after 2 running engine has been shut down for about $30 \mathrm{~min}$ and thea restared. Both the injector and fuel temperature will rise during the "saak" period, causing reduced flow rates after the restart. The injector flow rates will gradually recover to normal levels as temperatures drop to a stable operating range. The magnirude of the lean shift is rebued to the injector design, fuel system components, injector's environment and the fuel characteristics. The degree of lean shift and its effect on drivenbility are best evaluated in a running vehiele. Fig. 24 illusurates the observed hot lean shift and the gradual recpvery to smble condioions for three injector designs.

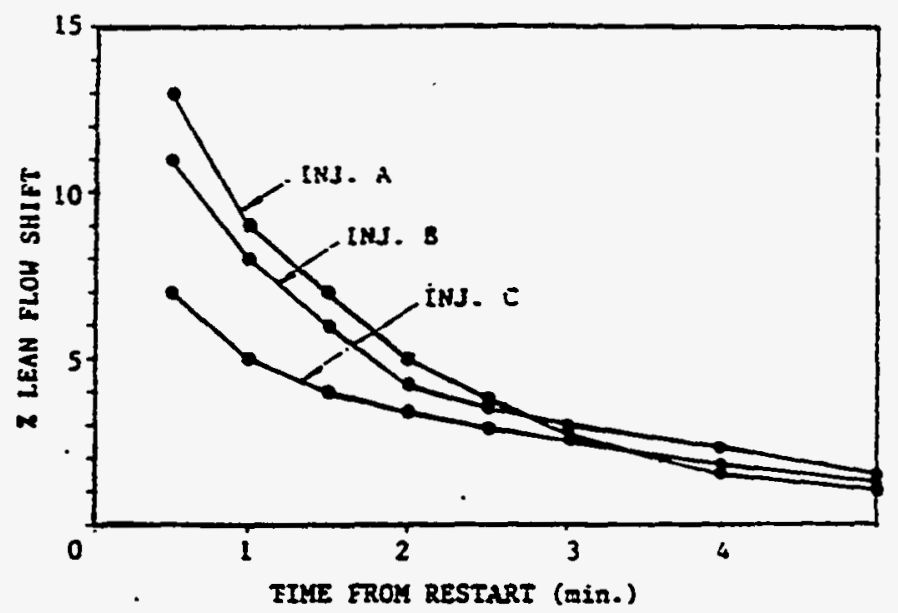

FIG. 24-HOT LEAN SHIFT

\section{Tea Erojpinent}

The purpone of this section is to provide basic information on test equipment used in mensuring fuel injecor performance characteristics according to the specifications described in Sections 4 and 3. Recommendicions are given for the design of the test flow head and hydraulic circuit for the botrom and rop feed injectorn, instrumentation resolu. tion, and diver board connections.

The tess equipment muse be capable of precisety testing various elec. tronic injector designs, preferably in mass flow units. The equipment and inseallations must be in compliance with all applicable fire and safety codes and rezulations.

6.1 Bydrmilic 3yeen-To anture thas the test stand is versazile enough to evhunte the various injecror design characteristic, the hydraulic syarem should be eaplble of operaing with n-Heptane, Indolese, and minerl spirits as specified in 3.1. The recommended hydraulic syrem plumbing dingram is shown for a boctom feed injector in Fig. 25 and for a top feed injector in Fis. 26.

The rew fuid pump must be aphble of delivering $20 \mathrm{~g} / \mathrm{s}$ of test fluid at a sable preasure of $700 \mathrm{kPz}$ to the inlex of each injector. The test fluid filtering spreem must be $3 \mathrm{\mu m}$ abolute or bester. The test stand muse be equipped with a beas exchnoger to atare that the test fluid temperzure is mincained comseane wikhin $\pm 1^{\circ} \mathrm{C}$ throughout the est. To asure that the required socurag to mesure injector performance is met. the rext fluid presture repulacion ngrem must be capable of controlling the iniet rest fluid preware to the injector inlet with an accuracr of $\pm 0.10 \mathrm{kPa}$ in the sange of $4000300 \mathrm{kP2}$. To eliminate anv effect of the fluid head on injector iniet presore, the pressure measurng dewce should be mounted in the same borizoand plane as the injector inlex. To munimize the effece of fuid presure pulations caused by the 
purap, the tex seand hydratic system must inctude an air dampened flow head. The trapped air tex head for use with botrom feed injectors is shown in Fig. 27 and thas for the top feed injecrors in Fig. 28. The trapped air pocket must be precharged to maincin a minimum air vol. ume of $\$ 0$ ce at fuel system pressure.

Table 4 summarizes the test equipment resolution required to achieve the desired accuracy of the reported date and control variabies.

6.2 Electrien/-The wiring diagram for the injector, injector drive 5., and power supply is shown in Fig. 29. Because of the different injec. Or drivers used in the automotive industry, it is recommended that the :est stand be equipped with an interehangeable (plug-in) type driver beard, $4-1 / 2 \times 6-1 / 2$ in with the numerics on the component side (see $\because 5,30)$.

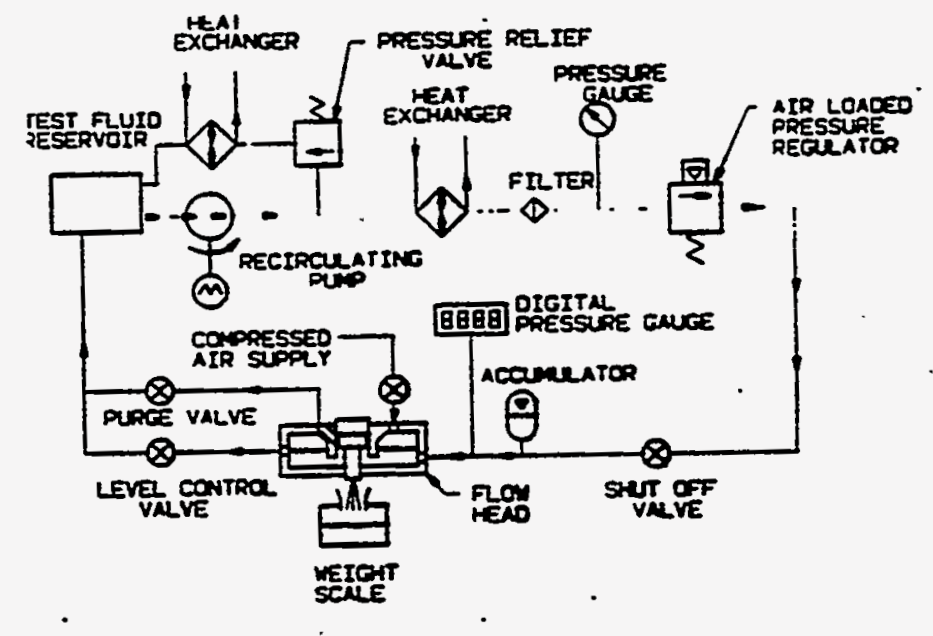

FIG. 25-HYDRAULIC SCHEMATIC FOR BOTTOM FEED INJSCTOR

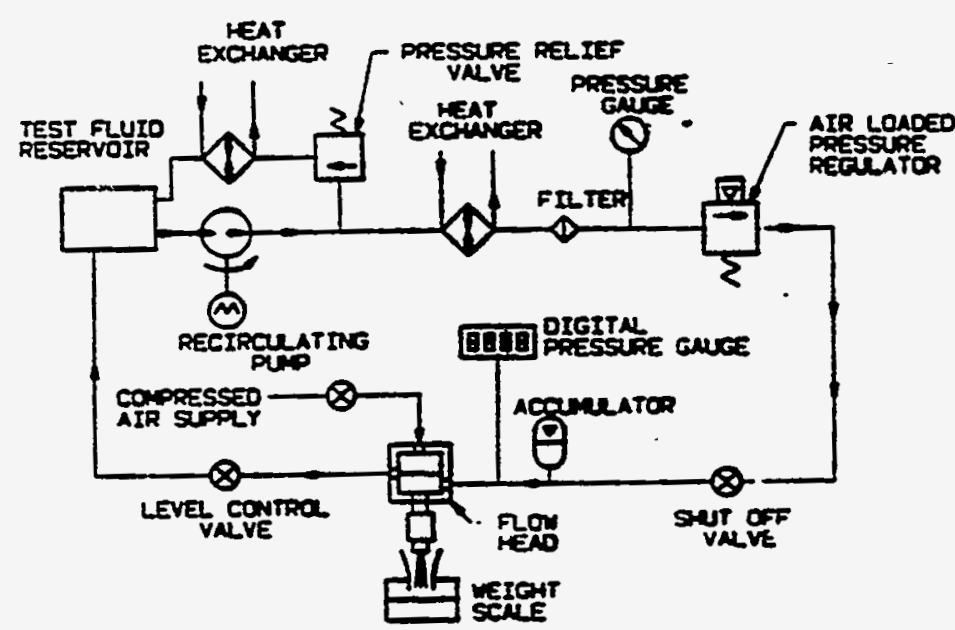

FIG. 26-HIDRAULIC SCFEMATIC FOR TOP FEDD INJECTOR

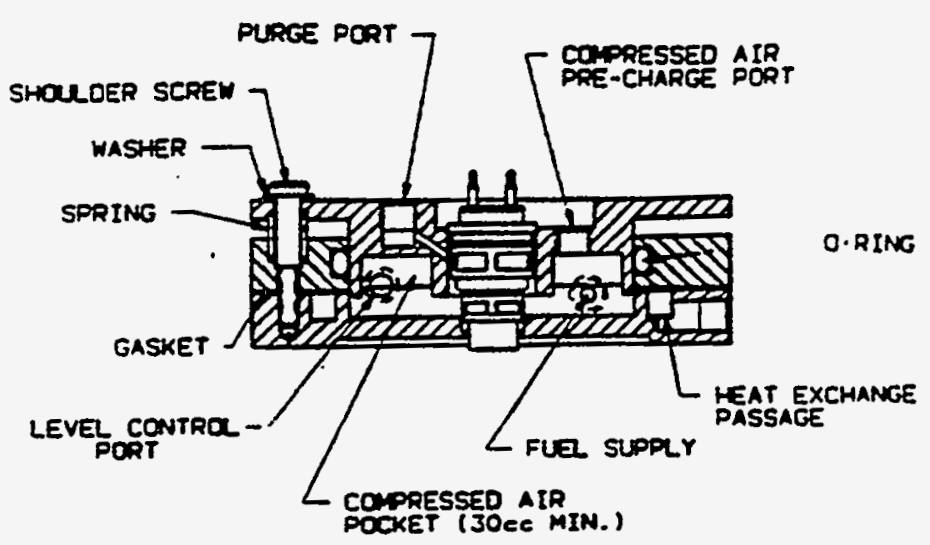

FIG. 27-BOTTOM FEED INJECTOR TEST HEAD

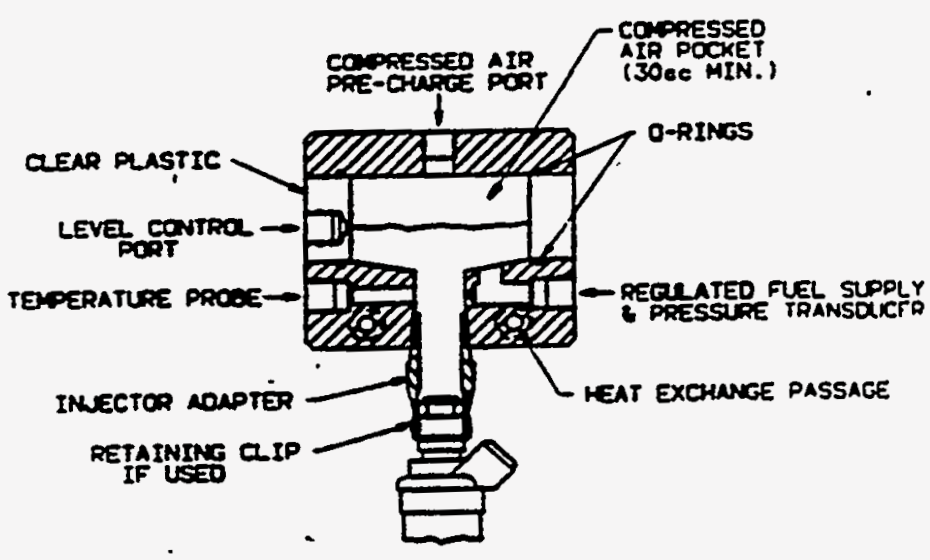

FTC. 28-TOP FEDD INIECTOR TEST HEAD

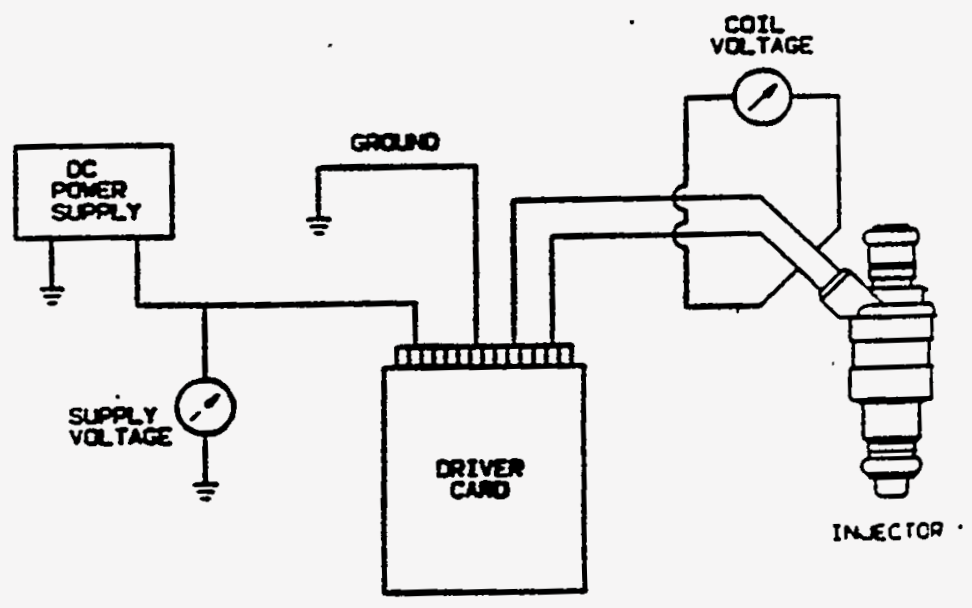

FIG. 29-ELECTRICAL WIUNG DIAGRAM FOR FUEL INJLCTOR TESTING 


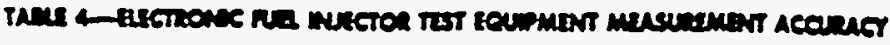

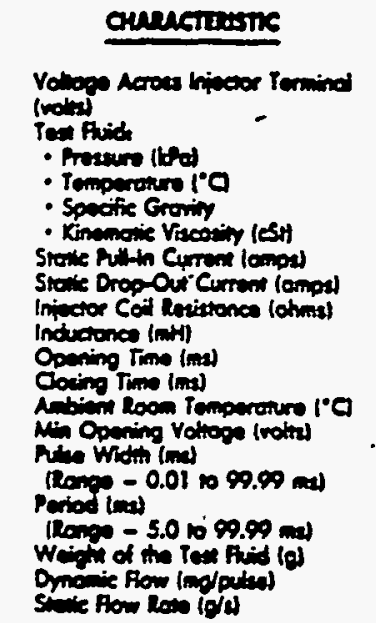

\section{raporto}

extotinow

$x \times x \times$

$x x x, x$

$x . x \times x$

$x . x \times x$

$x . x x$

$\underset{x \times x}{x . x x}$

$\underset{x \cdot x x}{x . x}$

$\underset{x . x x}{x . x x}$

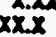

$x_{x, x x}$

xxix

$x \times x \times$

$\underset{x=x}{x=x}$

$x \times x=0$

\section{equmert}

coumon

$\operatorname{con} x$

$=0.005$

$\pm 0.01$

$\pm 0.05$

$=0.05$

$=0.000$

$=0.0001$
$=0.01$

$=0.001$
$=0.001$

$\pm 0.005$

$\pm 0.005$

$\pm 0.005$

$=0.005$

$=0.05$

\pm 0.005
\pm 0.005

$\pm 0.005$

$\pm 0.005$

colatind
$=0.10$

$\pm 1.0$

$=30$

$=0.001$

$=0.001$

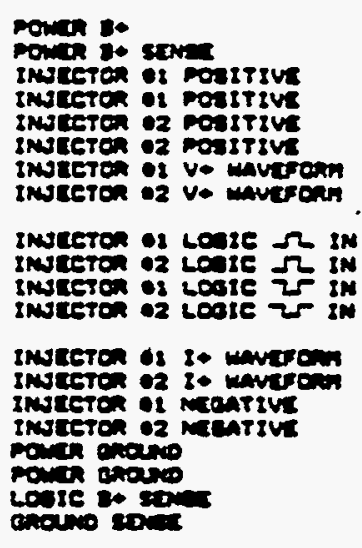

rom $\mathrm{B}$ twictor es postrive INWLTor ez rositiv In

twitcoton 18 tote $\Omega \mathrm{in}$ INLeton az Lone $\Omega$ IN ingtero os Lonie 25 8

moin anase

anouno esing

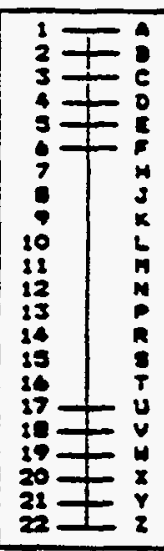

porat a.

Poun e.

IMIETOR ol montrive

INJtetor os polstive

invetes is mostrive

inuteton al motrive

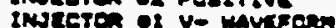

inweter es vo waviforon

Lone rever

Lonie anown

Loore anouns

Losie ancum

imiteton ol is mursonn

susteton o2 I- muvean

switeren os mentsv

INTtCTE of mentru

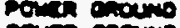

priph ancum

Losis so

nores entron

prim $x=y$

FIG. 30-INJECTOR DRIVER EDGE CONNECTIONS

\section{FUEL INJECTION SYSTEM \\ FUEL PRESSURE RECULATOR AND PRESSURE DAMPER - SAE J1862 FEB9O}

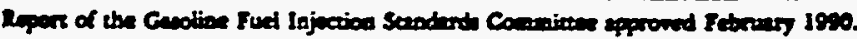

Formant-A fuel presare regulator in an electronic fuel injection strem is located downutream of the injectors and mainesins a conarolled differential presnure acroen the injectors for all engine operaing cooditions. Fuel delivered to the engine is merered by the length of time the injector is open and the controlled differential presoure. Typial fuel injection systems are hhown in Figures 1 and 2.

The moct commonly used presure regulator is 2 hydromechanial bypass pressure relief device thas is cupable of sealing the fued from ro aurning to the fuel ank when clowed. Typical fuel prespure regulators are shown in Figures 3 and 4 . The regulitor consines of pwo chnmbers separnted by a diaphragm. The fuet chamber conenins a fuet inles, a fuel outer, and a valve. The air chamber contains a mring and is usuat

\section{SAE Recommended Proctice}

ly referenced to the presure condition of the diecharge side of the in jector(s). When the fuel presaure exceeds the sex point presoure, the diaphragen rives the vatue off the sens of the curles pasenge and the exces preature is retieved by permitcing fuet to flow back to the fuel ant The actul fored sprem prevere an devilue from the desired val. we twe to an accomulation of the following ffects: slope, repeatability. hrsteresis, response accursc 10 a reference prewure sigmal, and pro ducton variabiling from regulator to regulator. Figure 5 illuserates the retawonship of the fuel presure to the manifold presure.

Several oeher types of regulators have been developed but are gener. alt used to correct a sreem problem such as the aced for dual svstem prevare or the need to excend the dymic range of the fuel system. 
Public reporting burden for this collection of information is estimated to average 1 hour per response, including the time for reviewing instructions, searching existing data sources, gathering and maintaining the data needed, and completing and reviewing the collection of information. Send comments regarding this burden estimate or any other aspect of this collection of information. including suggestions for reducing this burden, to Washington Headquarters Services, Directorate for Information Operations and Reports, 1215 Jefferson Davis Highway, Suite 1204, Arlington. VA 22202-4302, and to the Office of Management and Budget, Paperwork Reduction Project (0704-0188), Washington, DC 20503.
1. AGENCY USE ONLY (Leave blank)
2. REPORT DATE
3. REPORT TYPE AND DATES COVERED
September 1995
Final Phase 2 Report: September 1994-September 1995

\section{TITLE AND SUBTITLE}

Development of a Dedicated Ethanol Ultra-Low Emission Vehicle (ULEV)-Phase 2 Report

\section{FUNDING NUMBERS}

(C) YAW -3-12243-01

(TA) FU521010

\section{AUTHOR(S)}

L.G. Dodge, G. Boum, T.J. Callahan, D.W. Naegeli, K.R. Shouse, L.R. Smith, and K.A. Whitney

\section{PERFORMING ORGANIZATION NAME(S) AND ADDRESS(ES)}

Southwest Research Institute

P. Drawer 28510

San Antonio, TX 78228-0510
8. PERFORMING ORGANIZATION REPORT NUMBER

DE95013145

10. SPONSORING/MONITORING AGENCY REPORT NUMBER

NREL/TP-425-8195

1617 Col Renewable

Golden, CO 80401-3393

\section{SUPPLEMENTARY NOTES}

\section{2a. DISTRIBUTION/AVAILABILITY STATEMENT}

National Technical Information Service

U.S. Department of Commerce

5285 Port Royal Road

Springrield, VA 22161 12b. DISTRIBUTION CODE

UC-1500

\section{ABSTRACT (Maximum 200 words)}

The objective of this 3.5-year project was to develop a commercially competitive vehicle powered by ethanol that can meet California's ULEV standards and equivalent corporate average fuel economy energy efficiency for a light-duty passenger car application. This report summarizes the second phase of this project, which lasted 12 months. It documents two baseline vehicles, the engine modifications to the original equipment manufacturer engines, advanced aftertreatment testing, and various fuel tests to evaluate the flammability, lubricity, and material compatibility of the ethanol fuel blends.

\section{SUBJECT TERMS}

Alternative fuel vehicle, ultra-low emissions, engine modifications, equivalent corporate average fuel economy, light-duty passenger car

\section{2}

16. PRICE CODE

\begin{tabular}{|l|l|l}
\hline $\begin{array}{l}\text { 17. SECURITY CLASSIFICATION } \\
\text { OF REPORT }\end{array}$ & $\begin{array}{l}\text { 18. SECURंTY CLASSIFICATION } \\
\text { OF THIS PAGE }\end{array}$ & $\begin{array}{c}\text { 19. SECURITY CLASSIFICATION } \\
\text { OF ABSTRACT }\end{array}$
\end{tabular}

NSN 7540-01-280-5500

Standard Form 298 (Rev. 2-89) Prescribed by ANSI Std. Z39-18 